Portland State University

PDXScholar

$11-1972$

\title{
The 1972 cigarette tax referendum: a mass communication campaign
}

Gwendolyn Moore Danielson

Portland State University

Follow this and additional works at: https://pdxscholar.library.pdx.edu/open_access_etds

Part of the Health Communication Commons, Mass Communication Commons, and the Speech and Rhetorical Studies Commons

Let us know how access to this document benefits you.

\section{Recommended Citation}

Danielson, Gwendolyn Moore, "The 1972 cigarette tax referendum: a mass communication campaign" (1972). Dissertations and Theses. Paper 1557.

https://doi.org/10.15760/etd.1556

This Thesis is brought to you for free and open access. It has been accepted for inclusion in Dissertations and Theses by an authorized administrator of PDXScholar. Please contact us if we can make this document more accessible: pdxscholar@pdx.edu. 
AN ABSTRACT OF THE THESIS OF Gwendolyn Moore Danielson for the Master of Science in Speech presented November 21, 1972.

Title: The 1972 Cigarette Tax Referendum: A Mass Conmunication Campaign. APPROVED BY MEMBERS OF THE THESIS COMMITTEE:

Alfyed L. Sugarmân, Chairman,
Frank Robetrts
Theodore L. Grove

Larry A. Steward $x$

Earle H. MacCannell

During the past forty years, Oregon voters have approved oniy two tax proposals; both taxes on cigarettes. The subject of this study is the campaign carried out by proponents of H.B. 3064 to pass the most recent Oregon tax referendum measure. Central to the questions asked in the investigation of the 1972 cigarette tax campaign was why the outcome of this proposal was successful. The thesis hypothesizes that the critical variable was the involvement of major socio-economic interest groups in formulating and disseminating persuasive campaign messages.

The rationale for entering into such a study was the shortage of information on campaigns which focus not only on the effects of the "new politics" on the electorate, but which fill in details of significance 
to the historical setting within which the campaign takes place. Further, there is an apparent shortage of information on state-wide referendum campaigns which describe the campaign setting, the structure of the decision. making organization directing the campaign effort, and the voters reaction to campaign strategies.

For these reasons two research methods were utilized for the descriptive case study: a field investigation and a two-part opinion survey. The former traced the historical-political situation in Oregon, action taken by the 1971 legislative assembly to correct the state budgetary dilemma, the mobilization of public and private individuals following the successful referral drive to place the cigarette tax on the ballot, and campaign strategies carried out during the 40 day period prior to the special election.

By reviewing all available news reports and interviewing those persons active in the campaign, the field investigation revealed that the state was indeed threatened by budgetary crisis and that the proposed tax was the only immediately available solution. An alternative source would have required another special session, another 90 day waiting period, and the threat of another referendum. Without the tax, state agencies depending for support on revenue coming from the General Fund would face a two percent cut in funds for the $1972-73$ fiscal year.

It was al so found in the field investigation that the cigarette tax had support from legislative leaders of both political parties; a collection of large permanent interest groups; and an array of state officials and private citizens with pocket-book interest in passing the ballot measure. Persuasive appeals developed by the involved groups focused on the fiscal impact of a tay defeat on these and other special economic 
groups in Oregon.

Results of the second research method, the voter-leadership survey, indicated that the voters surveyed were generally accurate in assessing the participation of interest groups and were influenced by those groups most visible and state officials most vocal. It also revealed that while the voters professed to being influenced by certain groups or individuals, the reasons they gave for their vote choice were not those emphasized by the influence sources.

The leadership survey found that interest group leaders were somewhat more accurate than legislators in ascribing motives to the choices voters made, but that there was a significant discrepancy between opinions of voters and opinions of the state leadership relevant to the reasons people roted as they did.

As to the central question of this thesis, the investigation did confirm the proposition that interest groups made the difference in the success of the 1972 cigarette tax measure. Interest groups were effective, chiefly because of the many roles they performed in each phase of the campaign: as initiators of campaign activity, as legitimizers, as fund raisers, and as channel sources for disseminating persuasive messages to both their own members and to the general public. The study strongly suggests that it was the mediating activity of state and local influentials, through the mechanisms of special interest pressure and cause groups which provided the critical margin in the vote outcome. 
THE 1972 CIGARETTE TAX REFERENDUM:

A MASS COMMUNICATION CAMPAIGN

by

GWENDOLYN MOORE DANIELSON

A thesis submitted in partial fulfillment of the requirements for the degree of

MASTER OF SCIENCE

in

SPEECH

Portland State University

1972 
TO THE OFFICE OF GRADUATE STUDIES:

The members of the Comnittee approve the thesis of

Gwendolyn Moore Danielson presented November 21, 1972.

Alfyed L. Sugarmay, Chairman
Franly Roberts

Theodore L. Grove

Larry A? Steward

Earle H. Macdannell

APPROVED:

Robert W, Vogejang, Hegf, Department of Speech

David D. C1ark, Dean of Graduate Studies

November 24, 1972 


\section{ACKNOWLEDGEMENTS}

To John, Danette, David, Richard, Al, Frank, Ted, Larry, Earle, Bob, Gib, Bonnie, Brad, Robert, George, Ron, Tom, Dick, Bill, Alton, Jake, Jack, Jason, Ed, Ron, and our Electorate. With gratitude. 
TABLE OF CONTENTS

PAGE

ACKNOWLEDGMENTS . . . . . . . . . . . . . . . . . .

LIST OF TABLES . . . . . . . . . . . . . . . . . vi v vi

LIST OF FIGURES . . . . . . . . . . . . . . . . . . . . vii

CHAPTER

I INTRODUCTION . . . . . . . . . . . . . 1

Rationale ............... 3

Proposition ................ 8

Procedures ............... . . . 13

II SETTING . . . . . . . . . . . . . . 24

Recent Tax Measures . . . . . . . . . . 32

Contemporary Fiscal Situation . . . . . . 38

III CASE STUDY .................. 46

Chronology of Events . . . . . . . . . . 4 46

Formal Pressure Groups .. . . . . . . . . 48

Referendum Drive .............. 49

Special Session Convenes .......... 51

Mobilization Activity .......... 53

State Campaign . . . . . . . . . . 59

IV CASE STUDY CONTINUED . . . . . . . . . . . 82

Public Sector Mobilizes . . . . . . . . 82

Endorsements .............. 101

The Opposition . . . . . . . . . . . 112 
The Campaign Heats Up . . . . . . . . . . . 114

Post Election Reaction . . . . . . . . . . 122

V THE SURVEY ................... . . . 137

Benton and Douglas Counties . . . . . . 138

Voter Survey ............... 140

Survey Findings . . . . . . . . . . . 142

Survey Conclusions . . . . . . . . . . 170

VI CONCLUSTON ................. 175

Summary ................. . . . 175

Conclusions . . . . . . . . . . . . 180

BIBLIOGRAPHY $\quad$. . . . . . . . . . . . . . . . 190

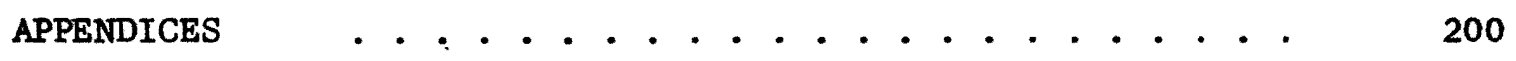




\section{LIST OF TABLES}

TABLE

PAGE

I Effects of Defeat of Tax Measure on Major

State Programs . . . . . . . . . . .

II Kennedy Poll Results on Issues: Combined

Best Reasons for Voting For and Against . . . . 74

III Validation Scores on Voter Survey . . . . . . . 141

IV Population Distribution of Survey Sample . . . . 143

V Attention to Political Messages . . . . . . 146

VI Fiscal Impact on Voters in Each County . . . . . 149

VII General Attention to Media in Each County . . . . . 154

VIII Influence Channels Related to Yes-No Vote . . . . 157

IX Personal Influence Sources . . . . . . . . 159

$\mathrm{X}$ Kanking of Group Influence ............ 161

XI Leadership Roles and Tasks Performed in Campaign . 164

XII Leadership Opinions in Influential Information

Channels and Groups ............. 166 


\section{LIST OF FIGURES}

1 Editorial Cartoon, "Spare that Tree," Oregonian, November, 1971 . . . . . . . . . . . 52

2 State Campaign Decision Making Structure . . . . . 62

3 Editorial Cartoon, "What Goes Up," Oregon Journal, December 29, 1971 . . . . . . . . . . 98

4 Anti-Cigarette Tax Brochure ........... 116

5 Editorial Cartoon, Oregonian, "The Voters of Oregon Have Decided," Oregonian, January 19, 1972 . . . 123 
GHAPTER I

\section{INTRODUCTION}

The morning papers of January 19, 1972, served notice that the cigarette tax proposal, House Bill 3064, had passed by the narrow margin of two percent. Of the 36 counties in the state, only 12 had approved Oregon's newest tax increase. For the people involved in the campaign this meant the culmination of 40 days of intense activity. If the "yes" vote did not indicate an overwhelming popular mandate, it was still hailed by the proponents as a significant victory.

From 1930, to 1971 , a period of 41 years, only one other tax measure of any kind had been accepted by Oregon's electorate. This was the 1966 cigarette tax, imposing the original four certs a package tax; passing only after four previous unsuccessful attempts. Moreover, a variety of sales tax measures had been turned down on five different occasions, the most recent in 1969 by an eight to one margin. Income tax packages had also been rejected by the people twice during the same 41 year period; and a constitutional amendment allowing the legislature 2 to impose an emergency clause on tax legislation was substantially de3

feated. It is not hard to see why Oregon voters are regarded as stubbornly resistant whenever a new tax is at issue.

The question naturally arises--why was the outcome of the cigarette tax election different? What were the features unique to the campaign? From the first organizational meeting through the implementation 
of strategies, the campaign took place within only 40 days. Some political observers commented that had the campaigners had more time to mobilize their human resources the margin of victory would have been even greater. And yet, public opinion polls conducted in late December, compared with those carried out three days before the election, showed a significant downward trend: 51 percent favoring the tax in December, and only 32 percent by mid-January.

Reports on campaign expenditures from the Office of the Secretary of State provide still another element in the puzzle. Opponents of the measure spent a total of $\$ 54,800$, while those in support spent $\$ 29,363$. It has become a truism in American politics that large "war chests" are essential to campaign victory. The losing side outspent the victors by nearly two to one, suggesting that other factors were at work.

The campaign managers attempted to explain their success by citing careful utilization of funds, explaining that nearly all of the money donated by supporters went into heavy media advertising in the metrom politan area of Portland. Yet the voters abstract reveals that adjoining counties, where all were exposed to residual metropolitan media (television and radio primarily), had starkly contrasting voting patterns. Benton county supported the tax by two to one, while Lincoln and Linn counties defeated it, albeit by narrow margins. Further, four of the twelve counties registering a positive vote were northeast and eastern Oregon counties far from any measurable exposure to the Portland television and radio stations.

Campaign success was al so attributed to heavy door-tomdoor campaigning by college youth. But student leaders themselves have reported 
practically no activity of this nature. Personal contacts were made but only to other students or faculty members in higher education in10 stitutions.

One last observation central to the questions asked in this thesis has to do with the unusually wide support by special interest groups; who, on past tax measures, have been at odds. Elections Division reports reveal that funds came from 1 abor, business, elementary-secondary and higher education sources, as well as from a wide variety of private 11

interests. If pocket-book commitment is any index of political interest--then this measure seems to have had the attention of every major occupational group in the state. It may be that the financial commitment of organizations dovetailed into political activity by members which had some effect on the vote outcome. It may also be that monetary support indicates nothing more than leadership support and is not representative of the membership at large.

Whatever the answers we know that too often political analysts have been proven wrong when they attempt to second-guess the electorate. This study is undertaken in an effort to obviate the problems of analysis by bringing together the full range of campaign activity, leadership opinion, and voter perceptions within the situational context of Oregon in the seventies.

\section{RATIONAIE}

Traditional rhetorical studies have lately come under attack because of their too frequent focus on public address as the "rhetoric of political campaigns." 12 With the advent of modern technology, 
public speeches have become relatively unimportant as devices in mass persuasion; replaced by printed and electronic mediums capable of carrying the message to far greater numbers of people. Sociologists likewise criticize descriptive studies because they provide too little in the way of soundly based evaluative judgments. Strengths of descriptive investigations are overshadowed by insufficient information regarding voter effect. Recent approaches to campaign communication use the techniques of empirical investigation to fix on combinations of a "few variables without any accompanying sense of their importance or of their ability to explain the vote-decision process."

Attempts have been made to resolve some of the more persistent shortcomings of past research. Lazarsfeld pioneered panel studies of voter behavior, and sought to explain mass communication effects in terms of informal social relationships. The resulting body of theory became increasingly well defined as the investigators focused primarily on the receiver in the communication continuum. To Lazarsfeld and those who continued his work, the central question was whether external factors such as "advertising or another person's advice" could be traced to a decision made by a particular voter. The results of the personal influence studies did expand our understanding of the effects of mass communication on voter behavior, but with only a few exceptions, it provides scarcely any information relevant to the communication process from the campaigner's point of view. 16

The social relations research paid little attention to setting. Further, the studies measured only effects of consumer, informational and partisan campaigns. Whether the theory can account for effects in 
a campaign directed at "selling" the public something as impersonal and complex as a new tax has been challenged.

Local and state referendum elections are considered unique. Existing studies do not account for campaign effects in the state or local referendum campaign for two reasons: (1) Partisan identification is the same for all voters. National research on partisan campaigns has revealed that approximately four out of five people base their final vote decision on partisan loyalties. Those with weak party identification depend for their choice on cues about the candidate's personality, or "image." Taken together, campaigns for public office assume that issues, personalities and parties are the basis for voter decision. (2) In the referendum there is only the issue; and it has been found that voters pay minimal attention to anything but the most general of 18 issues. For instance, voters may dislike taxes but have scant understanding of the way in which their tax dollar is spert. Therefore, campaign coordinators feel that the referendum campaign must be geared not only to persuading the public that the measure is in their best interest, but must attempt to educate the public as well.

Another problem with scholarly studies of political campaigns is that the majority have focused on campaigns at a national level. Equivalent analysis of state or local elections is rare. "In these elections, far more common than presidential contests, the campaign can be expected to have greater effect." 19 The reason is that on a national level appeals are directed to a differentiated mass, predicated on the early mass comranication theory of stimulus-response conditioning. At the local level it becomes possible to structure appeals to discreet 
groups, or voting blocs.

For these and other reasons, most analyses of campaign effects do not provide the communication scholar with answers as to why certain referendum campaigns succeed while others fail. Nor do institutional leaders who actually participate in political life provide accurate information on cause-effect. We know that too often they have been proven wrong when attempting to second-guess the electorate. Those closely involved in a campaign frequently possess personal theories about voter behavior that obscure the multivariable factors entering into voter choice on a specific issue in a given election year. Perceptual selectivity dictated by special interests and past experience may trick leaders into thinking they know "why" an election came out the way it did.

Group influences play a part in the "optical illusions" that develop between the elites' view of what the mass believes, and what they really do believe. Most state officials and organizational leaders spend the majority of their time in informal communication about politics with others in the same select group. Rarely do they encounter a conversation in which their assumptions of voter ideas is challenged. Studies comparing leadership perceptions with the electorate repeatedly confirm the unreliability of election cause and effect determinations based on leadership opinion.

Since the subject of this investigation involves a complex campaign waged and won in an equally complex social environment, it seemed unlikely that the questions posed could be answered by utilizing only one research method. A campaign is defined as the activities of an 
individual or group (the campaigner), in a particular context (the campaign setting), designed to manipulate the behavior of a wider

number of people (the audience) to the campaigner's advantage. . Using this definition it becomes important to consider the variables that intervene between the source and the receiver, because, as Schramm says, "it is dangerous to assume any simple and direct relationship between a message and its effect without knowing all the other elements in the process."

Therefore, as a preliminary step in an area where explicit information on state referendum campaigns is lacking, this study is undertaken primarily to obtain detailed descriptive data. We need to know: (1) the history of tax measures in Oregon, the events that led to a referendum on the cigarette tax, and the implications of action taken by the 1971 special legislative assembly in view of the successful referal of the tax; (2) the mobilization of public and private individuals and groups, the techniques they used to influence the electorate; and (3) the voters reaction to issues, appeals, and general campaign strategy. In order to gather information that focuses on each of the elements in the cigarette tax campaign (the setting, the campaigners, and the audience), it was felt that a two-part case study was required that utilized both the field investigation and survey research methods. Such an account of the events under investigation will provide information whe reby: (1) reconstruction of a state-wide contemporary referendum campaign can be built, (2) certain inferences regarding the nature of communication in such campaigns can be drawn, and (3) questions relevant to success or failure of campaign strategies can be answered. 
In summary, methods employed may provide evidence that can become part of a realistic analysis of the process that James Bryce referred to as "the mutual action and reaction of the makers or leaders of opinion upon the mass, and of the mass upon them." ${ }^{24}$ Campaigns that precede democratic elections function not only to persuade the voter of the value of leadership judgments on the course public policy should follow, but values and attitudes held by the public have an opportunity to surface when they would not under ordinary circumstances. In a democracy it is the campaign which draws attention to the reciprocal relationship between state leaders and the citizenry.

\section{PROPOSITION}

Herbert Bauss and William Ross, owners of a well known California public relations firm, have written that in elections won by a close margin in various parts of the nation, it has of ten been the activity of groups like public employees that made the difference. In observing past Oregon referendum campaigns, the writer's own observations tend to confirm the importance of interest group activity in the outcome of elections. The very nature of Oregon's initiative and referendum procedures seem to require such activity; both in initiating a ballot measure and in doing the work necessary to pass it.

More often than not, such interest gruups work against each other. The 1966 Tax Limitation measure, for instance, was initiated by a group called the Oregon Homeowners Association. Once the measure was placed on the ballot, groups representing business and education, among others, joined together in a campaign to defeat it. In the 111 fated 1969 Sales 
Tax measure, business interests pushed its passage in the legislature and upon referral to the people, attempted to organize other groups in support. Their attempts failed as the large AFL-CIO organization mobilized locals around the state in a successful campaign to defeat the tax.

Given the accuracy of Bauss and Ross's observation regarding the importance of employee groups in a close campaign, and the historical nature of campaign support in Oregon, this investigator wondered what might happen if major interest groups collaborated in their campaign activity. Preliminary investigation suggested that a large number of groups were involved in the cigarette tax campaign, groups with existing mechanisms for disseminating information to their membership; as well as temporary cause groups which formed for the specific purpose of working in behalf of the tax increase. As a result, it was decided that an investigation of the relationships of campaign activity that existed between interest groups might reveal important contributing factors in the out come of the election.

The preceding overview of the political situation that existed in Oregon in late 1971 and early 1972, suggests that the proposed tax increase faced a high probability of defeat. The introductory comments also stated that causal rel ationships are not reajily forthcoming. In an effort to establish such relationships, therefore, it is the hypothesis of this thesis that the critical variable in the success of the 1972 cigarette tax campaign was the involvement of major socio-economic interest groups. The specific purpose of the thesis then, is to test the hypothesis so that certain generalizations can be made regarding 
the nature of participant involvement in a state referendum campaign.

Interest group as it is used here denotes either a permanent pressure group composed of individuals who join together beca:se of a specific social or economic long-range interest, or temporary cause groups whose members are attracted because of a common interest in a short-term issue. Pressure groups are characterized by their formal organizational structure and permanence while temporary cause or promotional groups may disband once they perceive the objective has been achieved or have determined that it has no chance of attainment.

The thesis argues that all social action can be evaluated in terms of the flow, structure and content of communication. In order to assess the communicative processes of interest groups and the nature of their involvement, the inquiry will exmine their activity in each of the three phases of communication.

First, we will contend that interest groups $c$ an be viewed as channel sources for the dissemination of information (communication flow) to their members. Channel source is defined as the means by which messages flow from the advocate source to the intended receiver, in this case, the source is the state campaign coordinator who utilizes existing organizations as vehicles to relay the arguments to the public. In general terms, a channel may be of two classes: (a) secondary channels in which messages move indirectly to the receiving source with no possibility of immediate feedback, as in televized propaganda or public speeches; and (b) primary channels utilizing the interpersonal medium with its attendant source-receiver interaction. Membership refers to the uninvolved and initially uninformed individuals belonging to an 
interest group, who depend on the group leadership for their "definition of the situation." Leadership identifies for these members group goals, provides information relevant to the issue, and attempts to influence group opinion.

Second, we will examine how interest groups structure their appeals in their attempts to define the relevance of the measure to membership needs (communication content). Interest group leaders may attempt to inform, educate, or indoctrinate members by using either factual or emotionally loaded words in designing the message. The way in which messages are ultimately composed will reflect such deliberate efforts. Finally, we will argue that endorsements made by interest groups provide a means by which specific arguments gain voter attention. Among the many possible issues that can be used persuasively, only one or two will be chosen. The argument that is used, finally, in announcing support not only provides information of a general nature, but functions to legitimize the campaign by drawing a connection between membership goals and the effects on them of the ballot measure proposal (communication structure). Endorsements may take the form of public press releases that can reach the total public; but they may also be known only to members through organizational bulletins or newsletters.

In testing the proposition the following general questions will be asked regarding the campaign itself:

1. Which individuals and groups were involved in the campaign, how did they become involved, and why?

2. What was the nature of individual and group involvement: the roles they performed and the resources they utilized? 
3. What was the perceived effectiveness of interest group activity from the frame of reference held by representative leadership?

4. Was there any coordination between groups in planning campaign strategy, decision making, and organization of resources?

After assessing actual campaign contributions by interest groups we will inquire into their impact by asking:

1. Did membership in a particular group make it more probable that persuasive communication regarding the cigarette tax issue was received favorably?

2. To what extent did the membership of a particular group look to that group for verification of an election choice?

3. How accurate are the voters in assessing the role of special interest groups in the campaign?

4. Is there congruence between what the public and private influentials believe and what the voters believe when judging the impact of a particular argument?

While the study focuses on the main question of interest group 1 participation and effectiveness in the cigarette tax campaign, it does not exclude other questions. Some of these questions are:

1. Were there people who voted in this campaign who do not typically vote in state tax elections?

2. If so, did these "seldom vote" people identify with either an interest group involved in the campaign or a particular socio-demographic membership group?

3. Did the people who by their own statements rarely cast a ballot in a state tax measure election believe they would have been affected by passage or defeat of the tax measure?

4. To what extent does the voters judgment conform to the fiscal impact identified by state influentials? 
5. In what ways do similiar demographic groups conform in their awareness of (a) issues, (b) channels used, (c) groups involved?

6. And an important question for any campaign utilizing mass cqmmunication techniques: who, finally, is the audience who listens to campaign messages?

It is virtually impossible to isolate all the relevant variables that may influence the vote outcome. But it is possible to discover deliberate campaign strategy: decisions made by coordinators such as which voters are most likely to be swayed by appeals, the issues that should be emphasized, the best means for raising funds, how to allocate personnel time, and the selection of points on which the opposition 26

seems most vulnerable. By identifying the product of these decisions and then asking a sample of voters their opinions about which appeals and issues were most important, how they obtained their information, and what the impact of the measure would be on them, the most significant factors in the election should become clear enough so that a realistic estimate can be made of the campaign impact. This in turn will offer arguments either in support of, or in refutation to, the thesis hypothesis.

\section{PROCEDURES}

\section{The Field Investigation}

Part one of the research plan includes a descriptive case study of the cigarette tax campaign, beginning with its inception following the 1971 legislative special session through the post-election week. The purpose of the field investigation was to reconstruct impor- 
tant aspects of the state referendum campaign. The exploration sought to establish who (the campaigner) said what (the message) to whom (the audience) by what means (the channe1) and to what effect (behavior of the receiver). In other words, the field investigation examines the campaign in terms of the communication flow.

Information was gathered in three ways: (1) through open-ended personal interviews and correspondence with relevant information sources, (2) by utilizing available news reports about the campaign, and (3) through analysis of campaign messages directed to the electorate.

Interviews and Correspondence. Principal campaign coordinators were interviewed as well as leaders within each major interest group which played a role in the campaign. Some of those contacted were the professionals paid to coordinate the campaign, leaders from the Oregon School Employes' Association, Oregon State Employes' Association, Oregan Education Association, Associated Oregon Industries, representatives from higher education, and organized labor. Representatives from government agencies who publicly spoke out on the issues comprised another class of interviewees, as did legislators who endorsed the tax measure through personal appearances and press releases. Each time an interview revealed the name of a group or individual connected with the campaign, every effort was made to contact that person. In this way the net of communication gradually expanded to include every organization active in any significant way throughout the state.

Appointments for the interviews were obtained by phone and in each case were conducted in the informant's office. The responses were recorded on tape and afterwards transcribed sequentially and without inter- 
pretation. They were begun shortly after the January $18 \mathrm{th}$ election and continued through June of 1972 .

When interviews were not fossible, letters were sent to organizational representatives or to legislators. The letters requested pertinent information related to the individual or group's specific function in the campaign as well as any other information deemed possible from that source.

A sample of the questions put to the formal leadership is included in Appendix B. They were designed not only to obtain retrospective accounts of situations and events but also for opinion and perceptual content. All of the interviews conducted in person and by letter included such questions as:

1. The identity of individuals or social systems engaged in the selection and dissemination of messages.

2. The roles played by individuals in decision making strategy, issues chosen, design of the messages, themes and slogans, channels utilized, and timing of campaign strategy.

3. The coordination of campaign efforts between interest groups and cause groups or apparent lack of cooperative effort.

4. The evaluations made at any time regarding the effect of specific message flow or issue appeal. Also, the presence of any feedback provisions and their impact on future decisions.

5. The aspects of the campaign perceived as most effective: selection of appeals, activity of interest or ad hoc groups, or strategy decisions.

Other questions varied, depending upon the individual being interviewed. In the case of Jack Thompson, Assistant Secretary of State, opinion on general campaign effectiveness was solicited because he is 
not only a long time observer of Oregon political events but because he was uninvolved yet intimately aware of campaign strategies. Ted Hallock, on the other hand, is familiar with Oregon politics both as a state senator and as a professional public rel ations executive who was not only closely involved in the campaign but directed much of the formal activity. In sum, questions posed in interviews and by mail were both general and highly specific depending on the interviewer's judgment as to the best way to obtain the greatest amount of information.

News Reports. Accounts of the campaign were collected from published reports of the events covering the period from December 16, 1971, to February 11, 1972, including the student newspapers from three state universities: Portland State University, Oregon State University and the University of Oregon. Newspapers published in each Oregon county were collected covering the same period and an analysis made of their contents: editorials, letters to the editor, regular news reports and feature columns. The newspaper files were a compilation of all releases obtained by the Governor's office, the Oregon State Employes' Association, Oregon Education Association, and Oregon Department of Human Resources through the services of a professional clipping agency.

Campaign Messages. Press releases, radio and television copy, organizational bulletins and campaign "fliers" were the third source of research data. Whenever possible this material was obtained directly from the diffusion source, i.e., the organization writing and distributing the material. Radio and television copy was provided by Ted Hallock's public relations firm who developed it, newsletters were collacted from a 
representative of the organization distributing them, and press releases or speeches were collected whenever available.

\section{The Survey}

Strategy. Originally the research strategy called for mailed questionnaires to a random sample of Oregon voters in order to assess the effects of the campaign. That purpose was abandoned as informal conversations with campaign leaders and other interested citizens who watched the progress of the campaign revealed discrepancies in opinion regarding the "effect" of the referendum issue on the average voter. Barly interviews similarly suggested a wide divergence in opinion. It seemed more appropriate to the purpose of this study, therefore, to survey not only a segment of the voting population but also organizational representatives, involved individuals representing ad hoc groups, legislators who spoke at public meetings in defense of the measure, and newspaper editors in counties where the measure passed but where 28

there was very little direct media support. This comparison of an elite to a cross-section sample was done to obtain data for a comparative analysis of perceptions about cause-effect.

\section{Sample.}

\section{(1) Voters. Because of financial limitations it was} decided to confine the voter survey to two counties: both, as was mentioned earlier, representing areas where little in the way of publicity via mass media was evident. Douglas and Benton counties were chosen because approximately the same number of votes were cast in each. Also, since the chief objective of the survey was to discover which channels were the most effective in influencing voter behavior, the counties 
represented contrasting vote patterns: Benton, passing the measure by over 2,000 votes; and Douglas, defeating it by approximately the same 29

margin. One out of every 50 persons who voted were mailed survey questionnaires.

(2) Formal leadership. Leadership is defined as those individuals within interest or cause groups who identify group objectives for members, provide them with information concerning a particular issue, and attempt to influence group opinion. They might also be termed "general influentials," or "potential influentials," because they are representatives of their groups by virtue of formal designation: officers in professional or student organizations, and those who are employed in positions of responsibility within their professions.

Since formal leadership as defined here is largely made up of individuals in positions of responsibility, it was decided to query both institutional leaders, heads of temporary task groups, and legislators who played a role. The leaders were selected on the basis of their visibility in the campaign. The criteria used to identify them was the occurance of public statements quoted in the press and the testimony of others who knew from personal contact who had participated.

(3) Newspaper editors. Information gathered from this group was intended to provide only supplementary data and opinion concerning activity taking place in the northeast and eastern part of the state. Only editors from the small newspapers of Malheur, Umatilla, Union and Gilliam counties were queried, as well as editors from the two counties previously mentioned, Benton and Douglas. Most of the newspapers are small, with circulation ranging from 3,000 to 10,000 readers. 
Selection Procedure.

(1) Voters. Names of the voters were obtained from county clerks in Benton and Douglas counties. Only registered voters who had cast their ballots in the January election were included in an effort to reduce the number of subjects lost because they had not voted or had no interest in the referendum. A common validation problem in mail surveys is due to the subject's low motivation in returning the questionnaires. This method of sample selection was an attempt to partially alleviate the attending bias. Since a certain amount of interest is preliminary to travelling to the polls, it is reasoned that the respondents obtained in this fashion might be slightly more aware of issues and appeals used in the campaign.

The sampling method required the selection of every fiftieth name appearing next to a signature in the county poll books.

(2) Formal leadership. A survey of newspaper clippings for the period under investigation revealed the names of state legislators; and a list of formal leadership was compiled by sifting through transcripts of early interviews. The purpose was to establish a tentative state communication network as well as provide for a larger sample of elite opinion.

(3) Newspaper editors. Names of newspapers and editors were obtained from the Oregon Bluebook 1971-72. Questionnaires were mailed to every editor in the six counties representing the sample. 31 Questionnaire. The questions were developed to parallel in 
content the questions posed in the formal interviews. Questions form32

ed six general categories:

1. Validation data: pertaining to area of residence age, sex, political party, and other data used to provide a check on the sociodemographic composition of the sample.

2. Filter questions: designed to check the respondent's awareness of politics in general and this issue in particular, i.e., whether they had given any thought to the election and the issues. Also, to ascertain the extent to which they exposed themselves to sources of information.

3. Information questions: used to identify the respondent's membership affiliations and understanding of the role played by his organization; and to discover nonmembers awareness of group campaign roles.

4. Intensity questions: attempting to determine the strength of the respondent's identification with a membership group; as well as the degree of interest in political issues.

5. Explanation questions: asking "why" of an opinion or behavior.

Because of the time that had elapsed between the occurance of the event and the survey, and because of computer requirements, it was necessary to maintain the closed-end question format. Also, forcing the respondent to make a selection from specified alternatives provided data necessary to establish the degree of correspondence between communicative intention of the political elite and the behavioral effect on a cross-section of Benton and Douglas county voters. Open-ended responses were solicited as well, but because of their rambling nature, these were used only incidentally in the narrative and discussion. 
Notes

1"Evans Lauds Vote Result," Oregonian (Portland, Oregon), January 19, 1972; "Troperty Tax Cut, School Aid Hike, Go with Cigaretie Levy," Capital Journal (Salem, Oregon), January 19, 1972.

"Oregon's Emergency $\mathrm{Cl}$ ause" is a provision of the Oregon Constitution providing that when an emergency condition exists, the legislature may place the emergency $\mathrm{clause}$ on any piece of legislation with the exception of tax measures. Upon the signature of the President of the Senate, Speaker of the House and the Governor, the act immediately becomes law; otherwise an act does not become 1 aw until 90 days have elapsed after the legislature has adjourned (Articie IV, section 28); See Appendix A for abstract of recent tax referendum measures.

3"Initiative and Referendum Measures," Oregon Blue Book 1971-72 (Compiled and published by $\mathrm{Cl}$ ay Myers, Secretary of State, 1971), pp. 257-260; "Initiative and Referendum Measures," Oregon Blue Book 1959-60 (Compiled and published by Mark 0. Hatfield, 1958), pp. 224-233.

40 regon editorial writers frequently make reference to voter resistance on tax measures, as do historians and political scientists when reviewing electorate behavior; see for example: "Oregon," Politics in the American West, Frank H. Jonas, ed. (Salt Lake City, Utah: University of Utah Press, 1969); Editorial, Oregon Statesman (Salem, Oregon), January 21, 1972; Editorial, Oregonian, January 20, 1972 .

${ }^{5}$ Richard L. Kennedy and Associates, "Attitudes Toward the January 18, 1972 Special Election on Increasing the Cigarette Tax," Public Opinion Survey (Eugene, Oregon), December 27, 1971. (Zeroxed)

${ }^{6}$ Brad Davis, private interview conducted in Portland, Oregon, February, 1972 .

${ }^{7}$ From records made available by the Secretary of State, Elections Division, 1972 .

${ }^{8}$ Dan Nimmo, The Political Persuaders (Englewood Cliffs, N.J.: Prentice Hall, Inc., 1970), p. 63.

${ }^{9}$ See Appendix B for counties approving 1972 tax increase.

${ }^{10} \mathrm{Alt}$ ton King, interview by telephone, June, 1972.

11 Ibid., records from Secretary of State.

12David L. Swanson, "The New Politics Meets the Old Rhetoric: New 
New Directions in Communication Research," The Quarterly Journal of Speech, Vol. 58 (February, 1972), p. 37.

13Melvin L. DeFleur, Theories of Mass Communication (New York: David McKay Co., 1970), pp. 152-153.

14 Nimmo, p. 26.

15 Bilhu Katz and Paul F. Lazarsfeld, Personal Influence: The Part Played by People in the Flow of Mass Communications (Glencoe, Illinois: The Free Press, 1955), p. 5.

${ }^{16}$ A notable exception is Shirley A. Star and Helen MacGill Hughes, "Report on an Educational Campaign: The Cincinnati P1 an for the United Nations," American Journal of Sociology, Vol. 55 (1950), pp. 389-400; but even here the chief focus is on the effects of an educational campaign.

${ }^{17}$ Bernard R. Berelson, Paul F. Lazarsfeld, William N. McPhee, Voting (Chicago: University of Chicago Press, 1954).

18 Nimmo, p. 22.

${ }^{19}$ Ibid., p. 5.

20 For a review of theories of mass communication, see DeFleur, Theories of Mass Communication; and Elihu Katz, "The Two-Step Flow of Communication: An Up-to-date Report," Public Opinion Quarterly, Vol. 21 (Spring, 1957), pp. 61-78.

${ }^{21}$ Phillip E. Converse, "Constraints on Belief-Systems of a Mass Public," in Ideology and Discontent, David E. Apter, ed., (New York: The Free Press, 1964), p. 213.

${ }^{22}$ Nimmo, p. 10.

23 Wilbur Schramm, "How Communication Works," in Mass Media and Society, Al an Wells, ed. (Palo Alto, California: National Press Books, 1972), pp. 182-185.

${ }^{24}$ James Bruce, The American Commonwealth (Macmillan, 1888), Ch. LXXVI: cited by Graeme C. Moodie and Gerald Studdert-Kennedy, Opinions, Publics, and Pressure Groups (London: George Allen and Unwin Hd., 1970), p. 27.

25 Herbert M. Bauss, and William Ross, Politics Battle Plan (New York: The Macmillan Co., 1968), p. 234. 
${ }^{26}$ Nimmo, p. 18 .

27 Bruce H. Westley and Malcolm S. MacLean, Jr., "A Conceptual Model for Communications Research," in James $H$. Campbell and $\mathrm{Hal} W$. Hepler, eds., Dimensions in Communication: Readings (Belmont, California: Wadsworth Publishing Company, Inc., 1968), p. 63; the thesis inquiry parallels Laswell's model of communication in its essentials.

${ }^{28}$ Brad Davis.

${ }^{29}$ See Appendix C for summary of county abstract; Oregon, Official Abstract of Votes: Special Election 1972 (Compiled and published by Clay Myers, Secretary of State, Elections Division, March 1, 1972), p. iii.

${ }^{30}$ Oregon Blue Book 1971-72, pp. 168-171.

${ }^{31}$ For a complete review of questionnaires, see Appendix $D$.

${ }^{32}$ Categories adapted from: George Gallup, A Guide to Public Opinion Polls (Princeton, N.J.: Princeton University Press, 1944), cited in Nimmo, p. 99. 
CHAPTER II

SETTING

Modern Oregon is a three zone country: an always green and lush Pacific coast land, an often green strip of valley, and a rarely green eastern Oregon plateau. The state boundaries and natural geographic divisions remain largely unchanged since statehood was granted in 1859 .

While Oregon's population has grown rapidly during the past 20 years, the composition retains a predominantly homogeneous cultural mix; there has never been a large ethnic community in Oregon, with clearly defined cultural ties. Immigrants from Germany, Engl and, Ireland, Canada and Scandanavian countries merged with immigrants from Ohio and Mississippi during the $1850^{\prime} \mathrm{s}$. According to Robert Burton, the population has traditionally been white, agrarian, and Jeffersonian.

For the first ninety years of statehood, blacks accounted for less than one half of one percent of the population and Mexican-Americans were so few in number as to be absent from United States census bureau figures. The pre-World War II Indian population numbered less than fou $r$ tenths of one percent--an ethnic group certainly, but one which had practically no impact on Oregon cultural or political life. Burton cites geographic isolation and a slow but steady rate of growth after 1850 for the cultural blend that characterized the old Oregon.

Today, minorities account for three percent of the population: 5 blacks, 29,308, Indians 13,410, and other non-whites, 19,488. The Ku Klux Klan, which was among the most active in the nation during the $1920^{\prime} \mathrm{s}$, 
is out, and minority studies are in.

James N. Tattersal1, University of Oregon Economics Professor, savs that "today's population is younger, better educated, more concentrated in professional and white collar occupations, and richer." Perhaps also more liberal. Less homogeneity may, according to Professor Tattersal1, lead to even more change. The "new electorate" will, in his terms:

- . demand high quality in state and local government services, particularly in education and recreation. It should, on the other hand, be more willing to levy and accept the taxes to pay for the se expanded services. ${ }^{8}$

Historically Oregonians depended heavily on wildlife industries, but since the late $1930^{\prime} \mathrm{s}$, timber production grew to become the chief source of commerce and, again, the trend is changing. Measured by "value added" figures, manufacturing increased by 63 percent while during the same period, value added by the forest products industry 9 increased only 46.2 .

Fishing was once a major Oregon industry, second only to forestry, but today the game commission keeps the major rivers stocked with, not native, but hatchery raised fish. Hence the growth of the tongue-incheek, James T. Blaine Society, whose largely fictitous membership is said to be busy posting signs on Oregon borders: "You're welcome to visit, but please don't stay."

Politically too the state is changing--from a predominantly Republican one-party system during the years between 1900-1932 to a nearly equal party registration during the late 1940 's. In 1969 Democrats led by over 100,000 , with a total of 521,662 registered voters and 
Republicans registering 410,693.

In practically every significant statististical way, Oregon in the 1970 , wears a new face. Bu: in spite of, or perhaps even paraliel to such changes, one very significant facet of the state profile remains unchanged--the political philosophy.

The state has never had an eastern style political machine manipulated by ward bosses, political hatchet men and the like. A state machine was never put together in part because of Oregon's "puritan" public attitude toward politics, and in part because politicians seemed unable to get together--under the party banner. According to one political analyst, the adoption of the direct primary in 1904 broke down what little party unity might once have existed. ${ }^{14}$ others claim. that Oregon's system of direct legislation, expressed in the primary 1 aw, but also in the initiative and referendum, minimizes partisanship. Historically each candidate waved his own flag and campaigned on his own merit, not on party. In 1934, the Portland Oregonian concluded: "Major contests are decided on the basis of personal fitness or personal popularity of the candidate. Practically the only party significance any more to an election of governor is that success enthuses the party with which he affiliates. 16 Democrats and Republicans alike appealed to the voter on the basis of popularity and issues. "An old style Democrat may look like a new-style Republican and vice versa," when they present themselves to the voters.

One only needs to observe the 1970 partisan to note that Oregon is still pos sessed of a great many candidates who pay only lip service to party. Each election year since 1960, Democrats meet for their pre- 
primary convention and set forth elaborate party platforms. The platform makes news for one day and occasionally a bold challenger will remind the voters that he, unlike the incumbent, represents best the will of the party. For the most part however, political aspirants, especially during the primary, merely pretend to conform. Some candidates have boldly discounted the party document as not being representtative, and therefore not a legitimate plank from which to campaign. Republicans too have their official platform convention, out they also have their Dorchester Conference founded by Senator Robert Packwood in 18

1963. A glance at the respective results of such conclaves reveals certain distinctive gaps in Republican performance versus Republican philosophy.

But party registration and conformity to party platform does not tell the whole story. Voters frequently register in one party and vote for candidates of the other party. For example, in the 1970 general election, Oregon voters elected a Republican governor and a Republican majority to the House of Representatives. While Democrats held a majority in the Senate during the 1971 Legislative Assembly, the Senate president was elected by the fourteen Republican members joining with two Democrats to go dramatically counter to the Democratic caucus choice. A similiar coalition of Democrats and Republicans was enlisted during 20 each of the past six sessions of the Oregon legislature.

The strength of a state Republican organization has been cited as a critical deciding factor in voter response to candidates; an organization that will work to develop candidates and work to get them elected. But as to the functioning of partisanship in the legislature, "party 
responsibility...is strictly a euphemism in Oregon."

Oregon voters retain a considerable amount of independence and the state is often and accurately characterized as a consistently inconsistent two-party state. Moreover, in political climate it is a notably "clean" state. One academic observer uses the phrase, "moralistic political culture," to describe the political atmosphere, believing that Oregon's government is predicated on the ideal of selfless community service. "Party. allegiance," quotes Burton, "takes second place to the public interest." Former Senator Wayne Morse is a case in point; switching registration not once but twice during the years he served in the United States Senate and justifying his change by saying:

No Republican party officials, state or national, ever had the right to assume that in the name of party regularity I would sacrifice my responsibility to the people of Oregon by voting party 1 ine whenever I thought
so-called party policy was not in the public interest. 24

The results of such a "moralistic culture" and relatively nonpartisan climate finds expression in the issues selected for campaign rhetoric. Rather than campaigning on the party plank as in many states, candidates for state and national office tend to campaign on issues aimed at all the people whether the issue be conservation today, or prohibition and hydroelectric power yesterday. "Principles above party," "the greatest good for the greatest number," "not for the party spoils but for the good of the country," are phrases that glitter from the pages of Oregon history books.

All of this is not to say that Oregon is an untarnished state lacking her own form of political intrigue. The peculiarity that is 
distinctly Oregon is that odd political cul ture that struggles to develop social and economic growth mechanisms while at the same time, wielding the stick of referendum and initiative, knocking out money for programs that will advance such growth. Voters may ignore partisan issues in choosing their leaders but they frequently confound those they've elected by utilizing their right to referendum and initiative.

\section{Historical View of Initiative and Referendum}

The people in Oregon can create or destroy any act. The adoption of a political system that entrusts all of the power in the people originated in a constitutional amendment passed in 1902 providing for the Initiative and Referendum.

Using the initiative, voters can submit a petition to the Secretary of State carrying a specified number of valid signatures and so place any measure on the ballot. By petition, also, any measure passed by the Oregon legislature can be placed on the ballot thus enabling the voters to sanction or defeat the measure by a majority vote. Any constitutional revision passed by the legislature likewise must be referred to the voters before it can become law. The outcome of ballot measure elections rests in the hands of a majority of those casting their ballots, not a majority of those registered. Furthermore, the Governor has no power of veto over laws passed with these methods. The legislature can later amend them, but the same process, the referendum, is at the disposal of the people and using it they can prevent any amended measure from going into effect.

The first exercise of the power of referendum was in 1904 when the Direct Primary Law was submitted to the people and carried--enabling 
any citizen anxious to participate in the political life of the state to run for office without looking to party for support.

In the election of 1908 another significant measure, the Corrupt Practices Act, was referred and passed by the people. It provided originally for a ceiling on campaign spending, prohibited electioneering on election day, and generally set forth a doctrine for political be29

havior. A number of amendments to the original act have occurred since, including the elimination of restrictions on public employee participation in politics and the elimination of the prohibition against campaigning on election day. The Corrupt Practices Act in its present 40 page form, is notable in that it retains the populist character of the original bill's intent.

By 1910 the people had adopted the Recall Act enabling a specified number of registered voters in the state or voting district to petition for an election to deterinine if the official under recall threat could continue to serve. Also adopted were the Initiative and Referendum to Apply to Local Laws Act, increasing the power of the people in deciding local policy; the Presidential Preference Primary 1aw, requiring party delegates elected by the people to cast their ballots, en toto, for the presidential candidate approved by the people in their primary elections. Among those measures initiated by the people and defeated, were the Equal Suffrage Amendment (defeated in 1906, 1908, 1910) ; ${ }^{30}$ Amendment for Single Tax; and State Wide Prohibition. All of these measures, approved and rejected, were placed on the ballot through the Initiative Law and have shaped the political destiny of the state to this day. Another constitutional provision that has added to the paradox of government is the restriction against placing the emergency clause on tax 
legislation. This section of the Oregon Constitution provides that a measure imposing a tax on the people cannot become law for 90 days 32

after the session has adjourned, having the effect of providing extra time for resourceful citizens or special interest groups to garner the required signatures to call for an election. Even if unsuccessful in defeating the tax, a referendum can usually delay implementation of a bill for nearly two years, or until the next general election. Since by constitutional $\mathrm{I}$ aw, Oregon must maintain a bal anced budget, the budget being drafted on the biennium, this clause has proved to be the source of a considerable amount of frustration to officials charged with the responsibility of maintaining a sound level of state services. To summarize then, given sufficient energy and organizational machinery, any individual or group can challenge any law enacted by the legislature. Allen Eaton, writing in 1912, described the system as an "experiment in Democracy," and said of Oregon:

It is... a state where the people can and do enact laws for the common good which their legislature has failed to enact for them, where they can nullify any obnoxious measure passed by the legislature....

It is... a state where the people can and do amend their constitution in the most radical fashion by a minority vote.., where special interests hire citizens to circulate petitions .... where one-twentieth of the voters can and do cripple 33 the state educational institutions by holding up their funds....

In 1971 another author wrote:

Oregon today has its...best tax brains proposing stopgap solutions and the people fire back objections. The whole process 34 akes time and the money situation continues to worsen. 34

Oregonians have rarely permitted a tax approved by the legislature to become law without the "second legislature," the people, first scrutinizing it by their vote. The fiscal effects of the people's power 
is one of the situational variables that is the concern of this thesis.

\section{RECENT TAX MEASURES}

It is unlikely that anyone finds pleasure in paying taxes. It is equally unlikely that anyone finds pleasure in a decline of living standards expressed through cutbacks to public agencies that service the people and their growing requirements. At the state level, Oregon voters expect the best in the way of services, but since 1930 have defeated over 82 percent of the ballot measures which included in the ballot title the word "tax."

During the past decade five referendum tax measures have been placed before the people for decision: the 1960 Personal Income Tax, 1963 Personal and Corporation Income Tax Bill, the 1966 Cigarette Tax, the 1969 Sales Tax and the 1972 Cigarette Tax. Of the five, only the two cigarette tax proposals were apprcved. Those referred since 1966 are of particular importance here, because of their similarity to the 1972 cigarette tax and because of campaigning activity in connection with the measures.

\section{The First Cigarette Tax}

The first cigarette tax was a bill passed by the 1965 legislature and referred to the people. The Hay 24, 1966 primary Voters Pamphlet described the cigarette tax as a measure that would "levy a tax of 4 cents on each package of 20 cigarettes sold in the State of Oregon." The measure was expected to bring in a total revenue of $\$ 10,430,000$ plus annually, of which $\$ 430,000$ would be retained by cigarette distributors as partial, although significant, reimbursement for their expense in handling. 
More important:

The funds collected would provide direct property tax relief to all property taxpayers and would be an additional source of revenue for cities and counties in the state. . . One half of the net amount collected annual$1 y$, or approximately $\$ 4,925,000$ would go directly for property tax relief. . . 36

Only one argument appeared in favor of the tax in the informational booklet compiled by the secretary of state; appealing to the voters in the name of property tax relief, citing a concern for the disproportionate share property taxes contribute to total revenue receipts, and arguing its stability in state financing. No arguments appeared in opposition. No money was spent on advertisements. No campaign was launched. And yet, for the first time in nearly forty years, the people of Oregon had approved a new tax, by 310,743 to . 181,957 .

$$
38
$$

\section{Tax Limitation Referendum}

In 1968 the one and a half percent tax limitation proposal was placed on the Oregon ballot. A group of citizens calling themselves The Oregon Homeowners Association, successfully collected 54,000 valid signatures in a petition drive which began during the summer of 1967 . The resulting Ballot Measure Number 7 appeared under the title: "Constitutional Amendment Changing Property Tax Limitation." If the measure had been approved, the six percent 1 imitation on property taxes would have been repealed and taxes would have been 1 imited to one and one half percent of the market value of residential property. The cost to local government was estimated to have reached $\$ 150$ million in lost tax revenue the first year alone. Since the source of 47.4 percent 40 
of all tax moneys in the state in 1966 was derived from property

taxes, the initiative had serious implications.

An organization was quickly formed to fight passage of the bill and proved to be one of the most tightly coordinated nonpartisan campaigns conducted in recent years. A paper written by the campaign director, Roy N. Vernstrom, outlines the sequence and scope of activity that surrounded the anti-one and one half percent tax limitation cam41 paign .

The original citizens meeting involved 25 persons representing interests from business, labor, government, religion and education. After the initial meeting, the group met biweekly throughout the campaign in an advisory capacity. The Strategy Committee, as it was called, was charged with the responsibility of reviewing progress on decisions made earlier in the campaign and acting upon new information obtained from feedback provisions: tours of the state and public opinion survey results.

The campaign director wrote that a public opinion survey firm and an advertising agency together with the Strategy Committee, Finance Committee, four state co-chairmen, a Speakers Bureau and 36 county chairmen made up the total task force. The campaign director made personal contacts to potential channel sources (editors and television commentators particularly), organized the "task force" phase, and generally coordinated the campaign in all of its details. As a result, the campaign was marked by clearly delineated areas of responsibility and frequent intragroup consultation with the teams involved. 42

On November 5, 1968, the voters rejected the Tax Limitation, even 
though it meant a state budget that would continue to rely heavily on property taxes. The vote was 503,444 to 276,451 , a ratio of nearly two 43 to one.

During the course of the campaign promoters had promised the people that if this measure were defeated, the next legislature would take some definite steps toward real tax reform. But leadership opinion regarding the form such change should take was divided. Republicans supported a sales tax, while Democrats were, in general, opposed. Following the defeat of the Limitation threat, Vernstrom wrote to over $\mathbf{5 0 0}$ representatives from interest groups around the state requesting their opinions on the possibilities available for tax reform. A similiar partisan trend emerged. A high proportion of business leaders as well as Republican legislators felt that a sales tax was the most viable source for needed revenue, providing it included a provision for property tax relief. The next session of the legislature put together just such a package.

\section{The 1969 Sales Tax Measure}

The 1969 Property Tax Relief and Sales Tax Measure was referred by the legislature and placed on the ballot in a special election called for June 3, 1969. The measure was a complicated one, involving both constitutional and statutory changes. The official ballot title summarizes the provisions: (1) the enactment of a three percent sales tax exempting food and prescription medicine; (2) constitutionally dedicating proceeds to reducing property taxes; (3) changing constitutional school property tax limitations; (4) establishing new property tax bases for schools which could not be exceeded without the people's vote. The 
measure also provided for (5) a restriction on the number of school tax elections and provided for uniform election dates; (6) increases to corporation taxes; (7) rebates to low income families from income taxes; (8) prohibited increased property taxes on homesteads of $\$ 20,000$ or less after the owner reached age 65 .

The 1969 legislature was well aware that voters were dissatisfied with increasing property taxes. The 60,000 signatures obtained by the Tax Limitation sponsors revealed voter discontent with Oregon's heavy reliance on the local property tax and the legislature was determined to put together a plan that would meet with a minimum of opposition. They knew that whatever tax reform was referred, no biennial projections could be made until the voter had passed judgment. It was for this reason that the 1969 legislature set an early date for a special election on the sales tax. It was also the threat of voter rejection that prompted the many provisions that were included. Jarold A. Kieffer put it this way: "We think of government and the role it must play. The real problem is that the people have terrorized the leaders."

The Republican controlled Oregon House had originally passed a variation of the measure providing that all revenue would be earmarked for support to public schools. The Senate version incorporated an amendmant so that revenue would go to the property tax relief account established with the enactment of the 1966 cigarette tax.

The Hcuse concurred with the Senate amendments. But prior to the conference committee approval, debate in both houses was characterized by partisan conflict. Democrats were strongly, opposed because the tax did not provide sufficient relief to the homeowner: all property owners, including corporations, receiving a proportionate share. The most serious 
disagreement, and the one that ultimately led to the sales tax defeat, was the tax shift effect: the homeowner would pay the tax, but would 46

receive little of the benefits. As a result of this felt inequity, the battle 1 ines were drawn before the legislature adjourned. The tax was referred, and the campaign began.

Those supporting the sales tax quickly organized political groups calling themselves, "Committee to Clear the Air," Committee for Sensible School Budgets," "Do Farmers Have a Future Committee," and "Oregonians for Property Tax Rel ief Committee," all naming Mrs. E.C. Schmidtt as secretary. Together, the pro-tax groups spent over $\$ 100,000$ in support of the measure whereas opponents expended less than one fifth that amount.

In spite of the relatively small expenditure level by opponents, 48

the base of support was much wider. State union organizations and many small locals joined with citizens and Democratic legislators who had been opposed to the measure when it was under debate in the Oregon legislature.

Barly partisan conflict over the tax shift effects continued throughout the campaign. Leadership in the state was seriously divided, major interest groups played conflicting roles, and in spite of intense efforts at obtaining the cooperation of neutral groups, repeated resistance was met. The voter remained unconvinced. As Kieffer said, the legislators were afraid the people would not "buy it," and they did not. Bvery county in the state opposed the measure on election day, by a total vote of 65,077 in favor and 504,074 opposed. 49 The Fifty-Sixth Legislative Assembly would face their biennial budget task once again 
without the benefits of tax reform.

\section{CONTEMPORARY FISCAL SITUATION}

\section{Legislative Dilemma}

The biennial balancing of the state budget reflects the general state economic climate. When the 1971 Legislative Assembly met, the state was once again facing financial crisis. Continued pressure on high property taxes combined with minimal increases in projected revenues were complicated by the Federal Governments decision to increase the personal deduction on individual income tax which automatically reduced Oregon revenue. In an effort to simplify tax forms, the state had patterned their program after the Internal Revenue Code in 1969.

The chief source of revenue in the General Fund is the income tax, extremely susceptible to outside economic conditions such as changes in the Federal Income Tax law on personal deductions. Not only was this change a contributing factor to the prospect of a budgetary deficit, other characteristics of the General Fund structure created fiscal weakness. The General Fund is the least flexible of state financial sources, obtaining its revenue and prerogatives for change in accordance with 51 legislative action and constitutional limitations. Both reflect its capacity to meet demands.

Required to balance the budget by constitutional law, the legislature's role was, ironically, like that of a woodsman with a broken axe. In the foreground stood the competing branches and departments of government urging upward adjustment in budget, appropriations, and in the distance stood the constituency, only recently reminding the legis- 
lature of their extreme reluctance to hand over the revenue needed for repair. Any tax measure that might come out of the 1971 session would face the possibility of another referendum.

The 1971 legislature responded to a projected deficit in the General Fund by adopting a bill allowing an increase in taxes on cigarettes, and by freezing the level of the personal income tax exemption at its current level. Even then the fiscal situation was relatively unstable as a dock strike that had started in January failed to be settled. By the time the regular session adjourned, the waterfront strike had shut down port activities for over 100 days, reducing the work force and halting all exports of Oregon commodities.

Without the revenue expected from the cigarette tax increase, the Fund faced a deficit which might have reached or even exceeded $\$ 35$ million in the biennium. The cigarette tax was judged to be the most acceptable to the people and met with the least opposition from opposing factions in the state legislature from tax measures proposed. Even so, historically the tax was not popular with the voters.

In 1945 the legislature had approved a cigarette tax and referred it to the voters only to have it turned down. It was proposed three more times--1947, 1952, and 1956--only to be rejected by increasingly greater margins. After waiting 10 years, the legislature had tried again in 1966 and finally won the voters permission to impose a four cents a package tax. 54

The increase of five cents a package to the old tax was supposed to take effect on September 9, 1971, and was expected to bring in $\$ 24.5$ million during the biennium. A portion of the additional revenue was 
needed to finance a new low-income property tax relief package that would go into effect with or without the increase in the cigarette tax. The original cigarette tax approved by the voters in 1966 provided that a portion of revenue realized through the tax would go into a property tax relief account (half of the revenue went to cities and counties, and half to the property tax relief account). From this account, all property--business, industrial and homes--received an amount of relief proportionate to the assessed value of the property. The 1971 legislature voted to change the distribution formula. The new refund provision established an open appropriation going to all property owners whose property tax exceeded four percent of their income. All of the cigarette tax funds, including the additional five cents in the new bill, was to go directly into the General Fund. The result of this change was the abolishment of the old property tax relief account. After the 1971 regular legislative session adjourned it was required that 90 days pass before the revenue changes could take effect. It is the activity that occurred following adjournment that is the major focus of this study. Chapter III and IV include a description of the referral drive placing the cigarette tax on the ballot and the special legislative session called by the governor to deal with revenue loss created by the delay caused by the tax referral. It is also a description of how the state succeeded within only forty days at convincing the public that a tax increase was in their best interest, when in fact certain groups stood to gain more than others. It is the story of the salesmanship of interest group leaders, elective and appointive state officials, paid campaign managers, and the people themselves. In sum, 
it is a case study of the communication processes in an issue based campaign on a referendum measure. 


\section{Notes}

Ioregon Bluebook 1961-62, p. 261.

${ }^{2}$ Robert E. Burton, Democrats of Oregon: The Pattern of Minority Politics, 1900-1956 (Eugene, Oregon: University of Oregon Books, 1970), p. 4 .

3U.S. Bureau of Census, Characteristics of the Population, Vol. II, Part 37, 1950: Oregon (Washington, D.C.: U.S. Government Printing Office, 1952).

${ }^{4}$ Burton, p. 4.

${ }^{5}$ U.S. Bureau of Census, 1970 United States Census: Oregon (Washington, D.C.: U.S. Government Printing Office, 1972).

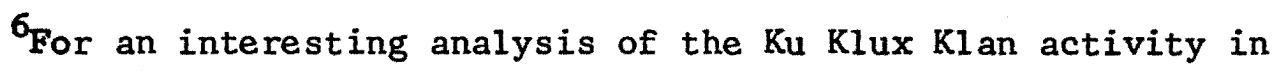
Oregon, see Burton, pp. 46-49.

${ }^{7}$ Lila Acheson Wallace School of Community Services and Public Affairs, Oregon's Dilemmas: Second Annual Conference (Eugene, Oregon: University of Oregon, May 16-18, 1968), p. 24.

I Ibid.

${ }^{9}$ For a discussion of Oregon's economic growth, see James $\mathrm{N}$. Tattersal1, "Economic Growth, Population, and Policies," Ibid.

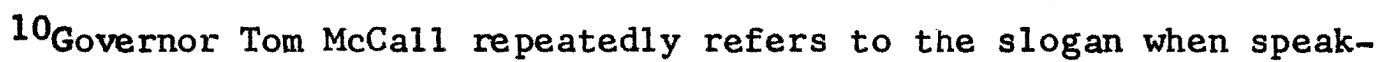
ing in other parts of the nation; Senator Robert Packwood was publically reprimanded by the Lincoln County Chamber of Commerce in 1971 for a similiar statement.

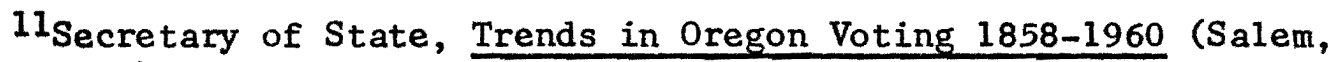
Oregon, 1962), cited in Burton, pp. 150-151.

12 Oregon Blue Book 1971-72, p. 237.

${ }^{13}$ Jonas, p. 310

14 Burton, p. 10 .

${ }^{15}$ For an excellent discussion of direct legislation effests during the first ten years, see Allen H. Eaton, The Oregon System: The Story of Direct Legislation in Oregon (Chicago: A.C. McClurg and Co., 1912.) 
16 Burton, p. 11; Senator Mark Hatfield, in his 1958 bid for governor virtually ignored the party organization. His campaign advertisements contained no mention of the Republican party, and he did not encourage the entry of supporting national party figures into the state. Governor Tom McCall followed thij pattern in his successful gubernatorial race in 1966. Robert Straub, his opponent, made much of party affiliation. McCall carried 33 of 36 counties.

17 Jonas, p. 310

${ }^{18}$ The 1 iberal Republicans answer to the Demo-Forum.

${ }^{19} \mathrm{Al}$ so elected were: two Republican Congressional Representatives, two Democratic Representatives; nine Democratic State Senators, seven Republican; 26 Representatives from the Democratic party and 34 from the Republican party. Ore'gon Blue Book 1971-72, PP. 253-255.

20 Jonas, p. 319 .

${ }^{21}$ Representative Frank Roberts, Democrat Multnomah County, conversation in July, 1972.

22 Jonas, p. 319.

23 Daniel J. Elazer, American Federal ism: A View from the States (New York, 1966), p. 90, cited by Burton, p. 14. p. 16 .

${ }^{24}$ Oregon Democrat, Vo1. 23 (February, 1955), p. 9, cited by Burton,

${ }^{25}$ Jonas, p. 320 .

${ }^{26}$ Signatures are determined by the number voting for governor at the last election: 4 percent for referendum; 6 percent for initiative; 8 percent for constitutional revision by initiative. "Constitution of Oregon," Article IV, section 1, in Oregon Bluebook 1971-72, p. 266.

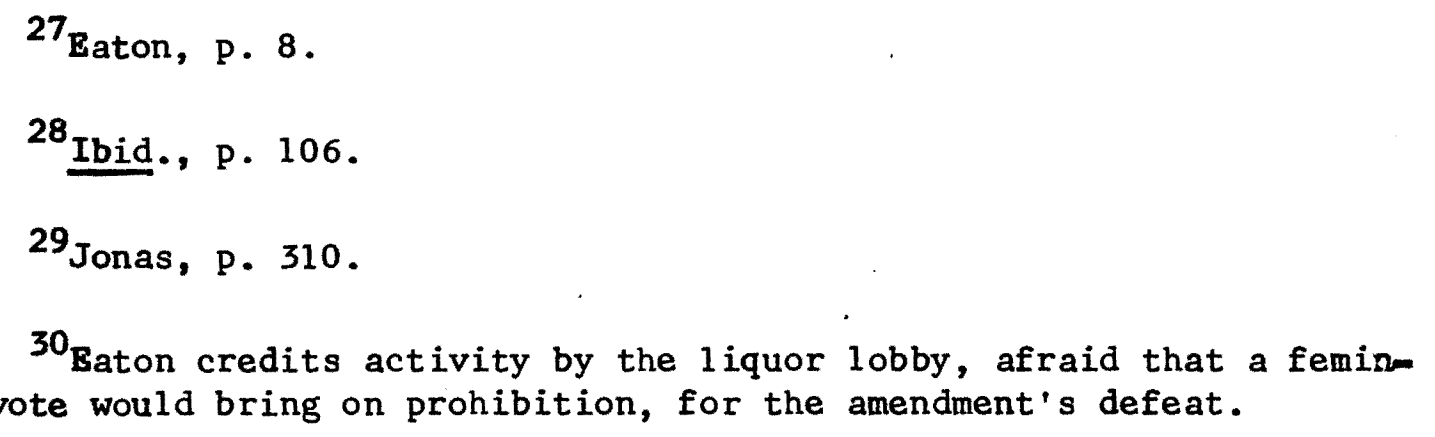


${ }^{31}$ See Eaton for a detailed description of the 33 measures rejected and 31 passed during the first eight years of the power of direct legislation, Pp. 16-81.

${ }^{32}$ Oregon Constitution, Article IV, Section 1.

33Eaton, pp. v-vi.

${ }^{34}$ Newsletter, Association of Oregon Industries (Salem, Oregon, December 28, 1971).

${ }^{35}$ State of Oregon, Voters' Pamphlet: Primary Nominating Election, May 24, 1966 (Compiled and Distributed by Tom McCall, Secretary of State, 1966), p. 4.

\section{${ }^{36}$ Ibid.}

${ }^{37}$ Summary Report of Campaign Contributions and Expenditures: 1966 Primary Election (Compiled and Published by Tom McCall, Secretary of State, Elections Division, 1966), p. 73.

${ }^{38}$ Oregon Blue Book $1971-72$, p. 259.

${ }^{39}$ Taken from notice sent to County Elections Officers by $\mathrm{Cl}$ ay Myers, Secretary of State, State of Oregon, September 8, 1968.

${ }^{40}$ Robert T. Campbel 1, "Oregon's Fiscal Dilemmas and Alternatives," in Lila Acheson Report, p. 31.

${ }^{41}$ Roy N. Vernstrom, "The Politics of Taxation," unpublished M.S. paper, Political Science Department, Portl and State University, December, 1968. (The paper will be available in September, 1972, at the University of Oregon library, Eugene, Oregon.)

${ }^{42}$ Ibid.

${ }^{43}$ Oregon Blue Book $1971-72$, p. 260.

${ }^{44}$ State of Oregon, Voters* Pamphlet: Special Election, June 3, 1969 Compiled and Published by Clay Myers, Secretary of State, Salem, Oregon, 1969).

45Jarold A. Kieffer, "Summary," Lila Acheson Report, p. 119.

${ }^{46}$ Roberts interview. 
${ }^{47}$ Summary Report of Campaign Contributions and Expenditures: 1969 Special Election (Compiled and published by Secretary of State, Elections Division, 1969).

${ }^{48}$ Ibid.

${ }^{49}$ Oregon Blue Book $1971-72$, p. 260.

${ }^{50}$ George Anala, editor, Your Taxes: Oregon Tax Research, Vol. 37 (Portland, Oregon, January, 1972), p. 2.

51 "Economic Report of the President," February, 1970, p. 181, cited in "A State-Wide Income Tax for Oregon Local Governments and it's Distribution to Cities, Counties and School Districts," Joint Finance Grmmittee of the Oregon School Boards Association, Association of Oregon Cities, League of Oregon Cities (1970), P. 1; Expenditures authorized by the legislature can come from two sources: the General Fund and "other funds." Close to 30 percent of total state expenditures originate from appropriations out of the General Fund and the remaining 70 percent is basically controlled by expenditure limitattions imposed on other funds, most of which provide or contribute to a special service or function of government Property taxes do not go to the General Fund; personal income taxes provide 47 percent of General Fund revenue. Oregon Tax Research, p. 2.

${ }^{52}$ Ibid.

${ }^{53}$ In an interview on June 30, 1972, George Anala, editor of the tax research bulletin, was asked about the possibility that Governor Tom McCall had overstated the significance of this deficit Anala's response indicated that $\mathrm{MCCal} 1 \mathrm{had}$ not, and that projections made by the state economist on the revenue to be realized by the cigarette tax was accurate. "If there is a surplus," said Anala, "it would be in the second year of the biennium."

54 Oregon Blue Book 1971-72, p. 259.

${ }^{55}$ Interview, Anala.

56" War of Words over Cigarette Tax Vote Heats Up," Oregon Journal, January 5, 1972. 
CHAPTER III

\section{CHRONOLOGY OF EVENTS}

June 10, 1971 Regular legislative assembly adjourns.

August 27 Attorney General indictes anti-tax promoters on corrupt practices violations in petition circulation procedures.

August 31

Accused violators arraigned.

September 10 Secretary of State receives petitions referring the Cigarette Tax to a popular vote.

November 16 Governor convenes special legislative session.

November 22-30 Tobacco distributors tried and convicted of corrupt practices violations.

November 23 Special session adjournes, H.B. 3064 approved.

November 29 Interested citizens hold first campaign planning session.

December 1 Agencies from public sector meet in Salem for planning session.

December 2 Coalition meets in governor's conference room.

December 7 Announced formation of committee in favor of the tax: "Citizens Against Raising Property Taxes."

December 17 Tobacco distributors appeal corrupt practices conviction.

December $27 \quad$ Kennedy polls show pro-tax forces leading.

December 28 News conference held announcing "Legislators Opposed to Cigarette Tax" formation.

January 3, 1972 State officials protest misleading anti-tax advertising.

January 4 First of series of OSEA-OEA public meetings in support of the cigarette tax. 


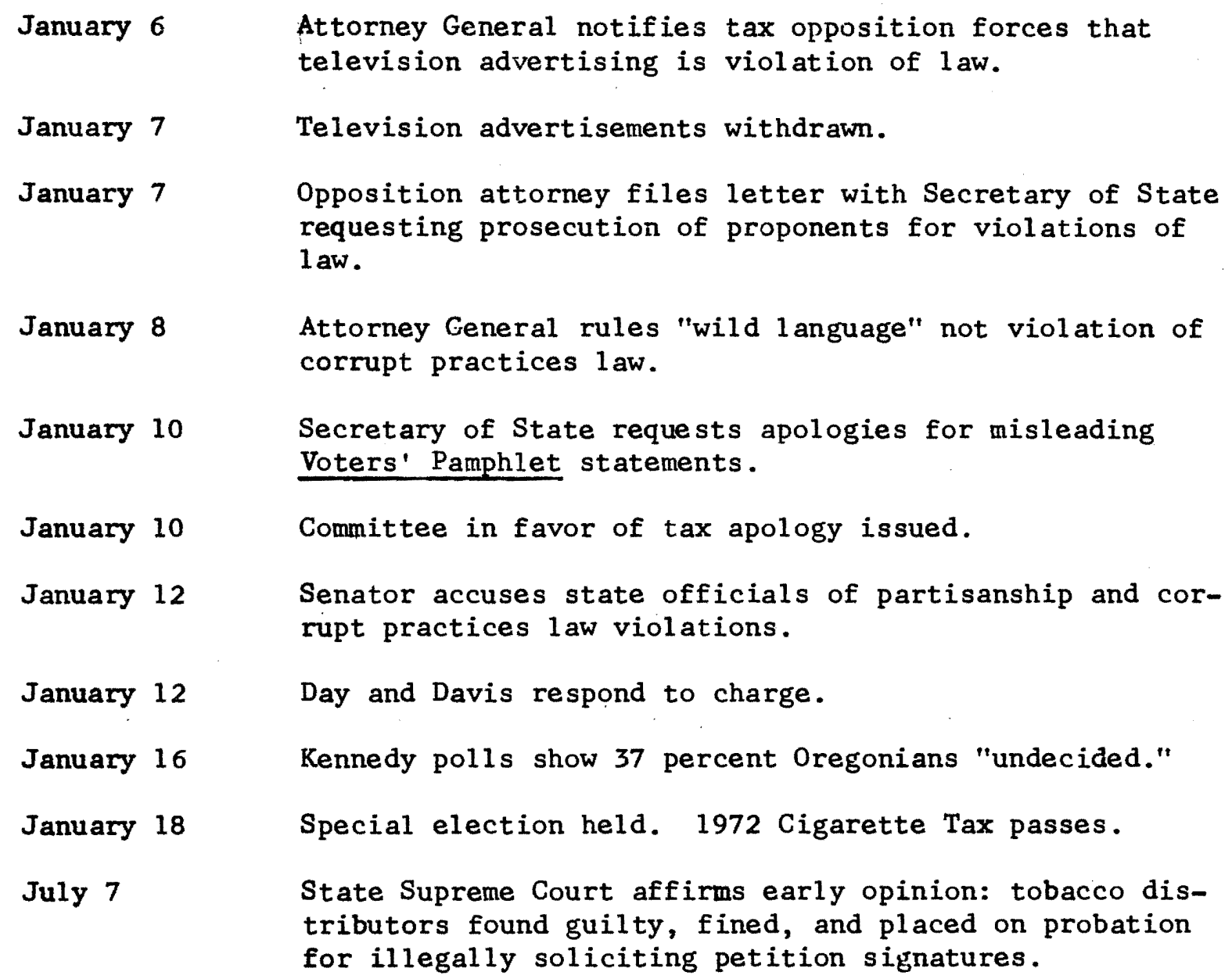




\section{CASE STUDY OF CIGARETTE TAX CAMPAIGN}

"War is political campaigning spiced with bullets," writes the author of Politics Battle Plan. "Both involve a collision of organizations seeking absolute victory; both are played in defined theatres; both are fought by tactics of applied weaponry; and both are won by the grand strategy best combining factors of time plus force and the ability to win confrontations--surmounting hostile pressures while impos1

ing decision upon the enemy."

While the "war" analogy will not carry us very far, it is apt. In military campaigns as in initiative campaigns in Oregon, it is difficult to know with certainty which tactical maneuver succeeded and with whom. But upon close observation certain recurring patterns tend to assert themselves and certain personalities and social systems become distinct. In the 1971-72 Cigarette Tax campaign both a coalition and collision of interest group forces seemed to have dominated the battlefield.

\section{FORMAL PRESSURE GROUPS}

Special interest organizations have traditionally played key roles in Oregon politics. "Idea" groups, like the Oregon Council of Churches, the League of Oregon Voters and the Federation of Women's Clubs, consistently take positions on measures and occasionally on 2

candidates. "Economic" interest groups such as the vending machine, race track, and public utility interests are small in terms of the number of persons they represent, but have proportionately greater funds available than groups depending on membership dues for lobbying activity. 
Accordingly, they feel no reluctance in using their financial advantage in attempting to influence both the legislature and the public in their behalf.

Lumbering, labor, education and transportation interests, according to political scientists Swarthout and Gervais, make up the "big 3

four" pressure groups in the state. The Grange, active in past years, i:has now been replaced in influence by the larger Oregon Farm Bureau Federation, made up exclusively of farm interests.

of the two pressure group functions--traditional lobbying (working for favorable legislation and supporting candidates friendly to their interests) and the less frequent function of attempting to influence the electorate at the polls on key ballot measures, the latter is of particular importance in Oregon, and of special interest to this study .

Popular legislation, after all, represents a direct battle among interests, without the intervening influence of party or legislative structure. Interest groups often are the driving force behind an initiative or referendum petition at the outset. ${ }^{5}$

Such was the case in the Cigarette Tax Referendum of 1971 . Tobacco wholesalers funded the opposition after successfully placing the measure on the ballot. In the following months the Oregon State Employees Association, Oregon Education Association, Associated Oregon Industries, and a myriad of smal ler cause and interest groups met the opposition head on.

II. THE REFERENDUM DRIVE

The original offensive was launched when the tobacco interests combined with a professional lobby to finance and coordinate a drive to 
refer for popular vote the increase to the cigarette tax passed by the 1971 legislature. During the summer months and especially the third and fourth weeks of August, workers gathered over 26,656 valid signa6 tures. Unlike the large formal economic interest groups, the tobacco wholesalers lobby had no membership to draw from in circulating petitions. Accordingly, Ron Campbell, a Portland teacher, coordinated the drive and hired high school and college students to circulate the petitions in the Portland metropolitan area.

Both Campbell and Ken Rienke, the tobacco lobbyist sponsoring the initiative drive and coordinator-planner of the anti-cigarette tax campaign that was to follow, were aware that paid solicitation of signatures was illegal. On August 19, 1971, they told the Marion County Circuit Court that the petition drive would test the constitutionality of the 1aw. The court ruled that the 1 aw could not be tested until it had been violated. Together with Ed Collins and Sylvan Campf, local tobacco distributors, Rienke decided to go ahead with the plan to hire circulators.

The petitions had been drawn and the language approved by the secretary of state in late July. By August 1, the petitions were in circulation, first in a fair booth at the Multnomah County fairgrounds and later on the streets of Portland.

The major signature collecting effort began and terminated within an eight day period. By the end of this time, over 300 students had been placed $\mathrm{cn}$ the payroll. When the attomey general obtained a court injunction ordering a halt to the arive, most of the necessary signatures had already been obtained.

When several high school students hired by Campbell were arrested, 
the drive caught the attention of the Oregon press. News of the student arrests, and charges leveled against two of the petition sponsors-Sylvan Campf and Edward Collins--for violations of the Corrupt Practices Act (Section 260.) forbidding "petition-hawking," made front page news. The students were fined and released, but charges against Collins and Campf, supported by the courts after an appeal attempt, resulted in not only a fine, but a three year probation as well.

Oregonians are generally opposed to ethical violations in political campaigns of any nature, with or without a law to direct them. Even though the Corrupt Practices violation attracted public attention to the petition drive and may have resulted in more signatures, according to Campbell, public opinion polls demonstrated that any support for the anti-tax forces had dissolved by December.

\section{MCCALL CONVENES SPECIAL SESSION}

On November 16, 36 days after the cigarette tax had been referred, Governor Tom McCall called the legislature into special session. The purpose of the special session was to reduce state expenditures by $\$ 32.6$ million in order to accomodate shortages created as a result of reduced individual and business tax collections, reduced interest earnings, reduced 1 iquor sales and potentially reduced cigarette tax revenues. The legislature's first act was to advance the election date on the cigarette tax increase from the Novemuer General Election, to January 18,1972 , in an effort to minimize losses in revenue to General Fund recipients (Figure 1).

With the explicit task of revising the budget, the legislature passed H.B. 3064, requiring a reduction of two percent in all General 


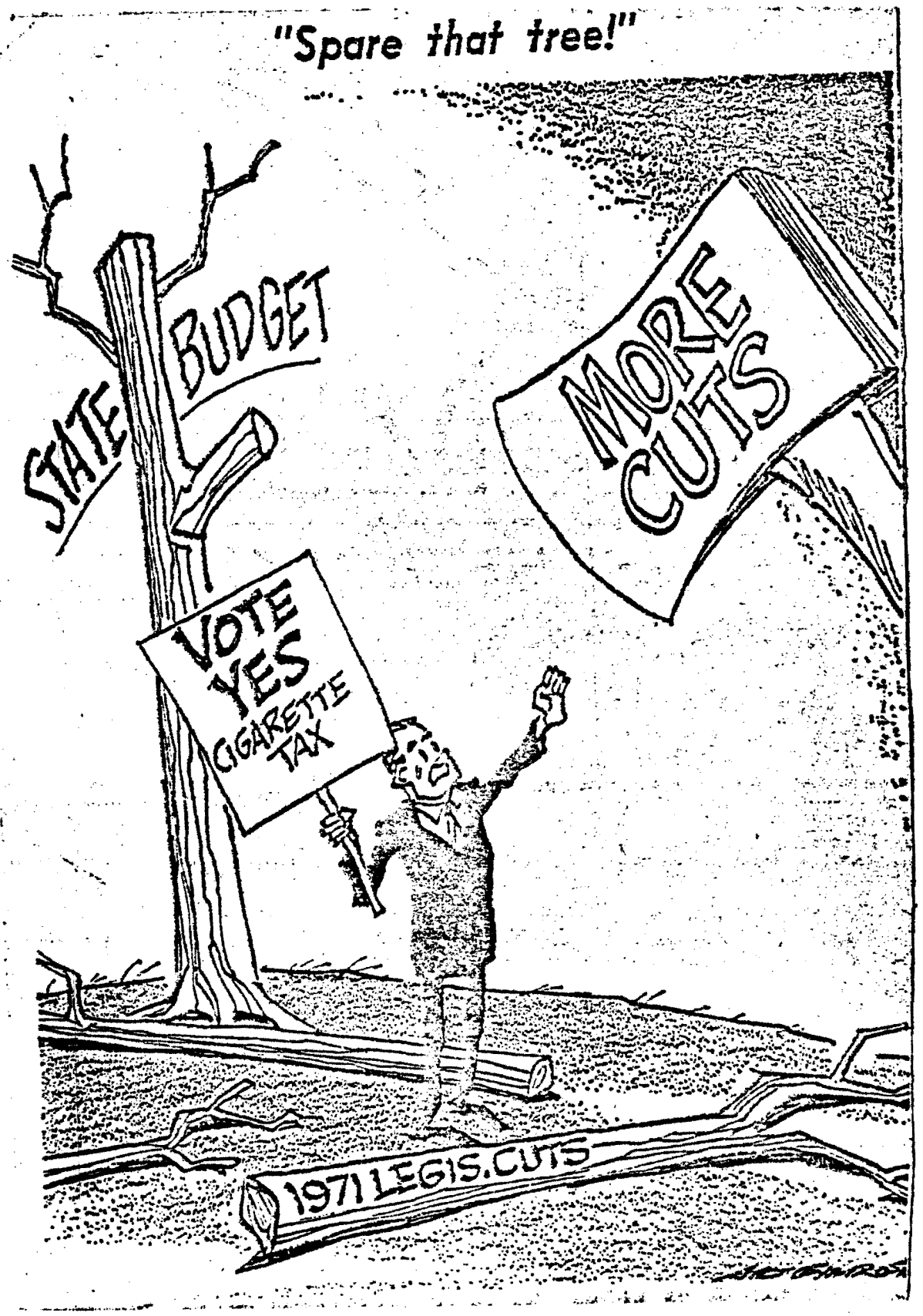

Figure i. Editorial cartoon illustrating Oregon fiscal situation in 1971; Oregonian, December 3, 1971. 
Fund appropriations for the 1971-73 biennium (with the exception of the Emergency Fund) if the cigarette tax increase were to fail. Property tax relief benefits were to be reduced an equivalent percentage but only in the second year of the biennium.

Translated into dollars, H.B. 3064 provided that defeat of the tax increase would have these effects: from an estimated $\$ 270$ million in aid to local governments, $\$ 5.4$ million would have been cut, forcing city and district agencies to look to an increase in property taxes to maintain the status-quo. Education, which accounts for approximately 55 percent of the General Fund budget, was to be left intact; but Basic School Support, increased at the 1971 session, would lose more than $\$ 4$ million and community colleges were scheduled to lose approximately 13

$\$ 735,000$. For a detailed account of the adjustments made during the special session, see Table 1 .

Small wonder that special interest groups quickly resolved to take action. The two percent cuts translated from dollars to human costs meant new programs eliminated or severely threatened, cutbacks in jobs, and recent gains in property tax relief reduced. For business interests there loomed the possibility of an alternative revenue source, an increased corporate tax, being approved by the legislature in another special session. With only one out of a thousand persons in the state corporation owners, the possibility of launching a successful initiative or referendum to counter such a development would be dim. In this re14

spect business interests were especially vulnerable.

\section{MOBILIZATION ACTIVITY}

As soon as the referendum drive was known, leaders of the groups 


\section{TABLE I}

EFFECT OF DEFEAT OF TAX MEASURES

ON MAJOR STATE PROGRAMS

\begin{tabular}{cccc} 
1971-73 & $\begin{array}{l}\text { Cig. Tax } \\
2 \% \text { Reduc. }\end{array}$ & $\begin{array}{c}\text { Income Tax } \\
2 \% \text { Reduc. }\end{array}$ & Total \\
Net Approp. * & (Effec.Feb.1) & (Effec.July 1) & Reductions \\
\hline
\end{tabular}

$$
\begin{array}{rrrr}
\$ 203,490,468 & \$ 4,069,809 & \$ 4,069,809 & \$ 8,139,618 \\
36,770,720 & 735,414 & 735,414 & 1,470,828
\end{array}
$$

Department of Higher

Education:

General Support $\quad 130,636,890$

Tchng Hospitals $\quad 14,746,034$

$$
\begin{array}{r}
2,612,738 \\
294,921
\end{array}
$$$$
2,612,738
$$$$
294,921
$$

$$
\begin{array}{r}
5,225,476 \\
589,842
\end{array}
$$

Department of Human

Resources:

Public Welfare

Mental Health

$66,555,110$

$1,331,102$

$1,331,102$

$1,211,681$

$1,211,681$

$60,584,060$

404,614

404,614

$2,662,204$

$2,423,362$

809,228

Property Tax Relief

$37,850,000$

757,000

757,000

$1,514,000$

(Estimate)

TOTALS

$$
\$ 570,864,004 \$ 11,417,279
$$

$\$ 11,417,279$

$\$ 22,834,558$

*Original appropriation by Regular Session plus Emergency Fund allocations, less Special Session reductions.

Source: Oregon State Employees Association, "Fact Sheet," December, 1971. 
potentially affected became concerned. They were well aware that some form of fiscal impact on their membership was imminent. The problem was identifiable but the dimensions were not clearly outlined until the special session convened.

Independent of action by other groups, the Oregon State Employees Association leadership decided that their members were anong those who would be seriously affected. On November 20, 1971, the OSEA Board of Directors, upon the recommendation of their executive secretary, Thomas Bnright, approved $\$ 5,000$ to 1 aunch a defensive campaign.

Jacob Tanzer, the newly appointed Director of the Department of Human Resources, is unclear about the exact date when he decided to move in behalf of his agency, but noted an early belief that something should be done and expressed these feelings to Bob Davis, the governor's 16 assistant, at a regular staff meeting in early November.

Other groups in the state were also independentiy evaluating the potential impact; Ruth Shephard, a private citizen working with the Council on Aging, and Alton King, administrative assistant to the student body president at the University of Oregon, both in Eugene; John Danielson, legislative director of the Oregon Education Association in Portland; Roy Lieuellan, chancellor of the Board of Higher Education, Eugene; Ike Congleton and Lou Norris of the Association of Oregon Industries, Salem; and Donald Jones, executive secretary of the League of Oregon Cities. Mrs. Shephard and Alton King met insormally in mid-November and agreed to cooperate in forming a coalition between youth, representing college students from state colleges, and senior citizens contacted through the State Council of Senior Citizens. In November, Mrs. Shephard 
presented a proposal to the State Council meeting in Salem, urging that they take action. At the same time, Jack Nelson, president of the council, accepted an offer made by King suggesting the advantages of a student merger. The coalition officially formed; as youth joined with senior citizens for the first time in an Oregon political campaign.

In the early stages, prior to and during the special session, activity among the formal organizations was largely confined to informal conversations within the leadership structure of each group. For example, William Lesh, of the AOI, reports that he was unofficially assigned the task of working directly with the state committee before the 18

committee had even been designated. John Danielson, representing public school teachers, said that once the referendum was as sured, his organization realized that some form of campaign activity would be necessary. During the special session legislators made it known that public education would be expected to contribute to the campaign effort as did the governor's assistant. Accordingly, on November 29, 1971, the OEA legislative director mailed a memo to every local OEA affilliate in the state alerting them to prepare to "develop strategies in support of the 19 cigarette tax measure."

Most of the groups that were to play a role in the next several months of active campaigning were concerned, but with the exception of the OSBA and the youth-aged coalition, none made visible campaign committments until the legislature had spelled out the exact form impending budget cuts would take

\section{Activity in Phase I}

The two percent cuts provided for in H.B. 3064, seemed to be the 
impetus that brought formal organizations and informal cause groups finally together in the first phase of formal activity.

Alton King, of the student-aged coalition, reports that the week following the special session's adjournment, representatives from universities and high schools in the state met with representatives from the Council of Senior Citizens in Salem. At this meeting, the first inter-group gathering of the campaign, Jack Nelson, Ron Schmidt (press assistant to the governor), Robert Davis (executive assistant to the governor), former state senator, Arthur Ireland, and King discussed the resources available and considered who might be recruited to coordinate a state-wide campaign effort. The meeting was informal and only tentative strategies were decided upon, but they did decide to meet the next week when more people could be involved.

On December 1, also in Salem, representatives from the public sector gathered, including: the executive secretaries from the Association of Oregon Cities, League of Oregon Cities, Oregon School Boards Association, Oregon State Employees Association, and Oregon School Employees Association. Also in attendance was the legislative director of the Oregon Education Association; Dale Parnel 1, superintendant of public instruction; and Roy Luellan, chancellor of the State System of Higher Education. These men met with the purpose of deciding on the direction their organizations or agencies should take. They agreed to emphasize the internal campaign, each group utilizing its own resources and channeling communication to their members. Only secondarily would there be a focus on the external, state-wide general campaign. Each representative also agreed that his organization would contribute money 
to the general campaign.

On December 2, a third organizational meeting was held. This time over 25 interested citizens gathered in the governor's conference room, and included among others, the original coalition members. New additions to the original group included Wally Liens, president of the Community College Student Association; Charles Dunn, administrative assistant to the Oregon State University student body president; Raymond Hollaway of the Martin Luther King Foundation in Portland; and at least 22

one representative from a Salem area high school.

Robert Davis, executive assistant to Oregon's governor, was also in attendance, and as the governor's closest assistant, would play an important role in future weeks. In an interview, Davis reported an early concern about the possibility of a successful referendum drive. Talking the issue over with Governor McCall, and obtaining his permission to perform an active function in the campaign, Davis began to make preliminary contacts while the special session was still meeting. It was a conversation with Mrs. Shephard that resulted in his presence as the governor's representative at the two coalition meetings.

According to Davis, it was at this second meeting that the cam- paign peramaters were set. With the limited time available to organize and implement strategy, it was decided that the large committee should not be involved with every strategy decision. Apparently there was consensus, and the decision making authority revolved to the governor's assistant and subsequently, the two other members of the soon to be developed "team": Brad Davis, private campaign consultant, and Ted

Hallock, owner of Ted Hallock Public Relations, Inc.. 


\section{STATE CAMPAIGN}

Decision making authority in the general state campaign was divided. Bob Davis brought in Ted Hallock, with the coalition committee approval, and together with Hallock, decided on the third member of the team--Brad Davis, a free-1 ance campaign consultant. In no respect can any one of them be said to comprise what is generally recognized as a formal campaign manager. Each had clearly defined responsibilities. The three consulted almost daily on a variety of campaign concerns, but they might better be termed "technical specialists."

As a communication specialist, Hallock had almost sole responsibility for implementing and planning media appeals. His public relations firm not only wrote and produced radio and television spots, but determined where they would be used, the audience to whom they were to be directed, and the timing of the appeals during the forty-day campaign. Working directly with Brad Davis, and consulting with the governor's assistant, the public relations firm settled on a "theme" which then dominated all mass communication appeals in both visual and auditory 25 mediums.

Brad Davis was selected because of his experience in past Oregon political campaigns. It was he who was to contact and coordinate the activity of various interest groups, provide speakers to civic clubs upon request, write specialized appeals for interest group members, and generally guide all features of the campaign not directed by either Hallock or Bob Davis. By letter and by telephone, the consultant learned the interest group organizations and disseminated the only printed materials put out by the state "committee." 
The governor's assistant worked with all groups and organizations although official coordination was the responsibility of Brad Davis. "The role of this office cut across the entire campaign," writes Bob 27

Davis. Aside from daily consultation with the other two members of what will be called the State Committee, Davis's chief responsibility was fund raising. Quietly and behind the scenes, Davis and John Fulton, also on the governor's staff, made informal contacts with government and organizational influentials, keeping them informed of the campaign progress and providing direction when requested. "I would surface only if Brad had a problem with a group. Late in the campaign I surfaced publicly, first in television appearances with Haas [Senator Harl Haas, D-Portland, and began to appear both against him and by myself. These were public affairs view-point kinds of programs. The only other time I appeared was to respond to Cook's Vern Cook, D-Gresham criticism that my position as a public employee was illegal."

William Gilbert, a Lake Oswego realtor, was designated treasurer of the committee that became the cover organization for the general state campaign, "Citizens Against Raising Property Taxes." But aside from keeping the records of contributions and expenditures, Gilbert had little to do with the actual campaign.

The three-man team of Hallock, Davis and Davis, formulated and implemented campaign strategy; and while they informally conferred with members of the original coalition, and a few others, it was in every 29

practical sense, a "three man team."

Ted Hallock and Brad Davis had decided that, in view of the complexity of the funding issues, "the thrust would be emotive rather than physically directed." 30 They would talk about issues vital to specific 
groups of Oregon voters The same men decided that instead of trying to talk to all of the voters with the same arguments they would create messages directed to six or seven categories within the population: people in higher education; on welfare; in Oregon's private collages and universities; community colleges; public employees; in business; and the general property owner.

Once that decision was made, a number of men, "paid loaned executives or paid to operate full time," were informed. After talking with them, and several state agency heads, Brad Davis and Hallock began working on the structure of the messages. Davis explained that the final decision making authority on structure and content of the various campaign messages evolved to three people. "In a longer campaign you can get away with making a series of mistakes and then adjust. With one like this you'd better put the ball into the hands of a few people who know the mechanics of political communication and rely on their 31

abilities." (Figure 2)

\section{Campaign Strategy}

The State Committee was concerned with three major activities: fund raising, mass media utilization, and special interest group coordination. Of the first two, media use was contingent on sufficient funds, therefore a great deal of early campaign energy was directed to this phase.

Fund Raising. The "Vote Yes" people had set their early campaign 32

fund goal at $\$ 60,000$, but later revised it downward. Bob Davis assigned several organizations modest quotas, principally those in the business sector. A large number of organizations contributed funds prior to being 
GENERAL CAMPAIGN DECISION MAKING STRUCTURE

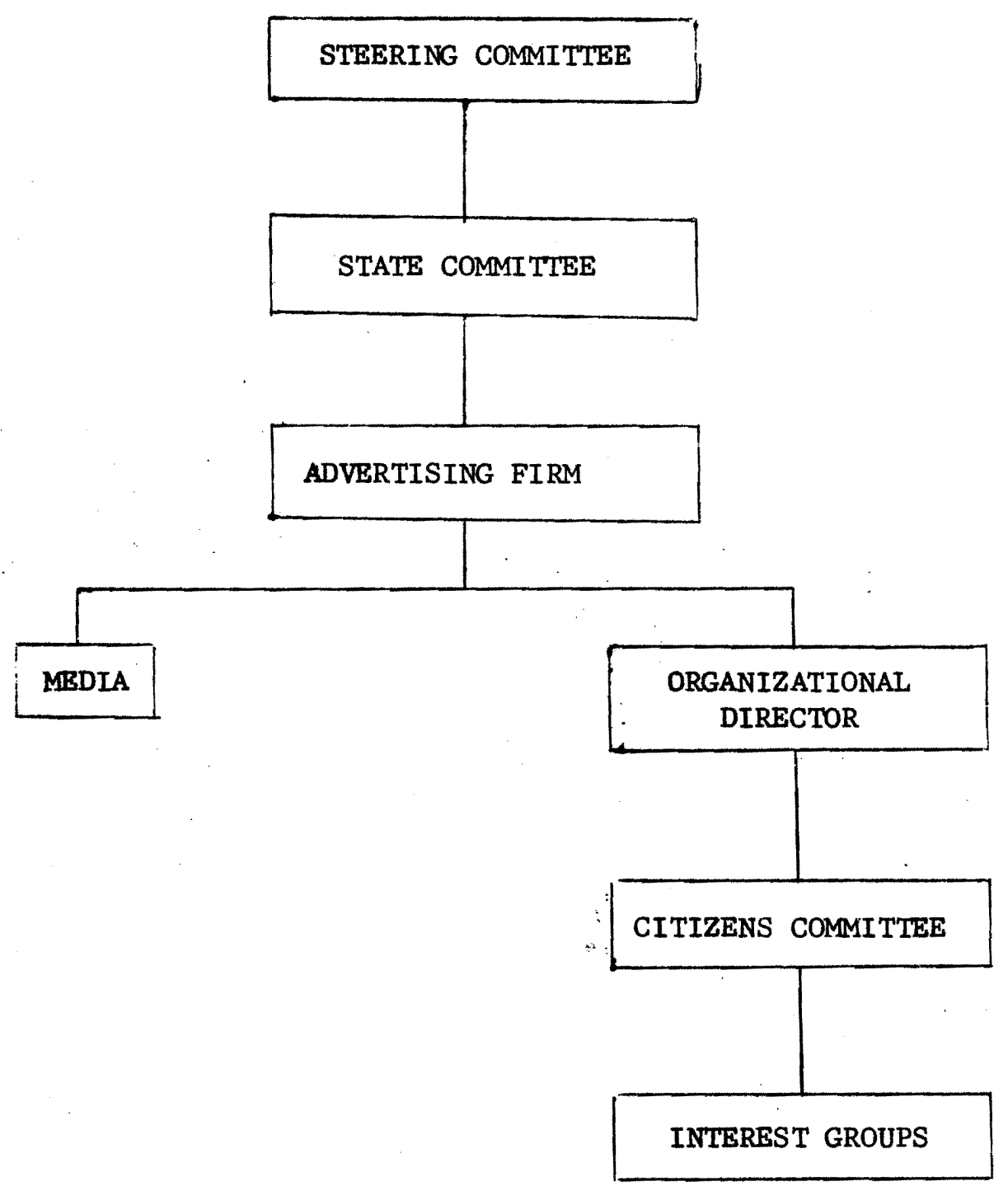

Figure 2. Decision making structure of state campaign. Source: Ted Hallock, interview in Portland, July, 1972. 
asked and others, for the most part, fulfilled their assigned quotas. Money had been authorized by the board of directors of the Oregon State Employees Association prior to the formation of any state campaign committee and it was unlikely that they would have contributed more. Moreover, the mere fact of a contribution from this organization consti33

tuted a "first." The Oregon Education Association's political action arm, a parallel organization with revenue dedicated to advancing educational interests through the political process, donated $\$ 1,000$ directly to the State Committee, Iike the OSEA, prior to any direct contact from 34 the governor's assistant.

Other organizations also knew that requests for money would be forthcoming. One business source reports that in mid-November, Bob Davis had announced the governor's intention to call another special session if the tax proposal failed at a meeting of the Emergency Board. A number of business interests were represented at that meeting. Faced with the possibility of an alternative source of revenue being drafted at a second special session, perhaps a corporate tax, the business community was prepared when the request for money came. 35 The secretary of state's records show 17 major contributions coming from lumber producers, insurance interests, produce wholesalers, and retailers. Other industries contributed to the State Committee indirectly, through the ad hoc committee associated with higher education.

Many of these same organizations were asked not only for financial assistance, but for "loaned executives" to assist in the coordination of volunteers in canvassing other potential contributors, or as one such executive put it; "influencing the influentials." 
A great many methods of fund raising were used. Mass solicitations are frequently emphasized by consultant personnel in national political campaigns, and were used to some extent in Oregon, but indirect means were used more often: with interest groups and the small locally based cause groups. Direct personal soliciation was used by Davis to make the initial contacts to special interest groups: letters and phone calls principally, and direct face-to-face conversation. Mass solicitation was used in appealing to the individual citizen without 37 calling on him in person. At Portland State University, for example, memos appeared in the mail box of every university staff member, asking that a contribution of any size be sent to the local tax committee chairman of Friends of Higher Education.

In spite of the impressive figures and the number of organizations contributing, the secretary of state's ledger sheet does not tell the entire story. Money came in from isolated and unusual sources in this campaign. George Diel reports that the ad hoc committee for higher education interests received contributions from a total of 1,524 separate sources; 1,511 people donating less than $\$ 25$. Many contributors gave less than $\$ 5$.

In Corvallis, where the strongest on-campus activity occurred, the fund raising drive was kicked off at a large gathering of civic leaders, businessmen, and members of the academic community, called together by the university president, George McVictor. At Oregon State University the president pointedly requested contributions; Corvallis businessmen 39

were asked for $\$ 50$ or more. Later, the Gazette-Times editor appealed for funds through an editorial reporting the status of the state campaign. Numerous university affiliated organizations requested money 
from members. At Portl and State University, University of Oregon, and on most of the smaller college campuses in the state system, various fund raising activity was carried out, ranging from "low key" appeals to faculty and staff members, to "passing the hat" in dormitories and 40 fraternities by student volunteers.

Ursel Narver and Frank Brawner, chairman and treasurer respectively of Friends of Higher Education, mailed an Emergency Memo to al 1 members of governing boards, community colleges, independent college governing boards and other people who were judged to have a deep interest in 41

higher education. The memo urged that recipients vote, influence their friends and associates to vote, and called for contributions, "whether $\$ 10$, or $\$ 1,000$, or less, or more."

Fund raising became a major communication function of the state campaign and it is important to note the activity of many individuals as well as the larger outright contributions from interest groups. The final $\$ 13,152$ sum collected by the higher education community represented the commitment of a great many "little" people and their concern that the cigarette tax pass.

Communications related to the fund raising phase originated in the office of the governor and flowed throughout the state. In the instance of higher education, the network began when Bob Davis issued messages from his office by way of direct personal telephone contacts to the chancellor of the State Board of Higher Education who in turn issued a memo to George Diel in the Portland chancellor's office. Diel then set into motion the mechanisms that would further disseminate the plea for funds to increasingly more finite groups and individuals. One 
of these groups, the Oregon State University administration, further passed the message along to staff members, faculty, and in some cases, students, depending on the nature of the request.

In some instances the message channels crossed as they did in Corvallis, when Robert Ingalls, editor of the Corvallis Gazette-Times, obtained information about financial needs directly from the legislature where he serves as a house member, from Friends of Higher Education, and from the Oregon State University administration. 44 He in turn passed the information on to his readers. Unfortunately, after this point we have very little way of knowing to what extent the network widened.

In any case, despite the severe Iimitations of time, a war chest was collected, many communication channels were opened, and it remained the task of the State Committee to decide how the money might best be spent.

\section{Mass Media Utilization}

In the early days of the formal campaign the coordinators had no equipment and no advertising program. The final sum collected by the fund drive was something in excess of $\$ 29,000$, therefore maximizing effects of somewhat 1 imited resources was the major objective of the State Committee and all decisions were directed at this objective. It had been decided that the most effective way to reach a great many people was to utilize existing organizations and pitch appeals to the specialized economic interests in the state. This was Brad Davis's function.

The decision that led to this maneuver is of sufficient importance in a consideration of campaign strategy that the text of Brad Davis's 
comments deserves to be quoted extensively:

Previous methods of describing campaigns in this state has been to describe the impact in terms of dollars. We felt that people were surfeited with this. They were numbed by three hundred million dollar figures, so we decided early that rather than talk about simply the effect of the increase, the 17.6 million dollars that would be generated by the tax, we would talk in human terms about the impact.

So we transformed the measure from dollar impact to human impact. Even more, we knew that we couldn't talk to the entire body-politic, so we picked out five categories of people that could have lost severely should there have been a selective tax cut. The groups we looked at were: the stucents; public employees, broken down into highway crews, public employees like OSEA and OEA members, state policeman; labor; business; and a fifth group, "other," which represented major associations that didn't fall into the other classifications.

While the opposition was trying to lay charges at our feet which were irrelevant and mostly false--they were general arguments so they dilluted their campaign dollar. We maximized ours by saying that we could not talk to all of the people of Oregon at one time with one story. We will talk in human terms to all of the interest groups who will lose if the measure goes down. 45

Within these dimensions, the campaign progressed, from an early and in the overall picture, minor attention to public meetings, to later communication including radio, television and brief "fact sheets." Davis put out 15 different fliers, each with the same theme but each designed to appeal to a specific group of Oregon voters.

Two of the fliers were generalized: one, a five page informational photocopied brochure described the selective cut argument, and the other, a single page table describing cigarette tax rates nationally with Oregon's tax percentage set in bold type. The thrust of arguments in the several fact sheets was the creation of a hypothetical situation: "IF the governor called a special session, cuts MIGHT be directed at one particular program." Then followed the argument that the two percent 
across-the-board cuts would not be implemented until the following year, doubling the percentage. Compounded by an additional two percent cut if the federal and state income tax laws were not divorced, a cumulative eight percent COULD be slashed from existing programs. Further, the fliers said that it would be possible that a special session would be called by the governor to deal with the problem.

(Several fliers directed to special interest groups are included in Appendix E.)

Other fliers followed the same general line of reasoning, but the language was structured to appeal only to the group to which each was directed. The following structure was used in a message intended for the low income voter:

Without your "yes" vote, the following state assistance to the poor may be stopped: 1. PROPERTY TAX RELIEF for low income homeowners. 2. 5,362 PATIENT DAYS in the Multnomah County Hospital and University of Oregon Medical schoois. 3. \$180 ANNUAL for a family of four receiving public assistance. 4. NEEDED MENTAL HEALTH TREATMENT for one out of 47 eight persons with drug, alcohol and other emotional problems.

"A doubling of tuition, reduction of teaching faculty, and halting of general fund expenditures for OSU Cooperative Extension, Experimental Station, teaching hospital and clinics, etc.," was directed to higher education. Fliers going to community colleges warned of "a reduction of 84.3 percent of state support"; to the property owner, "loss of $\$ 97 "$; to public elementary and secondary schools, "loss of $\$ 34$ per child"-all IF the cuts were made selectively.

These pointedly exaggerated fact sheets were disseminated to the leadership of each of the interest groups with a footnote saying that further information would be provided upon request. In many cases the 
leadership of the organization receiving the advertising decided not to use them. Enright, of the OSEA, expressed dissatisfaction with the "scare approach" accentuated by "loaded language." 49 Using the same basic information, the OSEA designed and distributed its own version. Friends of Higher Education did the same, as did the staff of the OEA. of the many interviews conducted in preparation for this study, only two informants reported that the materials were appropriate for use in their organization. We can conclude from this that the flow of influence provided by this communication medium ended at the institutional level, reaching few people beyond the leadership in each organization. The target audience for the electronic media appeals was the "uninformed, uninterested, and independent voter" who, according to Nimmo, is the audience most influenced by television and, to a slightly 50

lesser extent, radio. Hallock's public relations firm was well aware of the nature of the audience and had clearly formulated theories about how to reach them. According to Hallock, the goal was to reach people who were not members of formal interest group organizations and who would be unlikely to be influenced by "objective, colorless advertising." 51

Media support was altogether planned for the Portland area; a decision made necessary by the shortage of campaign funds. Television was the top priority, but spot advertisements on radio stations accounted for 20 percent of the budget. Approximately 200,10,30, and 60 second time slots were purchased on the three Portland stations with the largest 52 audience.

In addition to the arguments used in the printed literature, the 
radio advertisements adopted several more: smoking is a luxury; if the tobacco lobby wins, Oregonians loose; and smoking is bad for the health. Bleven seperate messages were designed for the radio audience and of these, three used the property tax rel ief argument; one each referred to public health, the tobacco lobby, cuts in environmental quality control, cuts to schools and kids, and smoking as a luxury. The three 60 second slots used all of the arguments in staged spontaneous dialogue. The following is an example:

(A friendly male voice) Yeah, I'm going to vote for the cigarette tax. I mean...those guys in the tobacco industry, you know...they can defeat the cigarette tax 'an pick up their profits and run home. But me...I gotta live here.... I' $m$ the guy who, if the cigarette tax fails, doesn't get property tax relief. Either that, or they could take more money from the school budgets. Some guys say, you know, cut the budgets some more.... Cut-out the spending an' throw out the bums. And I say, OK, which bums? You mean...bums like the kids in mental health? You know...there's this little girl... Desiree. She couldn't feed herself, couldn't walk. They said she'd never walk but she's walking. You want to throw those bums out? I don't. Oh, I smoke, Man, do I smoke. But--am I gonna vote for a cigarette tax? Yeah. Yeah, you bet I am. (DRUM) Vote yes January 18th. Tax cigarettes, not property. (Disclaimer) ${ }^{53}$

Another ad explained the benefits of the Boy Scout program to the mentally retarded boys in Fairview who had "convicts for den fathers," so "they both learn, and it lets two institutionalized groups help each other...it doesn't cost much." The third 60 second slot also pleaded the benefits that the Human Resources Department provides to Oregonians. The remaining 80 percent of the media budget went into television advertising, far more expensive, and consequently fewer advertisements were purchased. Like radio, the video message argued the human impact of dollars cut, the dangers of smoking, potential increases to property taxes, and out-of-state tobacco "carpetbagging." Also like radiō, the 
longer advertisements strived for spontaneity and emotional impact.

The same advertisement that on radio talked about mentally retarded boys, used a pan shot focused on the boys working on their badges, followed by the expressive voice of a man saying, "This is just ONE of the programs that can die without the cigarette tax."

It is impossible to know how many people attended to the radio and television advertising, and more important, how many were actually influenced to vote yes. The state campaign coordinators felt that media support on the four Portland area television stations was vital to the election success. We do know that some of the television advertisements were viewed as far away as AshI and, on the southern Oregon border, but only those homes serviced by cable television. The only potentially measurable effect of the media campaign was in the Portland viewing area. Newspaper advertisements were not used On!y one ad was purchased in Corvallis, and this only because the laison chairman in that city insisted that local contributors needed a visible demonstration that their money was being used to help them in their county campaign.

In considering priorities in the media, we had a television budget to hit. Once that was hit, we had two options: In the metropolitan area there are four television stations. In Eugene cable television reaches 20,000 and in Corvallis 5,000. So we get a spinoff by using Portland television. Once we surpassed the goal of television advertising in this area we had to decide whether we would complement the television advertising by radio here or extend the television to the valley. We decided on radio here. Newspapers were never considered, because of the diama of television and radio We wanted to present the message emotionally which is not possible to the same extent in print. 56

Timing of the advertising campaign was planned to achieve maximum media saturation the last 20 days before the election. Increasingly longer advertisements were used as the election neared but the number 
remained fairly constant over the entire period. A few taped public information programs appeared on television in other parts of the state, but these were debates or information panels not funded or controlled by the State Committee.

Other State Committee Activity

Two other tasks were performed by the campaign consultants in the early stage of the campaign: (1) hiring a public opinion research firm and (2) arranging for speakers to explain the issues when requested by local civic groups.

Public speeches in political campaigns attract notoriously small audiences in Oregon, as in other parts of the nation. Campaign coordinators knew that the chief advantage to be gained through speeches was press coverage and free column inches in regular newspaper reports. In the beginning the only means of obtaining this kind of exposure was through appearances before civic clubs, public forums, and at "knife and fork" clubs. For this reason, Brad Davis spent a high proportion of his time in the first week or two of the campaign writing speeches. Another reason attention was given to public meetings was that in the early days of the committee's formation, meetings provided the only form of public legitimization. "The only way we had to communicate a message was to write a speech and run out and give it."

According to Brad Davis, his office was very selective in filling speaking requests. "We tried to go one for one; to pit equals against equals. When Harl Haas stepped in we'd get a Betty Roberts or a Vic. Atiyeh. People were paying our salaries for a win. Our credentials would not have been enough. We never accepted a speaking spot unless we 
knew in advance who the opposition speaker would be."

No formal press releases were issued from the Committee Against

Raising Property Taxes for two reasons: no money was available to hire a professional press man and the committee was getting what they considered was sufficient coverage through statements issues by state 59

influentials. For example, Jacob Tanzer, director of the Department of Human Resources, gave only two or three speeches during the 40 day campaign, to groups ranging in size from 15 to 35 persons; yet his comments were picked up and carried in newspapers in every part of the state and a large portion of the speech was reproduced in the OSEA newsletter which went to over 17 thousand state employees. 60

The firm of Richard Kennedy and Associates, in Eugene, Oregon, was 61 selected to conduct the opinion surveys. A total of four polls were taken, but only the first was compiled and tabulated according to the usual categories (age, sex, occupation, probable voter). The purpose of the survey was to determine voter awareness of the tax election, and the reasons they might favor or oppose such a tax increase.

The December poll showed 61 percent favoring the cigarette tax, 34.2 percent opposed, and 4.8 percent undecided. The most frequently mentioned reason for voting yes, was "property taxes will increase if the measure is defeated" (25.3 percent); the next most frequently mentioned reason was "smoking is dangerous and an increase in the cigarette tax will discourage smoking" (22.8 percent). Those opposed named "a cigarette tax is aimed at a small group of people" as the best reason for voting no (29.3 percent), "cigarettes cost too much al ready" (16 percent), and "the cigarette tax is a sales tax" (14.7 percent). (Table II) The poll also determined that 72.7 percent of the general 
TABLE II

KENNEDY POLL RESULTS ON ISSUES

COMBINED BEST REASONS FOR WOTING FOR THE CIGARETTE TAX

Reason

Percentage

Property taxes will increase if the measure is defeated. $18.8 \%$

$\begin{array}{ll}\text { Local schools will get less state money. } & 18.8\end{array}$

Smoking is dangerous and an increase in the cigarette tax will discourage smoking.

17.9

Out-of-staters help to pay our cigarette tax.

9.2

Local police and fire protection will be impaired.

8.3

College tuition will increase.

7.9

Out-of-state tobacco interests are trying to control

Oregonians

4.8

Not sure.

14.3

$100.0 \%$

COMBINED BEST REASONS FOR OPPOSING THE CIGARETTE TAX INCREASE Reason Percentage

A cigarette tax is a sales tax.

$62.7 \%$

A cigarette tax is aimed at a small group of people.

50.6

Cigarettes cost too much al ready.

37.3

Defeat of the cigarette tax will force economy in government.

24.1

Defeat of the cigarette tax will force economy in educational budgets.

22.7

Not sure.

69.0

$\overline{100.0 \%}$

Source: Richard Kennedy and Associates, "Attitudes Toward the January 18, 1972 Special Election" (Eugene, Oregon, December, 1971), p. 14-21. 
population was aware of the special election and 27.5 percent was 63 not.

Brad Davis said that the poll did not alter the decisions made by the coordinating team. Unlike the Bardsley-Haslacher poll taken 64 prior to the Tax Limitation campaign, the information was not seen by anyone during the campaign except the men making up the decision making triad. Davis explained the reason: "People need to think that work is vital to success." Had the early results been known to others involved, the committee feared that activity would have slowed and time would have worked against them. Also, the committee was never certain that the poll was accurate. "The best poll can be off by five percent 65

either way." Poll results obtained near the end of the campaign were phoned in: showing a 32 percent "yes" vote; 31 percent "no"; 47 percent "undecided."

The large increase in "undecided" voters was credited to confusion resulting from opposition claims about the property tax relief issue and the attorney general's warning of potential corrupt practices violations in television advertising and the Voters' Pamphlet. But Davis also felt that the later polls were more accurate. The director of the poll reported that if the "undecided" voters were el iminated, the "yes-no" percentage fell within one tenth of one percent of the actual vote cast. In a follow-up survey conducted by phone, the public opinion firm found that, in general, the "not sure" category reacted to their 68

indecision by not voting.

\section{Summary}

The cigarette tax issue was known to Oregonians prior to any 
formal campaign activity; the petition drive gained wide publicity as the sponsors gained notoriety through Corrupt Practices Act violations-hiring students to obtain voter signatures.

Tobacco wholesalers had initiated the petition drive and were successful. As a result, the governor called the legislature into special session. The 1971 Special Legislative Assembly likewise drew attention to the cigarette tax measure, especially when they passed a bill calling for two percent cuts to agencies funded out of the general state budget. Once the effect of cuts was known, both permanent and temporary interest groups began to initiate activity that resulted in the selection of three men to coordinate the campaign: one responsible for planning the media advertising, another attempting to organize and coordinate interest groups, and the third directing the fund raising drive from the governor's office.

Responsibilities of the State Committee was at once structured and fragmented: the shortage of time prevented decision checks with other groups. Major strategy decisions were made by only three men. But this same shortage of time prevented genuine coordination between workers in various parts of the state. As a result, a variety of independent coalitions formed and campaign strategy carried out by each group.

Chapter IV describes the strategies implemented by interest groups from the public and private sector, state officials, and elected leaders. It also is concerned with the manner by which the communication network expanded--including only a few interested individuals who talked with others of similiar concerns in the early phase. Finally, the chapter includes a description of the opponents and their campaign 
methods, an account of charges and counter-charges leveled by those on both sides of the measure, the ensuing confusion and outrage of uninvolved observers, and a reflection of all that had gone before-the final vote on January 18, 1972. 
Notes

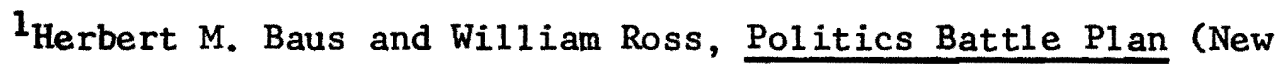
York: The Macmillan Co., 1968), p. 2.

2Jonas, p. 314 .

3 Ibid.

4During this writing, the Farm Bureau successfully initiated a measure that will appear on the November, 1972, general election ballot under the title, "Prohibits Property taxes for School Operations," called a sledgehammer approach to tax reform by the Oregonian, July 8, 1972. Every indication suggests anti-Ballot Measure Nine campaigning will exceed the Cigarette Tax campaign in terms of dollars spent, groups involved, and voter attention.

${ }^{5}$ Jonas, p. 314 .

"Cigaret Tax Election Raises Furor," Journal, January 17, 1972.

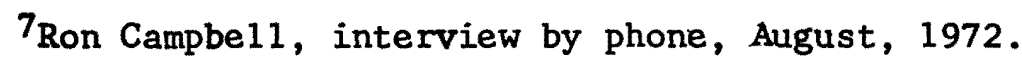

8 Ibid.

${ }^{9}$ Ibid; Rienke had posted a sign in the fair booth advertising a free drawing for a trip to Mexico to those who signed the petitions. A court order stopped the solicitation; it was deemed political advertising, and was without disclaimer.

$10_{\text {Ibid. }}$

11 office of the Attomey General, State of Oregon, interview by phone, July, 1972 .

${ }^{12}$ Richard Kennedy, interview by phone, May, 1972.

13Oregon State Employees Association, "OSEA Fact Sheet: Effect of Defeat of Tax Measure on Major State Programs" (Salem, Oregon, December, 1971). July, 1972.

14William Lesch, Associated Oregon Industries, interview by phone,

15Thomas Enright, Executive Secretary, Oregon State Employees Association, personal interview in Salem, Oregon, March 9, 1972.

16 Jacob Tanzer, Director, Department of Human Resources, personal interview in Salem, Oregon, April, 1972. 
${ }^{17}$ Alton King, student coordinator, Youth-Aged Coalition, personal interview in Portl and, Oregon, July, 1972.

${ }^{18}$ Lesh, interview.

${ }^{19} \mathrm{John}$ Danielson, Director of Legislative Affairs, Oregon Education Association, personal interview in Portland, Oregon, June, 1972.

${ }^{20} \mathrm{King}$, interview.

21 Thomas Rigby, Executive Secretary, Oregon School Boards Association, correspondence dated July 29, 1972.

${ }^{22}$ King, interview.

${ }^{23}$ Robert Davis, Assistant to the Governor, personal interview in Salem, Oregon, April 14, 1972.

${ }^{24}$ For a critical analysis of traditional campaign management duties, see Nimmo, p. 38-42.

25 Brad Davis, Free-lance Campaign Consultant, personal interview in Portland, Oregon, February, 1972.

${ }^{26}$ Ted Hallock, owner of Ted Hallock Public Relations Co., personal interview in Portland, Oregon, July 17, 1972.

${ }^{27}$ Robert Davis, correspondence dated July 14, 1972.

${ }^{28}$ Robert Davis, interview.

${ }^{29}$ Brad Davis, interview; Davis, Davis and Hallock make an interesting team: Hallock, as a Democratic State Senator and a likely candidate for President of the Senate at the 1973 Legislative Assembly worked closely with Bob Davis, the Republican governor's closest assistant. Brad Davis, as a free-lance consultant is more or less nonpartisan as his occupation requires.

${ }^{30}$ Brad Davis, interview.

${ }^{31}$ Ibid.

32"Pro-Tax Group Forms," Editorial, Gazette-Times, Corval1 is, Oregon, December 23, 1971.

33 Enright, interview.

34Danielson, interview. 
${ }^{35}$ Portland business executive, prefers that name remain unmentioned, interview by phone, June, 1972.

36 Lesh, interview.

${ }^{37}$ Robert Davis, interview.

${ }^{38}$ George Diel, Director of Publ ic Affairs, Chancellor's Portland Office, State Board of Higher Education, personal interview in Portland, Oregon, April 12, 1972.

${ }^{39}$ Wil Post, Assistant to the President, Oregon State University, personal interview in Corvallis, Oregon, June, 1972.

${ }^{40}$ Ibid.

${ }^{41}$ Diel, interview.

42Letter from Friends of Higher Education, Portland, Oregon, dated January 6, 1972 (obtained from George Diel).

${ }^{43}$ It should be pointed out that higher education did not officialiy engage in fund raising, except through their ad hoc committee associated with Colleges for Oregon's Future. The two groups have parallel interests but with different organizational structure.

44Robert Ingalls, editor, Gazette-Times, Corvallis, Oregon, correspondence dated July, 1972.

45 Brad Davis, interview.

${ }^{46}$ Thirteen different fliers (mimeographed), obtained from Brad Davis, February, 1972.

47 Ibid.

${ }^{48}$ Ibid; There is little evidence to show that campaign literature wins votes, although emotional appeals have proved effective in 1 imited cases: see G.W. Hartmann, "A Field Experiment on the Comparative Effectiveness of 'enotional' and 'rational' Political Leaflets in Determining Blection Results," Journal of Abnormal and Social Psychology, XXXXI

(1936), pp. 99-114, cited by Nimmo, p. 128 .

${ }^{49}$ Enright, interview.

${ }^{50}$ Nimmo, pp. 115-118. 
$51_{\text {Hallock, interview. }}$

${ }^{52}$ Ibid.

$53 \mathrm{Al1}$ radio and television advertising copy obtained from Ted Hallock, July, 1972.

\section{${ }^{54}$ Ibid.}

55 Wil Post, interview; the $\$ 58$ ad was placed in the Gazette-Times, and ran one day.

56 Brad Davis, interview.

${ }^{57}$ Ibid.

${ }^{58}$ Ibid.

59 Especially Governor Tom McCal1, Roy Lieuellan, L.B. Day, and Jacob Tanzer.

60 Tanzer, interview.

${ }^{61}$ In addition to managing the Kennedy public opinion firm, Richard Rennedy is an Oregon legislator serving in the House of Representatives (Democrat) from Lane County.

62"Attitudes Toward the January 18, 1972 Special Session."

\section{${ }^{63}$ Ibid.}

64"Property Tax Limitation Measure," Bardsley and Haslacker, Inc., Mid-October, 1968.

${ }^{65} \mathrm{Brad}$ Davis, interview.

${ }^{66}$ Richard Kennedy, owner, Richard Kennedy and Associates, Inc., interview by phone, May, 1972 .

${ }^{67}$ Brad Davis, interview.

${ }^{68}$ Kennedy, interview. 
CHAPTER IV

According to Erwin Bettinghaus, formal legitimizers often clear the way for persuasive activity carried out by campaign promoters: by lending their influence, or the weight of their positions, to proposals 20 they have publicly endorsed. In the cigarette tax campaign state officials seem to have performed just such a role. One important phase of the campaign was successfully secured when influentials endorsed the tax. Each official represented the top leadership of agencies associated in the public mind as apolitical, reputable, and performing services important to the general welfare. Elected officials carried out a similiar function. Public statements issued by the governor and by state legislators attempted to establișh the integrity of the proposal by creating a positive link in the mind of the voter between agencies of value and the state tax measure. In this sense the most important role officials and elected leaders performed was legitimization, clearly one of the most important functions of the persuasive process in politics.

\section{PUBLIC SECTOR MOBILIZES}

\section{Activity by Influentials}

The names of state officials and well known legislators provided the pro-tax forces with an aura of respectability and marked the campaign with a "prestige" stamp of approval. Of the officials in state agencies publicly endorsing the measure, Directors of the Department of Environmental Control and the Department of Human Resources were the 
most visible. L.B. Day, heading the newly formed state environment division, spoke to the Salem Rotary Club in early December on the topic of today's environment. In a response to questions posed by the press, Day outlined the expected effects on the environmental fight. The loss of revenue to a budget he considered already meagre might be permanently crippling. Day made no public appearances for the specific purpose of supporting the tax, but issued three press releases (December 6, 13, and January 12), the substance of which found its way into major newspapers 2 around the state.

According to Day, the DEQ became involved in the campaign on its own volition, not as a result of requests by campaign coordinators or others interested in passing the cigarette tax increase. His agency stood to loose a considerable sum if the tax went down to defeat and this was both the reason for his participation and the thrust of his 3 arguments.

Comments made by Day were not only picked up by the press in nearly every Oregon county, but excerpts from the releases were quoted in the newsletters sent out by the Environmental Council and the Oregon Shores Conservation Council. He thus created a communication linkage between public and private organizations drawing people together through their common interest in natural resources. 4 Day appealed to these people by saying:

Our budget is tight. If voters defeat the cigarette tax increase January 18 , the department won't have enough money to carry out the clean air plan adequately.

But he did not confine his remarks to the impact of a tax defeat on his own department. "Defeat of the cigaret tax would mean less money available for basic school support, with still further drain on 
property taxes."

Aside from issuing press releases, Day was in contact with the governor's office during much of the campaign, as was Jacob Tanzer, the Director of the Human Resources Department. Neither state official was directly associated with planning by the State Committee, however decisions made at the state level were definitely punctuated with issues and themes that had been recommended by the two men. Tanzer suggested to Brad Davis, "certain types of scenes, ideas from our institutions" which were adopted and used in the filming of campaign ad8 vertising.

The early thrust of the formal state campaign was not popular with Tanzer. It was his feeling that rather than discuss the fiscal impact of a tax loss by saying that money could be taken away from " $\mathrm{X}$ " group, it should be stated in terms of loss to "X" program, "and by program we mean programs for children and programs to assist people in their efforts to get themselves off the tax rolls. Dollars are not abstract. Dollars have real gut meaning in the ability of the state to heal broken lives and when you're talking about tax dollars, it is really those lives you're talking about." 9

Tanzer commented in an interview that there is a fine line between "scare tactics" and "facts put in human terms." He did not approve the early "sloganeering," used by both camps, the "simple little concepts" emphasized over the significance of cuts to programs important in human lives. "I am perfectly confident in the electorate that if the facts ever sink through, people will vote the right way." 10 In private conversations with some legislators who were going to oppose the measure, Tanzer obtained an agreement that they would remain silent. 
"Some were hung up on it being a sales tax and that this would hurt the poor. It was pointed out that failure of the cigarette tax would hurt the poor and they shut up."

Radio and television advertisments did reflect the Tanzer philom sophy and there is no doubt about the importance of his role in the campaign: as an advisor behind the scenes, and as an influential in the publ ic eye

Other agency directors within the Department of Human Resources performed different roles. Clarence Jones, Director of the State Economic Opportunities Office said that while his office did not solicit votes or action, his field people did. "We couldn't have staff paid by federal funds involved in this," ${ }^{12}$ but through non-federal staff members, fliers went out to over 30,000 people in the Community Action 13

program. Jones said his office pulled in representatives from local CAA volunteer boards for an informational briefing on what happens to a tax dollar in Oregon. "We made no pretense of knowing where the tax cuts would come--we told them where they could come. Health and welfare stood to take the brunt of the cuts." 14 After the briefing, the CAA volunteers were to stimulate voters to go to the polls, appealing to welfare recipients, the disabled, and minority groups--sections of the population other interest groups would not reach.

Mrs. Edward Hughes, coordinator of the State Program on Aging, gave "technical assistance to the State Council for Senior Citizens who had endorsed passage of the cigarette tax." ${ }^{15}$ She cooperated with Mrs. Shephard and Jack Nelson in distributing literature to senior citizens assisted by her department. 
Labor Commissioner, Norman 0 . Nilsen recommended passage too, but "with mixed emotions." Beyond a grudging public endorsement, he did little.

$$
16
$$

In eastern Oregon, Thomas Young, chairman of the Oregon Liquor Control Commission and former state representative from Baker and Grant counties, made at least one public speech that was covered by the press. His appeal for "yes" votes was based on the measure's "freedom of choice" character, but otherwise his speech was, in general, directed toward educating the audience about the provisions in H.B. 3064 .

Roy Lieuallen, chancellor of the State System of Higher Education, spoke to the Portland City Club on December 17, and like Young, was quoted in newspapers the next day According to the coverage of the Grants Pass Daily Courier and the Portland Oregonian, the text of his speech argued the state's severe financial crisis:

Some of my colleagues have tried to persuade me that it is not politically wise to be so candid as to say a vote for the cigarette $t a x$ is a vote for education. However, passage of the cigarette tax is at least a partial solution to our financial emergency. Should the cigarette tax proposal be defeated in January, and if current legislation is implemented, it will become necessary to cut back an additional 2 percent of our general fund appropriation, or about $\$ 2.7 \mathrm{mil}$ lion. Added to our $\$ 4$ million reduction for next year, the full cut thus totaling $\$ 6.7$ million or nearly 7 percent of our total operating budget... and, of course the primary vote in May on the income tax could add another $\$ 2.7$ million to that figure. 18

The chancellor's office al so participated in the campaign, as noted earlier, by alerting administrators in each of Oregon's colleges and universities of the state of financial contingency threatening the state system and requesting their assistance in passing the cigarette tax.

He too was in contact with the State Committee triad, although less 19 frequently. 
Officials Day, Tanzer, Young and Lieuellen appeared in the early weeks of the campaign, but there was almost a total absence of press 20

statements or public speeches in the closing days. As early legitimizers their function was chiefly to endorse. Only secondarily did they fulfill an informational role, one which was attempted by other influentials in the state.

\section{Blected Officials}

Numerous state legislators were involved in making public speeches and in initiating activity on a state and local level. In a letter to the editor appearing in the Oregonian, Senator Hoyt (R-Benton, Polk) summarized the reasons for legislators involvement:

Remember, the Legislature has gone over the governor's austerity budget twice making substantial reductions, once in the regular session and again in the special session.

Some legislators voted against referring the cigarette tax at an early special election because they preferred income tax reform, a state lottery, or the temporary expedient of accelerating the withholding tax on incomes. Some admittedly voted against it for political reasons. . .

No legislator questioned the need for additional revenue.

Senator Jason Boe (D-Reedsport), spoke on every major campus in

Oregon, explaining the financial need argument. "My analysis of the preelection needs was to mobilize the campus and the new voters; I believe that this was the swing vote." ${ }^{22}$ He also addressed groups in Roseburg, Coos Bay, Florence and Portland. With Representative Mary Rieke (RPortland), Boe conducted a long information session before the Legislative 23

Affairs Committee of the Portland Chamber of Commerce. To the Florence Rotary Club, Boe cited the "steep price in human suffering and hardship," that would follow the tax defeat.

In southern Oregon, Senator L.W. Newbry (R-Jackson) gave numerous 
talks favoring the measure and in addition wrote the explanation appearing in the Voters: Pamphlet, commended by secretary of state Clay Myers as being one of the rare "responsible" statements appearing in the much maligned special election pamphlet. In the pamphlet Newbry stated that . options open to the legislature were severely limited, explaining the "two plus four" plan which called for a two percent cut in all budgets for the first year of the biennium and a four percent cut in the second 26 year.

In Klamath Falls, Representative Fred Heard (D-Klamath Falls), spoke to an audience at Oregon Technical Institute, pointing out that while he voted against an increase in cigarette taxes at the regular and special sessions, "the fiscal picture has changed" partly as a result of actions by Congress on income tax exemptions and deductions, and partly as a result of the wage-price freeze.

In the most populated area of the state, the valley region, a great many legislators were expousing the issues. In Portland, Representative Frank Roberts (D-Multnomah), spoke to the North Democratic Forum and the Gresham Chamber of Commerce upon the request of the State Committee coordinator, Brad Davis, and the OEA-OSEA leaders respectively.

Senator Edward Fadeley (D-Lane), cooperated with the governor's office and the Joint Ways and Means Committee in their request for support. He appeared six times in Lane County in behalf of the "yes" forces, including a half-hour televised debate. Fadeley shared the platform with Bob Davis in behalf of the proponents, against Senator Harl Haas (D-Portland) and Representative Keith Burns (D-Portland). In the debate, broadcast over KRZI-TV, Fadeley said: 
If the tax is approved, Oregon will still be 14th from the bottom among all states in the amount of taxes on cigarettes. Forty percent of the current Oregon cigarette tax is paid by out-of-state residents who bootleg cigarettes home. 30

The debate was reported in a three column spread in the January 8, Sunday edition of the Eugene Register-Guard, reaching a potential audience of 53,541 .

Representative Jack Ripper (D-Coos), gave at least four speeches on the Oregon coast: to teachers groups, public employees, the International Woodworkers of America locals, and the Central Labor Council of Coos County. He characterized his role as both a legitimizer and as an 31 information source to the general public. Like the speeches made by other legislators, Ripper's appearances were covered and reported in the press.

In eastern Oregon, House Speaker Bob Smith (R-Burns), told an audience that "people will suffer property tax relief loss" if the tax 32

is defeated. Stafford Hansell (R-Umatilla) spoke to the Hermiston Rotary Club saying the tax increase "will be necessary to maintain many 33 state government services."

The chairman of the Legislative Interim Committee on Education, Senator Victor Atiyeh (R-Washington), told voters that "earl ier budget cuts were painful and drastic, but if the cigarette tax fails, the situation in my opinion will be grave."

Representative William Gwinn (R-Albany), a member of the Joint Ways and Means Committee which oversees budget needs, and a member of the Oregon Emergency Board, reassured Oregon State University engineers who were concerned about fund reduction on research then under way on a 
field burner, but did say that the cigarette tax money was important 35

for related research at the development center. In a "speakers circuit" swing later in the campaign, Gwinn provided a modicum of measured reason, saying that "campaign claims on both sides of Oregon's cigarette tax issue are exaggerated. There's been a lot of illogical hypothesizing." His argument in favor of the tax was based on temporary relief 36

in a crisis situation.

Many of Oregon's legislators participated in public debates. One such appearance was in Albany under the sponsorship of the Committee for Progress Through Law, an ad hoc arm of the Benton-Linn Economic Opportunity Council. Senator Hector MacPherson (R-Oakville), argued the pro side against Alice Toland, president of the Linn County Taxpayers Protection Association and Ron Campbe11, the Portland teacher who had recruited students to circulate petitions in the referendum drive.

Legislators who opted to publicly support the cigarette tax were about equally divided between the two political parties: Newbry, Smith, Bivers, Gwinn, Atiyeh, Carson, Johnson, Rieke, and Howe from the Republican camp; Fadeley, Lang, Boe, Ripper, Roberts, Cole, Heard, and Byers from the Democratic. Arguments ranged from "band-aid" solution for longrun fiscal needs, to appeals designed to reason the impact of special budget cuts to special programs. Party partisanship seemed forgotten as leaders in the two parties appeared on the same platform in behalf of the measure.

Governor Tom McCal1

Members of the Oregon legislature were joined in their public endorsements by their independent Republican governor, Tom McCall. The 
governor issued a press release immediately following the adjournment

of the special session urging that the cigarette tax be approved. At every available opportunity he spoke in behalf of the measure.

In eastern Oregon, at the annual Milton-Freewater Chamber of Commerce awards banquet, McCall spoke to over two hundred, structuring his remarks around two upcoming ballot measures. First he appealed for support of a bill important to eastern Oregon farmers which would permit the state to issue bonds for the purpose of making loans to farmers for irrigation. His other appeal seemed at that time important to few-an "all-out" plea for passage of the five cent a pack cigarette tax increase:

The cigarette tax is more than dollars and cents. It is a symbol--of what $k$ ind of situation we face, what small moves we must make--what kind of concern we must now evince.

If we lose the cigarette tax, it will be more than revenue that goes with the wind. We will have lost the momentum to achieve. The people of this state must stop retreating.

This is the edge of the pregipice. Our heels are hanging over. There is no backstep.

Using an analogy likening public voting patterns with the "group will to survive," McCall spoke earlier in the day to Stanfield High School students. To this group as well, the governor spoke in favor of the tax and went on to express the opinion that "the people of Oregon have a phobia against a sales tax, but it is a bona fide, necessary 41

form of public finance."

As the elected official charged with the responsibility of proposing a state budget that meets the needs of all agencies of state government, McCall had seen $\$ 36$ million deleted from his original budget proposal by the Ways and Means Committee at the regular session. The additional cuts made necessary by the successful referal of the 
cigarette tax eroded a budget he already had deemed inadequate. In a state where the legislature and the people are co-equal legislative organs, each able to make, repeal, or modify law on its own, the governor is no more powerful than the support he can win for his programs Moreover, the governor has no power of veto over legislation passed by the people; once the tax was referred the only course available to McCall lay in using the influence and prestige of his office in a persuasive attempt directed at the voters.

Fearing partisan identification in the public mind, McCall did not make extensive persuasive efforts, but did issue an early press release threatening another special session if the January 18 th election negated the cigarette tax. And he exerted the influence of his office in personal contacts to legislators, lobby groups, and in some cases, newspaper editorial staff; encouraging support both by monetary means and public endorsements.

The governor's participation took various forms not the least of which was the "loaned" activity of his assistant, Bob Davis, and the tacit approval of his office for participation by other agency personnel. Public appearances and press statements by the governor extended the communication chain. When the governor appears in Wheeler, population 261, he makes news. When he issues a press release, the media attends.

\section{Economic Interest Groups}

The discussion thus far has considered the involvement of influentials from agencies perceived by their directors as most seriously affected by a negative election outcome. Their appeals were directed at a general audience that was expected to support the notion that 
human and environmental resources were a necessary and desirable function of government. Elected officials likewise struck at constituent interests. In contrast, the activity of large public and private organizations appealed to clearly definable and relatively more narrow economic group interests--"pocket-book" interest of the people from whom they drew their membership.

Changes in the Oregon constitution providing for legalized political activity by state employees was an important factor in both the visibility of influentials from state agencies and the utilization of state employee organizations to promote the cigarette tax measure. Prior to 1967, public employees were not permitted to contribute anything of value--time or money--to any sort of political campaign. In a bill titled the Corrupt Practices Amendment, the Legislative Assembly repealed all sections of the constitution inhibiting political action by state employees excep! those relating to coersion. ${ }^{44}$ In the 1971-72 cigarette tax campaign, public employee organizations not only participated but used their organizations in an overt attempt to influence voters. In other parts of the nation, activity by public employee groups has resulted in the winning margin in a close election and certain developments suggest that this was also true in Oregon.

Of the economic interest groups in the public sector, the Oregon State Employees Association was the most active. Beginning their formal activity while the 1971 special session was still in progress, the OSEA was involved in nearly every phase of the campaign: as legitimizers, as initiators of the campaign on a state and local level, as information source to OSEA members, and as consultants in some aspects of general decision making on the state level. 
According to Thomas Enright, instigator of OSEA participation, the primary objective was to sell state employees and only incidentally to convince the general public. After obtaining the approval of the OSEA board of directors, Enright sought the cooperation of other state employee organizations including the Oregon Education Association, Oregon School Employees Association, Chancellor's office of Higher Education, Oregon School Boards Association, State Department of Education, Oregon Community Colleges and the American Federation of Teachers. Of these groups, two (the OEA and OSEA) maintained close contact and co-sponsored 14 public meetings in every region of the state where there was a large concentration of association members. The meetings were directed to the membership of the OEA and OSEA but were al so held open 45 to the public.

The meetings were poorly attended according to Enright. Those who did attend were either strongly for the measure or strongly against it. "Not many came who were uncommitted." 46 Although the audiences were small, press and television coverage extended the visibility of the state employee organization and their participation in the campaign. The presence of either a state senator or representative on the same platform with nonpartisan organizational leaders made news. In Klamath Falls, an isolated city in southern Oregon, television cameras recorded and carried over five minutes of Representative Fred Heard's speech in the 47 evening news broadcast.

An overriding "survival" issue dominated the OSEA arguments--parallel to the arguments originating in the State Committee headquarters but with a lesser degree of emotional loading. Enright was deeply concerned about the inaccuracies and emotionalism that characterized the early 
materials disseminated by the State Committee and decided that the OSEA should develop their own. "Our people wouldn't stand for exaggeration. They were not pleased that we had decided to promote the issue, but after awhile they became educated to the reality of the situation. The results show at the polls. Where we had a large portion of state employees, the margin was significantly greater."

The 1971-72 campaign was the first that the OSEA had been financially and editorially involved with. They had decided to sell their members early in the campaign so that opposition publicity would have a minimum influence. With this objective, newsletters were sent to members in 80 chapters. Seven thousand copies went to other non-member state employees. Communication carried out by the OSEA central staff also included individual mailings explaining the tax measure and announcing the meeting dates, and information in the form of a one page bulletin which organizational district representatives were requested to post on staff room bulletin boards. Even though Enright considered the activity of his organization "reaction strategy," poorly structured and weakly implemented because of the shortage of time, various printed material did reach the households of at least 17,000 state employees.

A special section of the OSEA News, January edition, carried four pages of information devoted to the cigarette tax election. A detailed description of the background on the tax election, written by Enright, included an eight-point evaluation of the potential effects of a defeat and the reasons the legislature elected to draft H.B. 3064. Summarizing, Enright said:

OSEA legislative representatives believe that the present fiscal crisis is real; that the automatic cuts in 
H.B. 3064 are no mere threat. As Governor McCall has said, defeat of the cigarette tax would be a disaster. The disaster can be averted if the 17,000 non-federal employees $i p_{0}$ Oregon and their families vote "yes" on January 18.

The second and third pages included (1) the complete text of Jacob Tanzer's speech delivered to the Washington County Forum, (2) detailed figures on revenue loss to each of the 13 community colleges; (3) anticipated job reductions at state institutions, and (4) costs to Oregon schools-quoting Dale Parnel1, Superintendent of Public Instruction, and Roy Lieuallen of the State Board of Higher Education. The final page provided a 1 ist of agencies and the cuts each could reasonably expect to loose expressed in dollars.

Participation in local OSEA chapters was spearheaded by the state organization. Enright said that approximately 50 local chairmen were named. In Benton county, an area where many groups were working together, the Oregon State University campus chapter named Professor Myron Cropsey as chairman. In cooperation with the sister chapter of OSEA, composed of classified personnel, and faculty members belonging to the American Association of University Professors, Dr. Cropsey organized and directed "approximately 92 persons" whose task was to inform friends and neighbords in a person-to-person telephone campaign. Each delegate was to contact at least 10 people and ask them in turn to relay the message to 51

at least five more.

Unlike OSEA membership, people represented by the Oregon Education Association did not have as much to loose. Whereas the OSEA interests depend chiefly on support from the General Fund, Oregon teachers and administrators obtain 70 percent of their district revenue from local property taxes. In spite of this lesser pocket-book impact, the OEA 
recognized that Basic School Support decreases would make impending salary negotiations more difficult. Further, the increasing number of school budget elections being defeated over the preceeding five years reflected a state and national property tax rebellion. "The taxpayer revolt" made the OEA legislative staff sensitive to the need for long-run tax reform and, as an intermediate and temporary solution, 53

the 1972 cigarette tax increase.

Members of the OEA staff worked jointly with the OSEA in publicizing and organizing the public employee meetings (Figure 3). Press releases were mailed to newspapers in the area where a meeting was to be held, cooperation of legislators in the area was obtained, and staff members made available to supplement the explanation of the issues by legislators and the OSEA staff representatives. Cecil Posey, executive secretary, and John Danielson, government relations director, divided speaking responsibilities, generally appearing on the platform with either Enright, or his assistant, Everett Stiles.

Legislative chairmen in local school districts were notified by the OEA central office of campaign needs and were used to inform teachers and encourage local participation. Direct mailings to the membership were not used but a list of OEA workers was provided to Brad Davis who in turn disseminated the State Committee's printed literature to Oregon teachers. Again like the OSEA, OEA directors were not satisfied with the emotive appeals used by the State Committee and developed their own "fact sheets," which included information sent in bulletin form to legislative chairmen, and a comprehensive edition of the OEA tabloid. Danielson estimated that "over 19,000 teachers received the news through one or more of the organizational channels." 


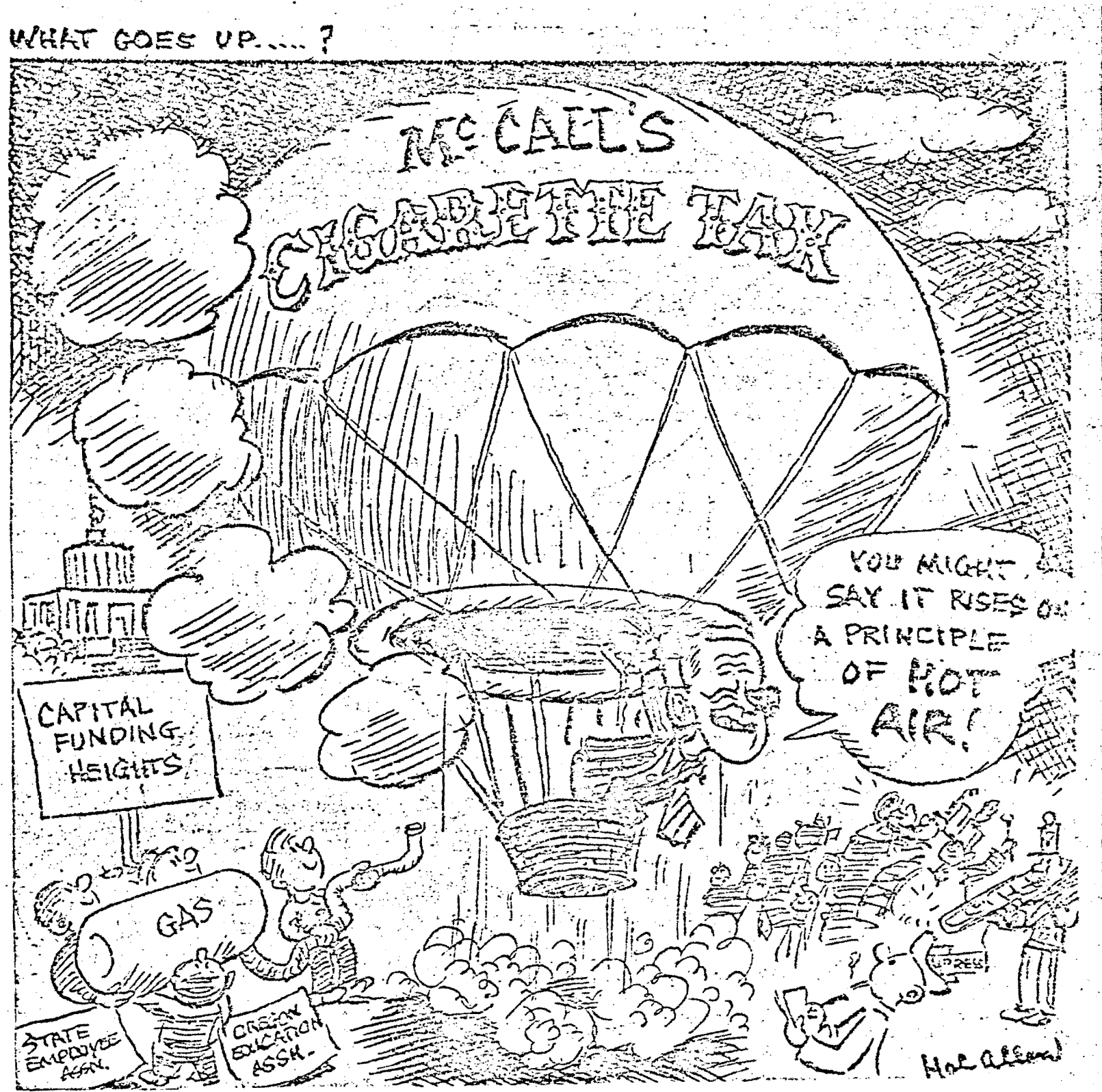

Figure 3. Editorial Gartoon, Oregon Journal, December 29, 1971. 
Activity by the state organization paved the way for other educators favoring the tax. Officials attending the twenty-second winter conference of the Oregon Association of Secondary School Administrators, an OEA affiliate, woted 90-55 to maintain their stand in favor of the cigarette tax after several members objected on the basis that a resolution urging stronger smoking laws for minors was inconsistent with public endorsement of the tax.

\section{Activity of Other State Organizations}

The Oregon School Board Association and Oregon AFL-CIO endorsed the measure but played a relatively minor role in the total campaign. They did provide members with information through their regular house organs, but according to Thomas Scanlon, public information officer of the AFL-CIO, "We did no more than asked to do." 57 Thomas Rigby, executive secretary of the OSBA, recommended endorsement to his state board. Robert Ridgley, OSBA president, said on January 8 , "We cannot stand any cuts in an already meager state school aid budget," and on January 10, the Hilhi School Board in Washington County, and the Enterprise School Board in Wallowa County, passed endorsement resolutions. ${ }^{60}$ Many other local school boards came out in favor of the tax, perhaps as a result of the example set by the state organization.

The League of Oregon Cities and Association of Oregon Counties mailed informational memos to city and county government administrators notifying them of the dollar cuts to their agencies. No attempt was made to influence public voting behavior by either of these groups. "The cigarette tax had no direct effect on city government activities or cuity government revenues, and therefore was not deemed an appropriate subject 
for activity by the league."

61

utive secretary of the Association of Oregon Counties provides substantially the same information, only substituting "county government" for "city government." 62

Oregon Community College Association Executive Director, Dr.

Donald Sheldon, cooperated with the State Committee by requesting donations to the campaign effort through letters mailed to administrators at each of the Oregon campuses. The only publication compiled by the OCCA is distributed only five or six times a year and includes primarily information of general interest to community college personnel. The tax measure was mentioned briefly in one such bulletin, but according to Dr. Sheldon, the circulation is limited and therefore not an appropriate medium for persuasive communication. Further, the organization is supported by state funds, unlike most of the membership organizations in the public sector, is relatively new on the Oregon scene, and has a small, apolitical staff. Its attempts to influence was accordingly limited.

The efforts of higher education, on the other hand, were not restricted. The ad hoc committee, Friends of Higher Education, has already been mentioned in connection with fund raising activity. They not only raised proportionately more money, they did so by drawing in businessmen and others around the state who were interested in preserving quality in higher education at the state schools. "Get a man to give dollars, and you have his vote," reasoned Wil Post, laison campaign chairman on 64

the Corvallis campus. In Eugene, the Lane County Referendum Committee obtained community support and donated over $\$ 2,000$ to the campaign effort. 
This was the first Oregon election to be held under the new law requiring that campaign expenditures be made known 10 days prior to the election. With the contributions made by higher education generally known, still another source of influence emerged in the growing chorus of campaign voices. The citizens of Oregon were made aware of the educational community's committment to passage of the cigarette tax.

\section{Summary}

An answer to the question of who, in the public sector, generated the most in the way of visible campaign activity would clearly be the three major employment groups: the Oregon State Employees Association, the Oregon Education Association, and higher education through its ad hoc interest group, Friends of Higher Education. In sum, the groups provided leadership by utilizing personal and mass communication channels: public meetings, printed literature, personal influence through direct personal contacts, and printed and electronic mass media indirectly through news coverage of organization sponsored public meetings and financial contributions.

\section{ENDORSEMENTS}

Public endorsements constitute important campaign activity and 66 sometimes provide the important difference in success or failure. During the short cigarette tax campaign, newspaper morgues filled with endorsements from each side of the political continuum and from organizations representative of nearly every phase of Oregon 1 ife. The following section deals primarily with general endorsements made at the local level, support by private state organizations, and the important 
activity performed by the Youth-Aged Coalition.

\section{General Endorsements}

In Klamath Falls, one of the few areas in the state where the local paper took an editorial stand against the tax increase, the Klamath Fal ls Chamber of Commerce voted unanimously to endorse the measure Officials from that organization said the endorsement was based on the "critical condition" of the state's finances due to fis68

cal imbalance. The Hillsboro Chamber, North Clackamas County Chamber of Commerce, and Eugene Area Chamber all reported endorsement, as did 69

other city groups scattered across the state.

As the campaign moved forward, reports began coming in about an increasingly greater variety of groups making public their approval.. Wallace McCrae, president of Blue Mountain Community College in eastern Oregon, emphatically stated his support, fearing a decline in educational quality. if the two percent cuts went into effect. 70 George Analla, of the Oregon Tax Research publication, and Herman Kehrli, director emeritus of the Bureau of Government Research and Service at the University of Oregon, distributed studies clarifying the fiscal impact on the state budget that, while not direct endorsements, had strong positive influ71

ence. Kehrli's remarks were reprinted in their complete form in the strongly pro, Oregon State University paper.

Senator Robert Packwood responded to a question on the tax posed by newsmen, saying, "I'I1 support it, but not with the feeling that we must have it or civilization will come to an end."

Senior citizens from Columbia county adopted a resolution called a "Prepaid Health Plan for the Smoker," widely quoted in the Oregon press: 
Whereas a good share of these victims will need tax support to. pay all or part of their medical expenses and living costs, whereas, cigarette smokers have ninetyfive percent of al 1 lung cancer and emphysema, be it resolved that Citizens of Oregon pass the cigarette tax bill.

By doing so--sick smokers who end up on welfare, rehabilitation, and unemployment or other tax supported state services will have had the opportunity to help prepay these expenses. 73

In Lane county, six of the seven members of the Lane legislative delegation, both Democrats and Republicans, approved a resolution urging passage of the tax increase:

Having watched and participated in the many millions of dollars of cuts in the state budget, and the inadequate funding of local units of government, we believe further cuts cannot be made in these areas.

We believe further cuts in state support of local government will inevitably result in increased property taxes. Based on existing laws, the loss of local property tax relief in Lane county could be over $\$ 1$ million next year.

Intentional inaccuracies used in this election, including statements in the Voters' Pamphlet, must be countered. A "no" vote will reduce property tax relief. It is a falsehood to suggest otherwise.

A "no" vote will increase property taxes. 74

In contrast to the Oregon Farm Bureau, one of the few interest groups who opposed the tax in a public statement, the Oregon State Home Builders Association voted to support it. The association president, B.D. Greene, said, "it was very clear that defeat of the tax would place an increasing burden on property taxes."

The State Housing Council, an appointive committee selected by Governor McCall, al so urged voters to approve the cigarette tax increase, again, because of the property tax linkage to the ballot measure. 77

An extremely conservative journal, the Oregon Voters Digest, wrote "we oppose discriminatory special sales taxes on principle, but this particular cigarette tax increase should get a "yes" vote," 
because of the severe time limitations involved in obtaining any other 78

form of state revenue. Their support and the unanimous support of college and university alumnus papers provided more evidence of bipartisan, conservative-1 iberal approval .

\section{Summary}

Even where endorsements were not forthcoming, little opposition surfaced. Only three major newspapers (subscription 10,000 or more) came out opposed: the Medford Mail-Tribune, Klamath Falls Herald and News, and Ashland Daily Tidings. The endorsements, whether they were in response to membership pressure or the result of speeches by prestigious citizens, added to the general network for delivering the campaign message, and to some extent may have created a bandwagon rationale for ever more groups to privately support the cigarette tax. In a political campaign to win public office, endorsements are used to convert highly impersonal propositions into personal issues. In a campaign where there is no candidate, no popular appeal, no personal ities; speeches to Rotary and Chamber of Commerce groups are doubly crucial for campaign organizers. If "many voters judge a candidate by the people who endorse him," 80 then perhaps it is also true that when no personality or popular appeal exists, a group which endorses the abstraction of a ballot measure, provides voters with an even greater measure of direction.

At any rate, on an impersonal measure like the tax referendum, the proponents need to create a situation that would attract public attention. The wide variety of endorsements, along with other developments to be described in another section, served this purpose. Even when voters remained unaware of the approval of any one group, the group 
itself, if consensus was genuine, served to extend the influence of the campaign.

\section{Business Interests}

In 1969, Oregon business interests had presented a united front in support of the sales tax, but in 1971-72 their enthusiasm for revenue measures was 1 imited to somewhat grudging financial contributions and the loan of a few "executives" to the campaign committee. The re is good evidence to suggest that what little support did materalize from this group reflected the implicit threat of increased corporate taxes. One informant, whose organization contributed $\$ 1,000$ to the campaign, expressed the opinion that any future dole would be subject to considerably closer scrutiny by his board of directors, in part because of the bad publicity resulting from inaccuracies emerging from both camps, and in part because of a negative corporate reaction to "blackmail" by the governor's office.

Whereas many corporations were asked for manpower, only a few provided it. These were the "invisible men," working behind the scenes with other volunteers, with civic clubs, and in whatever way the State Committee decided to use them.

An Associated Oregon Industries employee, Bill Lesh, "on loan as a volunteer," urged students, college professors and other state and local employees to volunteer their time going door-to-door as well as making whatever financial contributions they could. "Oregon's 100,000 public employees and their families can have a major impact on the vote if they go to the polls," said Lesh to a Portland Chamber of Commerce 82 meeting in December. This public statement was strong, but the sole 
visible evidence that business employees had any part in the campaign. Apparently the State Committee had divided responsibilities among three volunteers. Don Arvidson of Northwest Bell Telephone Company, made a limited number of contacts in Clackamas county; Les AuCoin, state representative and public information officer at Pacific University, worked Washington county. Bill Lesh, loaned from AOI, was responsible until the first of January, for Multnomah county. 83 Scott Montgomery, paid assistant to Brad Davis, was assigned the southern part of the state and worked with $\mathrm{Al}$ King and other students in establishing contacts 84 there.

The goal of these volunteers was to contact as many opinion makers as possible, obtain from them names of workers, potential contributors, and gain their public or private endorsement. Lesh described the activity as a "communication task": trying to convince leaders to "get invol ved."

Brad Davis had hoped to appeal to business interests more strong1y. The State Committee felt that the business community would carry arguments to their own employees--specifically the argument of property tax relief. There is no evidence that they did. They had little financial stake in the outcome of the election and very little to say about the manner in which the campaign was run. It can be assumed that the transmission processes available through private enterprise were not used.

\section{Youth-Aged Coalition}

The woman originating the youth-aged merger, Ruth Shephard, was guided by two motives: (1) public visibility for senior citizens, and 
(2) creating a situation whereby the elderly could actually work to good purpose for a positive "cause."

On November 10, 1971, prior to the special legislative session, the Oregon Council of Senior Citizens had issued a press release objecting to the budget balancing strategy proposed by the Joint Ways and Means Committee. The Legislative Committee of the State Council, as well as representatives of several other organizations with statewide senior citizen membership, sought to "maintain tax relief" by encouraging the Ways and Means Committee to "keep faith with the principle of "ability to pay" as reflected in the present tax relief law, and not to cut any part of the assistance that was promised last spring."

It was on the basis of this senior citizen sentiment that Mrs. Shephard approached Alton King, then executive secretary of the University of Oregon student body president, a 27 year old student who had worked with Mrs. Shephard on a variety of senior citizen projects. It was upon her recommendation that King drafted the letter to Jack Nelson. In the letter, the student leader suggested a coalition of students and senior citizens, the possibility of media visibility based on the unusual image such adiverse and frequently opposing cooperation of interest represented, and promised student cooperation from existing campus organizations throughout the state. He closed the letter to Nelson by saying, "Let us make senior citizen power a fact."

On November 22, Nelson mailed a reply to King's offer, saying:

Senior citizens are much interested in today's youth and the "new" voters--we salute your fine effort to be involved in such a responsible way, and look forward, very much, to working with you. 89

From this point on, cooperation between the two age groups imade 
news. But the coalition was more a myth than a reality, perpetuated by aish on the part of both $\mathrm{King}$ and the State Commit coordinators to maintain the appearance of a popular front organization. A somewhat 90

limited mailing was accomplished by the senior citizens., but for the most part the participation by the State Council was 1imited. With the sanction of officers of the council, press releases and correspondence written and distributed by the youth, went out under the name of the coalition. Throughout the campaign, the "united" front maintained:

Senior citizens have found very good helpers with these young people, in our mutual fight to pass the cigarette tax and hang on to the property tax relief that was promised us by legislators 1 ast spring. Seniors have banded together in this effort because we know that the state can't run, just like we haven't been able to run, on inadequate incomes. 91

Campaign leg work was done by the students. Under the direction of King, a state-wide communication network between student leaders at each state and community college was established. Prior to the second coalition meeting in November, King had written representatives from Portland State University, Oregon State University, Portland, Chemeketa, and Lane Community Colleges, and South Salem High School. Someone from each of these campuses was present at the meeting in the governor's conference room in Salem. Following the meeting these same student leaders provided the momentum for activity on their own campuses; distributing leaflets sent them by King and Mike Park (also a student at the University of Oregon), and providing speakers to explain the measure to any local group requesting information.

As part of the responsibility of student coordinator, King wrote a two page informational essay, several sample "letters to the editor," 
and a speech text--distributed to the "prime movers" at each of the state colleges and universities. In both the essay and the speech, King cited (1) the two percent cuts to state programs provided for in H.B. 3064 , (2) the compounding four percent cuts threatened by failure of the federal and state income tax separation measure, and (3) the cigarette tax as a "user tax." He pointed out to the students the costs to the state created by cigarette smokers in increased state building costs because of higher insurance rates, and the reforestation of burned timber land as the result of smoker carelessness.

In addition to the materials sent to over 50 student leaders, King distributed the State Committee's printed literature directly from his office in Lane county and by providing a 1 ist of students to Brad Davis who del ivered additional packets of material. The student leader, like the leaders of the large state interest groups, expressed displeasure with the contents of the leaflets. "It really hurt us when we used them. People are not fools."

On January 13, King addressed the delegates of the Inter-institutional Union of Students of the State System of Higher Education (IUSOSSHE) meeting on the OSU campus. Delegates decided to distribute the "fact sheet" on the negative impact of a "no" vote, but stopped short of formal 95

endorsement. King said that the agreement to disseminate the State Committee 1 i terature was reluctantly given.

According to King, the most significant contribution his committee made in the campaign was the personal contacts: to people new to a state campaign, to editors and electronic media personnel in behalf of the coalition, and to community and civic leaders. In a three day swing 
through southern and western Oregon, King and his assistant, Mike Park, contacted people in Medford, Grants Pass, Roseburg, Coos Bay, North Bend, Coquille, Reedsport, Newport, Florence, Tillamook, Wheeler, Seaside and Astoria. Mrs. Shephard had written to senior citizens in these areas alerting them to the student visit, and Brad Davis made available names of media contacts. As a result of the tour, many newspapers and civic clubs publicly endorsed the ballot measure and applauded the coalition effort. Student and faculty members in Ashland, : Reedsport, and Astoria began to make public speaking appearances, and a "great many students got busy handing out literature by the gross." On many of Oregon's state campuses student leaders were busy. In Corvallis, Oregon State University student body president Ron Wilkinson voiced his support of the tax measure and organized students in a large registration drive on campus. 98 Forty or more students were involved soliciting votes, distributing information materials, providing transportation to the polls and speaking to Corvallis, Lebanon and Albany civic organizations as well as housing groups on the OSU campus. Reflecting the OSU student and faculty interest, the campus newspaper, The Barometer, published a special election edition giving a full range of coverage to the special election.

The student council at Blue Mountain Community College went on record January 11, favoring passage, by a 12-1 vote. Tim Mabry, BMCC student body president said that the "student council is a representative sounding board of the opinions of the campus," and that students were busy distributing materials on campus in a demonstration of earnest sup- : 100 port.

Wally Lien, president of the Oregon Community College Student 
Association and current president of Chemeketa Community College, had made the materials available to Mabry. Additionally he circulated a special bulletin to students on his campus in which he stated.

Recent past tax defeats cause legislators to be extremely conservative about proposing future tax increases to provide necessary funds for programs. When state funds .. . are cut, it places additional demand for local property taxes. This demand, on top of regul ar demands usually causes hardening of the arteries toward the alternative source of revenue. The only remaining alternative is our tuition. If you are eventually planning on transferring to a four year college be advised that they rely even more on state general funds.

Even if you smoke, you can't afford the luxury of a negative vote on a fund source that pays half the cost of your education. . . . Make sure that all the voters you can get for the polls understand why a YES vote is of such urgency. 10

At Southern Oregon College in Ashland, student leaders were work-

ing with faculty. Also in Ashland, Pat Overhand, Ashland High School

student body president, attempted to involve those under 18 in distri-

buting literature on the tax. King said that parental support was

sought through the high school students but that time worked against 102

them and this effort failed.

Summary

Under the cover of the youth-aged coalition, King's committee was successful in distributing literature, obtaining press coverage of the coalition's activity, and in working with other student leaders in mobilizing activity on campuses around the state.

Following the election, the Eugene Register-Guard wrote in an editorial :

The youth vote is widely credited for the narrow passage of the cigarette tax increase Tuesday. That credit is due. But the young voters didn't do it alone. 
Bvidence is strong that older people teamed up with the young in a fortunate dual effort to keep Oregon from bankruptcy. 103

Mrs. Shephard commented after the election that while the elderly citizens of Oregon "dropped the ball" in actual campaigning, the objective had been met. As a group they "felt" involved, the Oregon public was made aware that elders could be a positive influence in events affecting all Oregonians, and the tax measure did pass. In this respect, the coalition was a success.

\section{THE OPPOSITION}

Campaigning originated by the anti-cigarette tax people is not of primary concern to this thesis. However it would be an error to suppose that there was no such activity. In one sense the referral drive can be considered the first phase of the opponents campaign to defeat the tax. Once the measure was placed on the ballot an aggressive campaign was launched, punctuated by hyperbole and inaccuracies.

In one of the few efforts to obtain legitimacy on the "no" side, Senators Vernon Cook (D-Gresham) and Harl Haas (D-Portl and) formed "Legislators Opposed to the Cigarette Tax Increase." The press coverage obtained by the announcement of a legislator's committee was extensive. Many papers quoted Cook as saying, "It's pure baloney" to say that state services would be irreparably crippled. "A special session could solve the financial problems of the state by quarterly state income tax reporting, and state tax reforms: increasing corporate income taxes; forcing out-of-state businessmen to pay their full share; taxing capital gains as ordinary income; instituting a policy of estimated tax pay105

ments by corporations and self employed." 
On December 28, Haas, Cook and Representative Howard Willits (D-Gresham), issued another press statement identifying their chief arguments: (1) defeat of the cigarette tax increase would force Republicans to adopt tax reform measures, (2) a special session was needed for reform, (3) the cigarette tax was a sales tax in disguise, and (4) it was a selective tax hitting middle and lower income families. Other news reports picked up an extemporaneous statement by Willits in which he said that "a higher cigarette tax would make the state more dependent on this type of tax and thus less inclined to discourage smok107 ing."

The majority of the legislators opposing the tax remained silent. Only a highly vocal minority made news. In a speech to a southern Oregon civic group, Representative Sidney Bazett (R-Josephine), said that weak spots in the state budget could be connected to absorb the 108

1oss. Another state senator, Thomas Mahoney (D-Portland), publicly opposed the measure, and in an editorial reply, the Corvall is GazetteTimes, chided him and attempted to reduce his credibility by naming him as attorney for the tobacco distributors who sponso red the referendum 109

and funded the opposition campaign.

Clyde Brummell, president of the Oregon Homeowner's Association, the only visible private membership organization coming out in opposition to the measure, said that his organization opposed the tax because 110

of its "selectivity." It was the homeowners association that had sponsored the initiative placing the Tax Limitation measure on the 1967 ballot.

Still another source of opposition emerged in what was a move to counter the popular pro-tax youth-aged coalition. Two committees 
surfaced. The Coos Bay World called it a "raft of opposition," but their activity began and ended in two $\$ 50$ page arguments appearing in the Voters' Pamphlet. "Students for Sensible Tax Reform" argued the discriminatory nature of the tax: "a miserable excuse for true tax reform and property tax relief," and "Senior Citizens Against Property Tax Increase" called the proposed tax "excessive, restrictive, and dis112

criminatory." The man named treasurer of the student committee was a young law student friend of Ron Campbell, organizer of the summer petition drive; the treasurer of the senior citizen committee was the law student's grandmother. Campbell wrote both ads.

Kenneth Rinke, the man who initiated the referendum drive and a lobbyist for the tobacco distributors, surfaced only once--as a contributor of $\$ 1500$ to the "vote no" war chest, representing 10 days of time donated at $\$ 150$ a day. He did far more but all of the activity was behind the scenes. He planned the media campaign, hired the public relations advertising firm, and supervised all strategy decisions. 114

Sumnary

The enemy forces included then, five state legislators: one (Mahoney) employed by the tobacco interests, and four private citizens, two of whom were employed by the same people (Rinke and the attorney for "Oregonians Against Any Sales Tax" committee). And so the war was fought on both sides of the battle line by people with similiar motives: economic self-preservation.

\section{CAMPAIGN HEATS UP}

By early January, the campaign became heated. Both those in 
favor and those against the tax began making increasingly stronger charges and counter-charges. Arguments were deliberately and systematically selected to influence opinion by methods calculated to call forth emotional reactions in the voter's mind. It would be a euphemism to call what became daily campaign exaggeration anything but pro115

paganda.

Most of the charges revolved around a statement made by the anticigarette tax campaigners that a "yes" vote on the increase would mean a cut in property tax relief--an argument that was in no way accurate. Statements to this effect appeared both on television and in radio advertisements and in the anti-cigarette tax arguments found in the Voters' Pamphlet and campaign brochures. Newspaper ads carrying the slogan, "Beware of Tricks," alluded to the same issue (Figure 4).

When the "Vote No" advertisements appeared, L.B. Day reacted. In a press release issued on January 4, Day called the television ads "one of the most misleading pieces of sloganeering and scare tactics I've ever heard." He went on to say that "such outrageous propaganda might very well deprive Oregonians of clear air and water."

$$
118
$$

Day was quoted on Tuesday. Wednesday, Cook responded by calling state officials, "prostitutes of the governor who are being paid to tell lies about the governor's sales tax." 119 The governor's assistant, Bob Davis, shot back "The truth is that property tax relief will be cut only if the cigarette tax is defeated. The statement made by Cook, that my part in this campaign is illegal, is absolutely outrageous and untrue."

On the same day, Attorney General Lee Johnson said that he had seen one of the ads about which Davis and Day were complaining and felt it was "not a total misstatement of fact." 121 Sylvan Campf, a Portland 


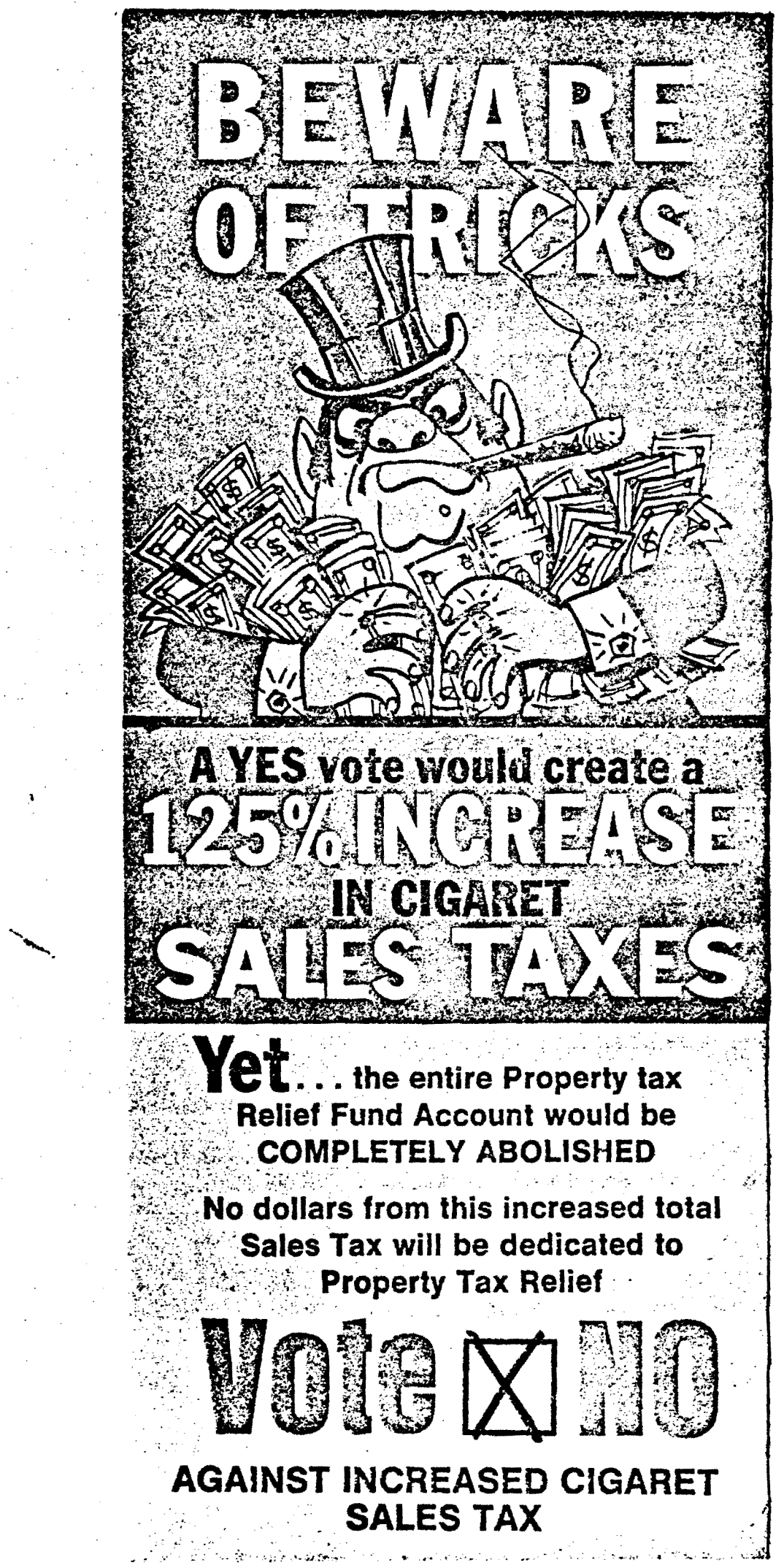

Figure 4. Anti-tax brochure; Oregonians Against any Sales Tax Committee, 1971-72. 
tobacco distributor who was among the leaders of the campaign to refer the tax hike to the voters, and one of the two men who were charged with corrupt practices violations in soliciting methods, said that the sponsors of the ad, "Oregonians Against Any Sales Tax Committee," were not misleading anybody. "I think it's the other way around." 122

On Thursday, January 6, upon the request of Secretary of State Clay Myers, a letter was written to Ron Collins, chairman of Oregonians Against Any Sales Tax, and Alan Campf, treasurer, warning them that the advertisements did make misrepresentations and were in violation of Oregon law. The attorney general said that if the ads were not withdrawn by 5:00 p.m. Thursday, his office would take action, perhaps by placing the matter before a state grand jury. Another letter went to Clyde Brummell, president of the homeowner's association, concerning statements made by his organization in the Voters' Pamphlet. The attorney general's letter stated that: "Both [two disputed television ads] contain statements. . that Ballot Measure 1. . would abolish the local Property Tax Relief Fund and that cigarette tax revenues are presently appropriated to that fund, rather than the State General Fund. It is [also] a misstatement of fact to say that Ballot Measure 1 abolishes the Property Tax Relief Account since that account had already been abolished and cigarette tax revenues are presently earmarked only for the State General Fund and the cities and the counties."

On Friday the television advertisements were cancelled. The advertising firm of Clenaghen and Associates, Inc., declared that the ads were "an honest mistake." Brummel wrote a lețter to Johnson, admitting some degree of error. "We regret our structure in the Voters' Pamphlet was in error as you see it. However, laymen do not structure sentences 
in the best of the King's English."

124

Also on Friday, those apologizing for error went on the offense. Having appeased the attorney general, the anti-cigarette tax people charged that the Voter's Pamphlet contained erroneous statements--this time, by the proponents. Maurice Sussman, attorney for the anti-tax committee, filed a letter with the secretary of state asking that he prosecute those responsible. He objected to statements in the Voters' Pamphlet because of the prediction about "possible" total cuts to only one or two state agencies, declaring that there is no evidence that can predict what the legislature might do in a special session. He also objected to the statement which said, "How about the state police. They'd be fair game. Eliminate them and you've found your $\$ 17.2$ million in one fell "selective cut"." 125 Sussman also objected to a statement that conveyed the idea that the tobacco companies would pay the tax. He said the tax is a consumer tax and would be paid by the purchaser of 126

cigarettes, not the manufacturer. Another objection the attorney had to the pro-tax pamphlet argument was the statement that the legislature would cut property tax relief if the ballot measure failed.

Saturday, January 8, the attorney general's office issued an informal opinion that statements made by the tax proponents were not in violation of Oregon law. George Bell, assistant to the secretary of state, said his office received an assistant attorney general's informal opinion that the Voters' Pamphlet statements in question were speculation and could not be regarded as facts. "While the author may have used "wild language," it does not constitute falsehood." .

Newspapers carried nothing more on the matter and it began to 
appear that the proliferation of corrupt practices violation charges had ended. Myers asked for apologies from persons who made false or misleading statements in the Voters. Pamphlet, statements he termed "extravagant and designed to frighten and intimidate the voters."

Monday, an apology was received in the secretary of state's office from William Gilbert, treasurer of the Citizens Against Raising Property Taxes Committee, the State Committee cover organization, in reference to a statement that all of the $\$ 17.2$ million deficit could be taken from the state police budget. He acknowledged in the letter that the General Fund doesn't contribute that much to the state police, so the deficit couldn't be met in that way, and informed the secretary of state that committee volunteers throughout the state had been instructed to stop distributing any information containing the error. 130

Then, on January 12, only six days before the election, Senator Cook brought a charge in another form, perhaps as a reaction to: Myers request for an apology. He accused Oregon's secretary of state and attorney general of "violent partisanship" in handling of cigarette tax measure matters, and demanded a special investigation to see whether there had been election law violations.

Since the referral by the people, both the secretary of state and the attorney general have worked hand in glove with supporters of the cigarette tax. I demand that the attorney general request either the Oregon State Bar or the chief justice of the Supreme Court to suggest to him an impartial lawyer to be appointed as a special assistant attorney general to investigate and bring charges for the violation of the Corrupt Practices Act during the course of this election.

Myers had replied to a public outcry over exaggerations in the state publication by saying that state law denied him authority to 
screen false or misleading statements. Cook challenged this. He said Myers had deleted, without consent, a reference in the Voters' Pamphlet material submitted by Haas and Cook, which described Cook as chairman of the Senate Tax Committee and Haas as the 1971 Democratic House 132

leader.

In the same release, Cook also charged McCall's staff and some appointees of violations of the Corrupt Practices Act: Tanzer, director of the Department of Human Resources, and L.B. Day, director of the Department of Environmental Quality. He accused them of soliciting funds in support of the five-cent increase, illegal under the Corrupt Practices Act permitting state employees to support partisan candidates and state political issues except during working hours.

On the same day Cook made the charges Day replied by saying that he had not violated the corrupt practices provision. At a news conference January 12, he handed out copies of a resolution adopted by the Environmental Quality Commission:

The Environmental Quality Commission, as part of its responsibility to the citizens of Oregon, hereby declares its unqualified support of both the cigarette tax and income tax programs adopted by the 1971 legislature and instructs the staff to disseminate full information to Oregon citizens on the effecf of $_{3}$ loss of revenues from these sources on Oregon environment.

Day cal led Cook's accusation "sheer nonsense. I'm doing exactly what the commission asked me to do." 134

On the same day Cook and Day were having their public debate, the governor made a last public plea for passage. At a special press conference January 12, McCall termed the tax boost the "most important tax 135 issue ever presented to the people."

At the same time the Oregon Journal criticized all parties in the 
dispute:

While there are reasoned arguments coming from both sides, the re is also this campaign of distortion and deceit, of trying to outscare each other.

How nice it would be if we could back up and start over, leaving out the terror tactics and just leveling with people honestly. Both sides can make strong cases without getting into the gutter.

houses. Ijs tempting to call for a plague on both their

A few closing shots were fired, but after the week-long series

of minor scrimages, it was all anti-climax. Brad Davis recapitulated

arguments used by the State Committee and then said:

Most of the money to finance the anticigaret tax program came from a Richmond, Virginia tobacco lobby. Do you really believe that a tobacco lobby from Virginia really gives a damn about your property tax relief, or your public schools, or mental institutions or any other program in Oregon for Oregonians: ${ }^{137}$

Last minute voter opinion surveys were conducted by newspaper columnists in Portland, Corvallis, Salem, Pendleton, and Bend, querying the man on the street and resulting in the usual balanced crosssection of opinion characterizing such surveys. The public relations firm employed by the State Committee, reported a pre-election survey showing 32 percent in favor; 31 percent against; and 37 percent unde138

cided. In an election even column, Doug Baker quoted a radio poll conducted by radio station KPOK, "nearly 2 to 1 against. . . ."

On January 18, 1972, Oregon voters passed the 1972 cigarette tax, Ballot Measure Number 1, by 245,717 to 236,937--roughly a 51 to 49 140

percent majority. Clay Myers had predicted slightly less than a 50 percent voter turnout- $-514,000$ ballots. On election day, 482,654 were 141

cast. The voters of Oregon had determined to accept the "band-aid"

tax. By a small majority, voters chose to believe it was necessary. 


\section{POST-ELECTION REACTIONS}

On the Sunday preceding the election, the Sunday Oregonian

"Forum" section carried an article with the following warning:

If Oregon history means anything " backers of the cigarette tax increase are facing heavy odds in trying to get it passed at a special election January 18 .

Oregon has had 10 special elections in its history and 12 measures referred by the voters, as was the cigarette tax increase, have been won over the years.

Only five of the 12 measures were approved by the people and four $3_{3}$ of them were in the first special election held in 1913.

While not altogether accurate in reporting Oregon's historic voting record, the writer was correct in one respect: the proponents did have sizable odds working against them.

But the voters said "yes" in the closest tax election in Oregon's history, a majority by only nine tenths of one percent. (Figure 5)

None of the advocates felt the public would vote against their own best interests. Tanzer believed that if the "facts" were made known, the voter would vote the "right way." 144 Governor McCall felt that the public's independence and clear-thinking would save what was 145

left of his budget. Al King said that "cigarettes are basically very unpopular, and even smokers didn't worry about the tax." ${ }^{146}$ KGW-TV

news analyst, Floyd McKay, felt the "opponents strained their credibil147

ity," and Jack Thompson, chief state elections officer and assistant secretary of state for more than ten years, said that "the people 148

could not be duped."

In Oregon, as in national and international politics, leadership opinions varied and those closest to the campaign expressed markedly different views about why the measure passed. Only the voters them- 


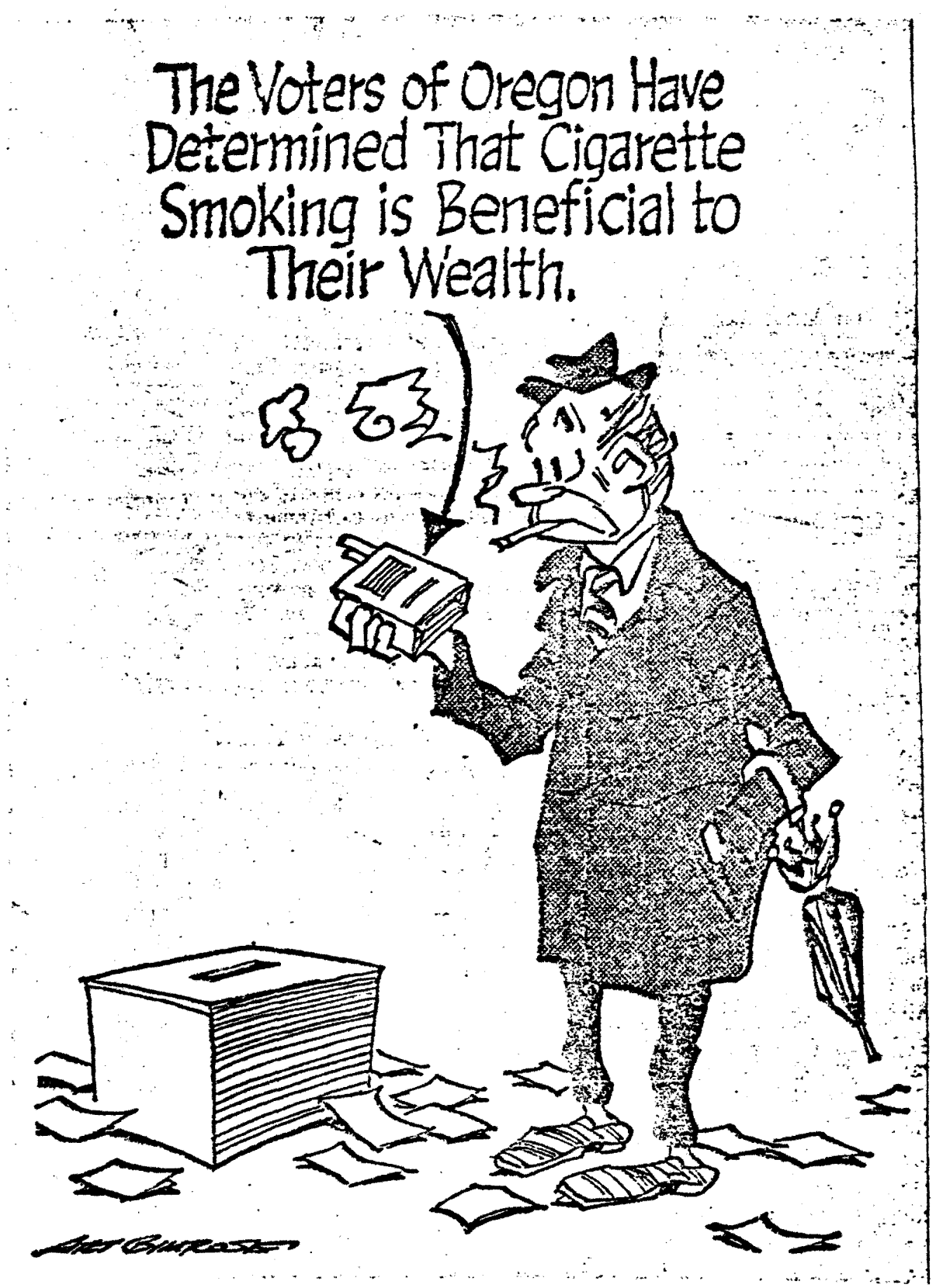

Figure 5. Editorial cartoon; Oregonian, January 20, 1972. 
selves, in the privacy of the polling booth, knew for certain why the

tiniest majority passed the cigarette tax increase.

Summary

The campaign had been waged on many fronts, appealing to special

groups as well as Oregonians in general. In summary, the proponents of

the tax increase said:

1. The state government is in a fiscal jam. It needs the money the tax hike would raise to pay the bill for services rendered the public.

2. An expanded property tax relief program aiding persons on low incomes will suffer if the tax hike is turned down.

3. Oregon's present cigarette tax (four cents a pack) is fourth from the bottom among the 50 states. Even with the increase Oregon can still expect to sell cigarettes to Californians who pay a 10-cents-a-pack tax and particularly to Washingtonians who pay a 16 cents tax.

4. While alternatives to the cigarette $\operatorname{tax}$ can be found, getting the legislature and the voters to approve another type of tax increase during the current fiscal period are minimal at best.

The opponents argued:

1. A cigarette tax per se is bad. It is a sales tax and hits the poor man hardest. It is not based on the ability to pay principle.

2. If the voters okay the tax hike they may be actually delaying a meaningful overhaul of Oregon's tax structure based on ability to pay.

3. State government wan't collapse if the tax hike is vetoed. It can survive the estimated $\$ 17.5$ million drop in revenue if the voters turn down the tax.

There is, of course, no way to know for certain how many people were influenced by the issues, and the structure of the arguments. The previous commentary demonstrates how muddy the issues became as the campaign progressed. 
We do know, however, that nearly every available channel was used in an effort to influence the voter. Specialized campaign Iiterature was directed to group members in the form of memos, fact sheets, letters, and organizational publications. Personal appearances by an extensive army of speakers further disseminated the message to specific audiences with similiar interests. The electronic media was utilized to channel messages to more generalized audiences using television advertising, public debates, editorial commentaries. Radio advertisements, talk shows and news broadcasts reached a smaller audi= ence--one confined to only the Portland metropolitan area.

Newspaper reporters picked up information from press releases and public statements and relayed that information to a wider audience across the state. Editorial writers and feature columnists commented extensively on both the substantive issues and the campaign methods employed by the cover committees on both sides.

Campaign strategy did not attempt to change attitudes toward taxation. The media campaign did not dwell on the functioning of state government or the dollars needed for general governmental needs per se; not did the speeches made by state officials, legislators, and special interest group representatives. Instead, the appeals attempted to reinforce existing positive attitudes toward: (1). job security (in the case of specialized appeals to state employees), (2) aid to the handicapped and emotionally disturbed (appeals through radio and television advertising as well as fact sheets and public speeches), (3) preservation of Oregon's quality of life (chiefly through appeals by L.B. Day calling attention to envi ronmental needs), and (4) self-interest of homeowners (the issue of property tax relief). 
According to researchers in persuasion effects, long term attitudes and voter predispositions toward issues cannot be changed to 149 any measurable degree by a short term campaign. But persuasion can affect short term perceptual change by creating a linkage between past positively valued attitudes and neutral or inactive attitudes. The campaign strategy used this theory in planning the content of persuasive messages. Ecology, property tax relief and job security were connected to an extension of a tax already approved by the electorate. ${ }^{150}$ voters were asked to vote, not on a tax increase, but for their own special interests.

Underlying the substantive reality of Oregon's fiscal dilemma, were the innuendos, threats, and charges of ethical and legal violations made by opposing sides. Publicity that was obtained by the charges drew attention to the issues even if they did not clarify them. And the $\therefore$ charges were merely an outgrowth of the fear appeals themselves.

A seasoned veteran of political campaigning, Herbert Baus, of the California public relations firm of Baus and Ross, says that it is the task of a successful campaign to "tastefully frighten voters into believing that failure of the issue would be disasterous. . . ." Although to differing degrees, both the supporters and the opponents must have believed this. The state committees on both sides couched their campaign rhetoric in fear provoking language. Even the directed appeals of interest groups focused on loss of jobs or programs.

Chapter V. considers the effect on the voters of campaign strat: tegies in the 1971-72 referendum campaign, asking whether or not they believed arguments presented in support of the cigarette tax increase. 


\section{Notes}

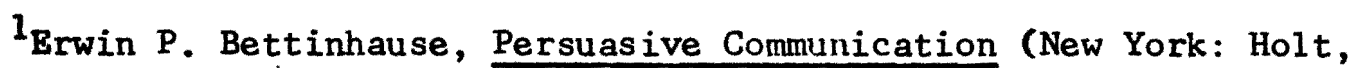
Rinehart and Winston, Inc, 1968), P. 265.

2L.B. Day, Director of Department of Environmental Quality, interview by phone, July 25, 1972 .

\section{Ibid.}

\section{${ }^{4}$ Diel, interview.}

5 Referring to a plan proposed by the Oregon-Washington Coalition for Clean Air--1971; Day, interview.

"Oregon Official Hits Anti-tax Ads," Register-Guard (Eugene, Oregon), January 4, 1972.

${ }^{7}$ Robert Davis, interview.

${ }^{8}$ Tanzer, interview.

${ }^{9}$ From a press release, December 13, 1971, prepared from remarks to Washington County Public Affairs Forum, Beaverton, Oregon, December 13,1971 .

${ }^{10}$ Tanzer, interview.

${ }^{11}$ Ibid.

${ }^{12} \mathrm{Clarence}$ Jones, Director, Oregon Economic Opportunity Division, Department of Human Resources, Salem, Oregon, personal interview in Salem, Oregon, April, 1972.

13 F1iers were those developed by the C.A.A., not the State Committee.

${ }^{14}$ Jones, interview.

15Marion Hughes, Department of Human Resources, correspondence received July 18,1972 . 1972.

16"Cigarette Tax Backed by Nilsen," Oregon Journal, January 7,

17"Young Addresses Chamber of Commerce: Supports Cig Tax," Democrat Herald (Baker, Oregon), December 17, 1971. 

1971.

18."Educator Urges Cig Tax Hike," Oregon Journal, December 18,

${ }^{19}$ Robert Davis, interview.

${ }^{20}$ Bettinghause, p. 265 .

${ }^{21}$ C.R. Hoyt, Letter to the Editor, "Paper Committee," Oregonian, January 13,1972 . 1972 .

${ }^{22}$ Senator Jason Boe, Reedsport, correspondence received June 24,

23."Smokes Tax Need Pushed by Backers," Oregonian, December 20, 1971.

24"Senator Boe Says Cig Tax Vital," Siuslaw News (Florence, Oregon), January 6, 1972 .

${ }^{25}$ Subsection 1, Section 7, Chapter 2, "Oregon Laws 1971 Special Session," provides that a nonpartisan explanation be written for each measure appearing on the ballot and included in the Voters' Pamphlet.

${ }^{26}$ Voters Pamphlet: January 18,1972 , pp. 4-5.

27"Heard Tells Soroptimists: Cigarette Tax Defeat Would Mean 2nd Meet," Herald and News (Klamath Falls, Oregon), January 7, 1972.

${ }^{28}$ Roberts, interview.

${ }^{29}$ Fadley, correspondence.

30 "Four Debate Cigarette Tax Hike," Register-Guard, January 8, 1972.

${ }^{31}$ Representative Jack Ripper, Coos Bay, correspondence received July 14, 1972.

32"The Big Guns are Loosed," Lake County Examiner (Lakeview, Oregon), December 16, 1971.

33"Vote Yes," Umatilla Sun (Umatilla, Oregon), December 23, 1971.

34"Atiyeh Puts OK on Cig Tax Effort," Daily Courier (Grants Pass, Oregon), January 4, 1972. 
35"OSU Still Could Gain Burner Research $\$ \$ \$, "$ Democrat-Herald, December 27, 1971. 1972.

36."Cigarette Tax Claims Distorted, Says Gwinn," Ibid., January 5,

37"Cig Tax Discussion on Tap Wedne sday," Ibid., January 11, 1972.

${ }^{38}$ The North Coast Eagle-Times reported that a rumor was circulating around the capital that the governor might run for national office in the general election as an Independent: "Parties, Primaries, Polling Places, and People," North Coast Eagle-Times (Wheeler, Oregon), January 6,1972 .

${ }^{39}$ Robert Davis, interview.

40"McCall Seeks Support for two Ballot Measures," Bast Oregonian (Pendleton, Oregon), January 11, 1972.

41"McCal1 Says Chances Are he Won't Seek Senate Seat," Ibid.

42."A Huff and a Puff May blow the Tax on all Cigarettes," Capital Journal, January 15, 1972.

${ }^{43}$ According to Brad Davis, Governor Tom McCall may have spoken to editor Eric Allen of the Medford Mail Tribune, a 1 arge southern Oregon paper which had editorially opposed the cigarette tax increase on the basis of "regressive taxation." Subsequent editorials clearly suggest that Allen attempted to give both sides equal representation: he refined his position but did not modify it. The Mail Tribune is one of the few moderate-liberal Democratic dailies in the state.

44.Thompson, interview.

${ }^{45}$ Enright, interview.

${ }^{46}$ Ibid.

${ }^{47}$ Ibid.

${ }^{48}$ Ibid.

${ }^{49}$ Ibid.

${ }^{50}$ Oregon State Employees Association News, Special Section, (Salem, Oregon), January, 1972 . 
51 Myron. Cropsey, Past President Corvall is Chapter No 72, Oregon State Employees Association, correspondence dated July 11, 1972.

52 Over 200 school budget elections have been defeated each year since 1967, according to Patrick Meany, Assistant Executive Secretary, OBA, interview by phone, July 25, 1972 .

${ }^{53}$ A study on public attitudes toward taxation conducted in 1972 revealed that 45 percent of the total U.S. public said local property taxes were the "least fair tax": "Public Opinion and Taxes," Advisory Commission on Intergovernmental Relations (Washington, D.C., May, 1972), p. 2 .

${ }^{54}$ Daniel son, interview.

55 Ibid.

56"Smoking Law Change Urged by Principals," Register-Guard, January, 9, 1972 .

57 Thomas Scanlon, Public Information Officer of AFL-CIO, Salem, Oregon, correspondence dated June 18, 1972.

${ }^{58}$ Rigby, correspondence.

59"Educators Unit Urges Smokes Tax," Daily Astorian (Astoria, Oregon), January 12, 1972.

"60 "Enterprise Bonds Won't Be Sold," LaGrande Observer (LaGrande, Oregon), January 11, 1972; "Cig Tax Hike Defeat would cost Hilhi $\$ 31,000, "$ Argus (Hillsboro, Oregon), January 10, 1972. .

${ }^{61}$ Donald L. Jones, Executive Secretary, League of Oregon Cities, Salem, Oregon, correspondence dated July 19, 1972.

${ }^{62}$ P. Jerry Orrich, Bxecutive Secretary, Association of Oregon Counties, Salem, Oregon, correspondence dated July 18, 1972.

${ }^{63} \mathrm{John}$ Hawkinson, President, Clackamus Community College, Oregon City, Oregon, interview by phone, July 19, 1972.

${ }^{64}$ Post, interview.

65."Cigarette Vote Costs Told," Oregon Journal, January 14, 1972. 
66 Nimmo, p. 123

67 Bditorial, "We Recommend No," Herald and News, January 16, 1972.

68 "Chamber Backs Cigarette Tax," Ibid., January 11, 1972.

${ }^{69}$ See for instance: "Chamber Favors Tax," Oregon Journal, January 12, 1972; "Chamber Board Backs Cigarette Tax Increase," Argus, January 6, 1972; "Best of Available Alternatives Says Eugene Chamber," Capital Journal, December 21, 1971.

70"McCrae Taiks on Vote: "band-aid" for Schools," Spokesman (Pendleton, Oregon), January 18, 1972.

71"Yes for Tax Relief," Oregonian, January 17, 1972.

72"Packwood All ays Sisters Mine Fear," Ibid., January 14, 1972.

73"Senior Citizens Get Holdridge Report," Rainier Review (Rainier, Oregon), December 23, 1971. 1972.

74"Cigarette Tax Vote on Tuesday," Register-Guard, January 16,

75."Tax Hike Backed by Home Builders," Mail Tribune (Medford, Oregon), January 16, 1972 .

76"Cigarette Tax May Bring $\$ 400$ to Some Owners," Greater Oregon (Albany, Oregon), January 14, 1972.

${ }^{77}$ Conservative by this writer's judgment on the basis of editorial comment 1 abeling former Senator Wayne Morse, George McGovern and Arthur Schlesinger "Puling pacifists and anti-American, who are anxious to help the communists take over," A.M. Tewksbury, Oregon Voter Digest (Portland, Oregon), June 1, 1972.

\section{${ }^{78}$ Ibid., p. 32.}

${ }^{79}$ Editorial, "Cigarette Tax Hike Looks Like Blackmail," Daily Tidings (Ashl and, Oregon, January 13, 1972; Editorial, "We Recommend "NO"," Herald and News, January 16, 1972; Editorial, "An Unpleasant Decision for Jan. 18," Mail Tribune, January 10, 1972; other Oregon newspapers came out opposed, but they were chiefly small weeklies: see for example, Editorial, "Tax Discriminatory," Central Oregonian (Prineville, Oregon), December 23, 1972. 
${ }^{80}$ Baus and Ross, P. 360.

${ }^{81}$ The informant prefers to remain unnamed.

82,"Smokes Tax Need Pushed by Backers," Oregonian, December 18, 1972 .

83. Lesh, interview.

${ }^{84} \mathrm{King}$, interview.

85 Lesh, interview.

86 With the exception of a few large contributions to the campaign, notably, Crown Zellerbach, Weyerhauser, Georgia Pacific, and Equitable Savings and Loan: "Statements in Support of Ballot Measure 1 ," January 18, 1972 Special Election.

${ }^{87}$ Press release, Oregon State Council for Senior Citizens, Jack Nelson, president, November 10, 1971, obtained from Alton King.

${ }^{88}$ King, interview.

${ }^{89}$ Copy of correspondence from Nelson to King, dated November 22, 1971, obtained from King.

${ }^{90}$ Jack Nelson, Salem, Oregon, correspondence dated August 7, 1972.

${ }^{91}$ Press release, Celeste Campbell Center, issued by Mrs. Ruth Snyder, kicking off the Lane County Coalition of Seniors and Young Voters, December 15, 1971, obtained from Alton King.

${ }^{92}$ Ruth Shephard, Eugene, Oregon, interview by phone, July 17, 1972.

${ }^{93} \mathrm{King}$, interview.

94 Ibid.

95"SOC Sends Delegates to IUSOSSHE Meet," Siskiyou (Southern Oregon College, Ashland, Oregon), January 14, 1972.

${ }^{96}$ King, interview.

97 Ibid. 
${ }^{98}$ It will be remembered that this was the first Oregon election since ratification of the U.S. Constitutional Amendment permitting 18 year old vote.

${ }^{99}$ Ron Wilkinson, 1971-72 Student Body President, Oregon State University, Corvallis, Oregon, correspondence dated July 8, 1972.

100, BMCC Student Council Backs Cigarette Tax," East Oregonian, January 13, 1972 . $18,1972$.

101"Cigarette Tax Boost Goes to Polls Today," Spokesman, January ${ }^{102}$ King, interview.

${ }^{103}$ Editorial, "Young and 01d," Register-Guard, January 21, 1972.

${ }^{104}$ Shephard, interview.

105 "Legislators Form Committee," Oregonian, December, 29, 1971 ;.

Cook was recommending payment in advance by corporations and those selfemployed similiar to those provisions in the federal law.

106"Legislators Oppose Tax," Oregon Journal, December 28, 1971.

107."Willits Says No," Ibid.

108, Bazett Addresses Civic Group," Daily Courier, January 3, 1972.

${ }^{109}$ Editorial, Gazette-Times, December 22, 1971.

${ }^{110}$ Ibid.

111"Raft of Opposition to Tax," The World (Coos Bay, Oregon), December 27, 1971 .

112 Voters' Pamphlet, pp. 11-12.

${ }^{113}$ Campbe11, interview.

114"Contributions Made Known," Oregonian; January 11, 1972; Campbel1, interview. 
115 Definition of propaganda used here: "Propaganda can be thought of as deliberatel y evoked and guided campaign to induce people to accept a given view, sentiment or value. Its peculiarity is that in seeking to attain this end it does not give fair consideration to opposing views. The end is dominant and the means are subservient to this end. Hence, we find that a primary objective. . . is the effort to gain the acceptance of a view not on the basis of the merits of that view but, instead, by appealing to other motives": Herbert Blumer, "The Crowd, the Publ ic, and the Mass," The Process and Effects of Mass Communication, Wilbur Schramm, ed. (Urbana: University of Illinois Press, 1971), PP. 374-375.

${ }^{116}$ It will be remembered that action by the 1971 legislature changed the allocation of property tax relief. Including the additional five cents in the current bill, home owners would. receive relief proportionate to their share of the total amount. If the tax were defeated, homeowners as well as state agencies would feel the two percent cuts.

${ }^{117}$ Advertisement, Oregonian, January 11, 1972.

118"Day Responds to Anti's Ads," Register-Guard, January 4, 1972.

119 "War of Words Over Cigaret Tax Vote Heats Up," Oregon Journal, January 5, 1972 .

${ }^{120}$ Davis, interview. 1972 .

121"Anti-Smokes Tax TV Ads Criticized," Daily Astorian, January 5,

122 Ibid.

123 "Cigarette Tax Foes Warned to Keep their Facts Straight," Oregonian, January 7, 1972.

124"Cig Tax Hike Foes Hit Voters' Pamphlet Ad," Oregon Journal, January 7, 1972 .

${ }^{125}$ Only $\$ 2.6$ million of the $\$ 25.6$ million state police budget comes from the General Fund. Only contributions from the state would be subject to the two percent cuts: Oregon Tax Research, p. 3 .

126"Cig Tax Hike Foes Hit Voters" Pamphlet Ad," Ibid.

127"Cig Tax Groups Statement Held no Violation," Ibid., January 8 , 1972 . 
Ibid.

129"Myers Requests Apologies for Tax Vote Misstatements," Oregonian, January 11, 1972 .

130 Ibid.

131 "Senator Cook Claims Aides "Partisan" in Cigarette Tax Matters", Oregon Journal, January 12, 1972.

${ }^{132}$ Both were accurate statements: see Directory Fifty Sixth Legislative Assembly: 1971-72 (OEA Government Relations Department, Tigard, Oregon, 1971), pp. 2-3.

13, 1972 .

133"Environment Chief Denies Violation," Daily Courier, January

\section{${ }^{134}$ Ibid.}

135."McCal1 Makes Plea for Cig Tax," Oregon Journal, January 13, 1972; "McCall Urges Cigarette Tax Hike," Oregonian, January 13, 1972.

136 Editorial, "Campaign Strategy: Scare 'Em," Oregon Journal, January 11, 1972 .

137"Cig Tax Backers Make Final Passage Appeal," Oregon Journal, January 17,1972 .

${ }^{138}$ Kennedy, interview.

139 "Doug Baker--The Heave--Ho At Levitz," Oregon Journal, January 17, 1972 .

140"Official Vote Abstract: 1972 Special Election."

141"Cigaret Tax Vote Light," Oregon Journal, January 18, 1972.

142"Official Vote Abstract."

143" "NO Balloting Very strong in Past Elections," Oregonian, January, 16,1972 .

144 Tanzer, interview.

${ }^{145}$ Robert Davis, interview. 
$146_{\mathrm{King}}$, interview.

147 Floyd McKay, KGW-TV News Analyst, correspondence dated July 6,1972 .

148 Thompson, interview.

149 See for instance: Thonas W. Benham, "Polling for a Presidential Candidate: Some Observations on the 1964 Campaign," Public Opinion Quarterly, XXIX (Summer, 1965), p. 196; Shirley Star and Helen MacGil Hughes, "Report on an Educational Campaign: The Cincinnati Plan for the United Nations," American Journal of Sociology, Vol 55 (1950), pp. 389400; El ihu Katz, "The Two-Step Flow of Communication: An Up-To-Date Report of an Hypothesis," Public Opinion Quarterly, Vol. 21 (Spring, 1957), pp. 61-78.

${ }^{150}$ The Beal and Bolen Model of Social-Action describes successful campaigns for community change by saying that the persuader should "sell the people that new change is merely an extension of an old policy," in Bettinhause, p. 267.

$151_{\text {Baus and Ross, p. } 49 .}$ 


\section{CHAPTER V}

\section{THE SURVEY}

Large national campaign management firms recognize that a popular referendum differs considerably from the election of a candidate because there is no major personality demanding voter attention. Instead the election "involves complex debates about . . technicalities 1

of funding." The principal problem in a referendum or initiative campaign then, is to convince the public that passage of the ballot measure would be of public benefit; and motivate them to travel to the polls to cast a favorable ballot.

Taken together, the facts of Oregon's fiscal situation, the activities of interest groups on both sides of the question, and traditional Oregon voter behavior on tax measures, suggest that a great many variables were at work on the vote outcome. Without a comprehensive survey of the entire state we cannot state with certainty that the measure passed because of, or in spite of, the formal campaign However an analysis of voter opinions taken from two highly divergent counties may provide evidence supporting the thesis hypothesis. That is, that the united efforts of special interest groups was the deciding factor in the narrow margin of victory.

The voter survey, reported in this chapter, was an effort to answer three major que stions: (1) Who voted in this election? (2) How did they vote? and (3) Why did they cast their ballots as they did? The poll attempted to discover which issues were most important to the voters, - 
how they obtained their information on the tax, which influence source was primary in their vote decision, and how they viewed the activity of interest groups in the campaign.

The leadership survey attempted to find out what influentials thought were the reactions of the voters. The questions paralleled the voter questionnaire.

\section{BENTON AND DOUGLAS COUNTIES}

Benton and Douglas counties are dissimilar by practically every measure. Benton is smaller geographically, has a smaller population $(53,776$ to Douglas at 71,743$)$, and fewer registered voters. Yet approximately the same number of persons in each county voted in the January special election ( 56 percent of the total registered voters in Benton; 49 percent in Douglas). It may be that the campaign generated more interest in Benton, but it may also be that a comparatively higher socioeconomic level provides for a generally higher vote turnout in special elections.

The 1970 census figures show that the median grade of school completed by residents of Douglas county is 11.8 , while in Benton the median grade completed is 12.9 . Educational level and income are generally recognized to be directly related, and so they are in the sample counties. Benton's mean family income is $\$ 11,412$; while Douglas is lower at $\$ 9,470$. Nearly twice as many persons in Benton are employed in the professional or technical fields. Douglas has a larger proportion of residents employed as 1 aborers. 3

The higher education and per capita income in Benton is a reflection of the chief employment industry. Oregon State University is now sit- 
uated in Corvallis, the county seat (population 24,795 ). The heaviest concentration of Benton's population resides in or around the college town and Corvallis businesses depend heavily on income from the OSU academic complex.

Douglas, on the other hand, is chiefly a logging, mining and fishing area extending from the coast town of Reedsport, to the Cascade Mountains. Many small towns within Douglas county boundaries have populations of less than 1,000 . The largest city is Roseburg, the county seat (population 13,902 ). No large state facilities are located in Douglas, and the only institution of higher education is Umpqua (enrollment, 1,507$)^{5}$

Benton county receives a significantly larger volume of electronic media information through Portland stations. The actual market share that Portland stations receive in Benton is 57 percent of total television households $(13,400 \mathrm{~T} . \mathrm{V}$. households). Douglas receives only limited Portl and television, five percent of the total possible market share, through a franchised cable firm (21,700 T.V. households); and has practically no radio reception.

Benton is also more affected by newspapers than is Douglas . Fortypercent of households receive either the Portland Oregonian or Journal, as opposed to only 21 percent in Douglas.

In sum, both geographically and culturally, Douglas county is more isolated from the influence of large inetropolitan newspapers, and 8 television and radio stations.

In Benton county the cigarette tax measure was approved by over 9 2,000 votes; Douglas defeated it by the same margin. 
II. THE VOTER SURVEY

\section{Survey Procedure}

In Chapter I, the survey methodology was described as having been composed of a random sample selected from a population of individuals who had actually cast their ballots in the January 18, 1972 Special Election. Approximately 250 questionnaires were mailed to voters through the random procedure. Of total questionnaires mailed, 28 percent were returned (Benton, 71; Douglas, 69).

\section{Validation of Survey Sample}

A comparison of the sample to the population in each county demonstrates that the response is representative by two measures: party registration, i.e., number of Democrat and Republican ballots issued by election officials; and total "yes" and "no" votes cast. The number of Democrats and Republicans issued ballots in each county was obtained from the "Official Voter Abstract of the 1972 Special Election," as was the vote tally. Based on these figures, the number of expected returns in each category was computed using a $\not$ test for a binomial experiment $\left(Z=\frac{Y-n p}{\sqrt{n p q}}\right)$.

This procedure demonstrates that the party preference and the "yes-no" distribution of those responding in the sample population was not significantly different (at the 10 percent level) than the entire population (Table III):

It would have been desirable to compare other factors such as the percentage of those 18 to 21 years old casting their vote and the percentage of this age group who responded to the questionnaire. Since 
TABLE III

VALIDATION SCORES BASED ON ACTUAL BALLOTS ISSUED AND QUESTIONNAIRES RETURNED

\begin{tabular}{|c|c|c|c|c|c|c|}
\hline \multirow[b]{2}{*}{. } & \multicolumn{2}{|c|}{$\begin{array}{l}\text { FRACTION OF } \\
\text { VOTES CAST } \\
\text { \# Expected(a) }\end{array}$} & \multicolumn{2}{|c|}{ SAMPLE } & \multicolumn{2}{|c|}{ DIFFERENCE } \\
\hline & $\begin{array}{c}\text { B Cnty } \\
\#\end{array}$ & $\begin{array}{c}\text { D Cnty } \\
\#\end{array}$ & $\begin{array}{c}\text { B Cnty } \\
\#\end{array}$ & $\begin{array}{c}\text { D Cnty } \\
\#\end{array}$ & $\begin{array}{c}\text { B Cnty } \\
\%\end{array}$ & $\begin{array}{c}\text { D Cnty } \\
\%\end{array}$ \\
\hline Democrat & 29.67 & 36.39 & 23. & 34. & -1.62 & $-.59 \star$ \\
\hline Republ ican & 35.08 & 28.66 & 38. & 29. & .70 & $.08^{*}$ \\
\hline Yes vote & 49.75 & 26.90 & 49 & 32. & -.19 & $1.26^{\star}$ \\
\hline
\end{tabular}

*No significant difference at the $10 \%$ level.

(a) Fraction of number returnes expected in each category based on actual votes cast. 
the re is no way to discover such variables as age, sex, income and education within the limitations of the survey design, there is no apparent way to validate the resulting data further. However, based on the above measures of variability, the survey is judged to be a valid representation of the voter population in each of the two Oregon counties.

\section{SURVEY FINDINGS}

\section{The Voters}

With respect to demographic factors, it appears that the largest voter turnout in both counties was among persons between the ages of 30 to 60 ; those who reside in urban areas; and persons employed in white collar occupations. It would al so seem that a definite majority of those who voted in the 1972 special election also vote in every, or almost every election (Benton, 97 percent; Douglas 98 percent).

A large number of females, persons over sixty and housewives voted. There is no way to determine whether the high percentage is bias due to the fact that certain groups are predisposed to return mail questionnaires, or whether a proportionately larger number of females, hou sewives and persons over sixty actually voted in this election. Results of other voter surveys conducted on a national level in presidential elections, demonstrate that a slightly larger percentage of women than men do in fact vote; and more persons over 45.

In Benton, more Republ icans voted than did Democrats ( 54 percent); In Douglas slightly more Democrats ( 49 percent). This data reflects the party registration in each county. (Table IV) 
TABLE IV

POPULATION DISTRIBUTION IN SAMPLE

\section{Benton Douglas}

$\begin{array}{lrrrr}\text { Age } & \underline{\mathbf{N}} & \underline{\%} & \underline{\mathbf{N}} & \underline{\%} \\ 18-21 & 3 & 4 & 1 & 1 \\ 22-29 & 9 & 13 & 9 & 13 \\ 30-39 & 20 & 28 & 10 & 14 \\ 40-49 & 15 & 21 & 17 & 25 \\ 50-59 & 12 & 17 & 13 & 19 \\ 60- & 11 & 15 & 16 & 23 \\ & \overline{70} & \overline{98} & \overline{66} & \overline{95}\end{array}$

$\underline{\text { Sex }}$

Male

Female

$\begin{array}{llll}24 & 34 & 26 & 38 \\ \frac{46}{70} & \frac{65}{99} & \frac{40}{66} & \frac{58}{96}\end{array}$

Residence

City

Suburb

Rural

\section{Bducation}

Benton Douglas

Union Membership N $\% \quad \underline{N}$

Member $\quad 20 \quad 28 \quad 21 \quad 30$

Non-member

$\begin{array}{llll}\frac{50}{70} & \frac{70}{98} & \frac{46}{67} & \frac{67}{97}\end{array}$

Occupation

$\begin{array}{lrrrr}\text { Farm Operator } & 0 & 0 & 2 & 3 \\ \text { Housewife } & 28 & 39 & 20 & 29 \\ \text { Profes-Tchncl } & 22 & 31 & 23 & 33 \\ \text { Bss-Mngrl } & 7 & 10 & 8 & 12 \\ \text { Retired } & 7 & 10 & 7 & 10 \\ \text { Unemployed } & 1 & 1 & 0 & 0 \\ \text { Clerk-sales } & \frac{1}{66} & \frac{1}{92} & \frac{2}{62} & \frac{3}{90}\end{array}$

Income

Under $\$ 5,000 \quad 17 \quad 23 \quad 9 \quad 13$

$\begin{array}{lllll}\$ 5,000-9,999 & 12 & 17 & 21 & 30\end{array}$

$\$ 10,000-14,999 \quad 21 \quad 30 \quad 21 \quad 30$

$\begin{array}{lllll}\$ 15,000-25,000 & 15 & 21 & 13 & 19\end{array}$

$\begin{array}{lllll}\$ 26,000 & \text { plus } \quad \frac{3}{68} & \frac{4}{96} & \frac{2}{66} & \frac{3}{95}\end{array}$

Total Returns $\quad 71$

69

$\begin{array}{lrrrr}\text { Sm H.S. } & 4 & 6 & 5 & 7 \\ \text { H.S. } & 17 & 24 & 23 & 33 \\ \text { Sm Clg } & 17 & 24 & 18 & 26 \\ \text { Clg } & 13 & 18 & 11 & 16 \\ \text { Post Clg } & \frac{18}{69} & \frac{25}{98} & \frac{6}{63} & \frac{9}{91}\end{array}$

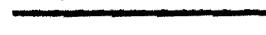




\section{Population Group Vote}

According to the survey findings, over 50 percent of all age grcups voted "yes" in Benton county. In Douglas county only those under 29 years of age and between, 50 and 59 voted in favor of the cigarette tax increase. The largest "no" vote appeared to be in th 30 to 39 age group in both counties.

Unfortunately the sample of persons affiliated with a professional association or union was small, and for other reasons not useful in ascribing group affiliations to voting behaviors. Also, most of those answering "yes" to the question of union membership, were members of organizations inactive in this campaign. Therefore, certain questions posed in the introduction must remain unanswered: (1) "Did membership in a particular group make it more probable that persuasive communication regarding the issues emanating from their group would be received favorably?" and (2) "To what extent did they look to that group for verification of an election choice?"

In regard to other population groupings there is a substantial representation in the sample. In Benton county 71 percent of males surveyed voted "yes," and 63 percent of females; in Douglas county an equal proportion of men voted for and against the measure (50 percent), while more females voted "no" ( 53 percent).

More people living in open country from both counties voted "no." In Benton those who lived in suburbs or cities voted "yes," more, whereas in Dougl as the "yes-no" vote was divided between rural and urban residents with slightly more voting "no" who lived in cities or suburbs.

Based on level of education, the only group in Benton with fewer than 50 percent voting "no" were those with less than a high school 
degree. In Douglas county, the only groups tallying a higher percentage of "yes" votes, were those with college or post-college educations, suggesting that in this election at least, the more highly educated voter favored the tax.

Occupational groups with the largest number of responses to the survey--housewives--voted 71 percent "yes" in Benton, while in Dougl as only 40 percent voted in favor. The only occupational group registering over 50 percent "yes" votes in Dougl as were those employed in professional technical fields.

In answer to the question of what is the relationship between population groups and the "yes-no" vote, we can say that in both counties it was the urban voter with a moderate to high income, a college education and a white collar job who supported the cigarette tax. While a high percentage of women in Benton voted "yes"--in both counties more men favored the tax (Appendix F).

Attention to Political Messages

Respondents were asked how often they listen to political messages through (1) attendance at public meetings or debates, (2) attention to political advertising over radio or television, and (3) conversations with friends or relatives (Table $\nabla$ ).

Few from either county said they attended meetings or political rallies on a regul ar or frequent basis. They survey found that among Benton voters, 62 percent rarely attend and 24 percent never attend such meetings; 57 percent of Dougl as county respondents said they rarely attend, and 36 percent said they never did. Those who said they did attend meetings frequently (eight percent in Benton; three per- 
TABLE V

TOTAL RESPONSES TO QUESTION RELATING TO GENERAL ATTENTION TO ROLITICAL MESSAGES FROM BOTH COUNTIES

\begin{tabular}{rlll}
\multicolumn{2}{c}{ Benton } & \multicolumn{2}{c}{ Dougl as } \\
N : & PCNT & PCNT \\
\hline
\end{tabular}

I. POLITICAL MEETINGS

$\begin{array}{lrcrc}\text { Regularly } & 0 & 0 \% & 1 & 1 \% \\ \text { Frequent1y } & 6 & 8 & 2 & 3 \\ \text { Rarely } & 44 & 62 & 39 & 57 \\ \text { Never } & 17 & 24 & 25 & 36 \\ \text { No response } & 4 & 6 & 2 & 3 \\ \quad & & - & 69 & 100 \%\end{array}$

II. POLITICAL ADVERTISING

$\begin{array}{lrcrc}\text { Regularly } & 17 & 24 \% & 13 & 19 \% \\ \text { Frequently } & 31 & 44 & 39 & 57 \\ \text { Rarely } & 20 & 28 & 14 & 20 \\ \text { Never } & 1 & 1 & 1 & 1 \\ \text { No response } & 2 & 3 & \underline{3} & -3 \\ \quad & & & & \\ \quad \text { Total } & 71 & 100 \% & 69 & 100 \%\end{array}$

III. CONVERSATIONS ABOUT POLITICS

\begin{tabular}{lrcrc} 
Regularly & 36 & $51 \%$ & 31 & $45 \%$ \\
Frequent1y & 31 & 44 & 28 & 41 \\
Rarely & 3 & 4 & 6 & 9 \\
Never & 0 & 0 & 2 & 3 \\
No Response & 1 & 1 & 2 & 2 \\
\multicolumn{1}{r}{ Total } & 71 & $100 \%$ & 69 & $100 \%$
\end{tabular}


cent in Douglas) are persons between the ages of 30 to 39 , with high school or some college. But again the sample is too small to form any conclusions relating age or education to attendance at political meetings .

Most people apparently receive the largest proportion of their political information either from conversations with friends or by listening to political advertising over radio or television. In Benton, 44 percent named frequent attention to electronic media sources; 57 percent in Douglas. The highest percentage in both counties said they either always or on a frequent basis talk with friends about politics (51 percent always, 44 percent frequently in Benton; 45 percent always, 41 percent frequently in Douglas). These are people between the ages of 30 to 49 , of both sexes, and with at least some college education.

Those who listen to political advertising most have high school or some college education and fall into every age group, with slightly more in the age bracket of 30 to 49 . These voters are equally represented by both sexes. The only population groups in Benton with a notable number of responses indicating rare attention to political advertising were those between the ages of 30 to 39 , with college or post college educations. This group named personal conversations on political matters as a regular occurrance.

We can reason from the survey findings that persons with high interest in politics among the better educated engage in a proportionately higher percentage of their time talking politics with friends. Those with less than college educations also have a high incidence of political conversations with friends, but also attend to electronic media advertising with more frequency. It is not surprising that persons in 
the age range of 30 to 49 engage in more active political attention. These are the child rearing, working years, when expenses are highest and income is reaching its peak. Hence these people can be expected to be more alert to changes in public policy that may have an affect on them.

Reasons for the Vote

Fiscal Impact. The question was asked: "Would you have been affected if the cigarette tax measure had failed?" The purpose of the question was to discover if a high proportion of voters cast their votes because of a belief that they would be adversely affected by a defeat of the tax increase. In general the answer was "no," they did not vote because of potential economic affect.

(1) Age. Persons over 40 and between the ages of 22 to 29 from Benton county believed that the tax increase would have had no affect on them (Table VI). In Douglas county the only group responding by a "yes" to the question of economic affect, were persons in the 40 to 49 age group ( 53 percent). The only group registering a high "no" response were those over 60 ( 56 percent).

(2) Sex. In both counties more women than men felt that the tax defeat would not affect them (54 percent in Benton; 50 percent in Doug1as). Also, more women than men were uncertain about possible affects of a tax defeat.

(3) Residence. Interestingly, rural dwellers in Benton believed that they would not be affected ( 80 percent), while in Douglas people living in similiar areas believed they would (50 percent). In general, persons living in cities or urban areas in Benton county believed that 
TABLE VI

\section{TOTAL TALLY AND PERCENT OF RESPONDENTS \\ NAMING FISCAL IMPACT}

Would there have been a fiscal impact on you had the cigarette tax measure been defeated? *

\begin{tabular}{lccccccccc}
\hline & \multicolumn{2}{c}{ YES } & & \multicolumn{2}{c}{ NO } & & \multicolumn{2}{c}{ UNCERTAIN } \\
& N & PCNT & N & PCNT & N & PCNT \\
& 29 & $48 \%$ & 28 & $48 \%$ & 11 & $4 \%$ \\
Benton county & 24 & 35 & 26 & 37 & 14 & 28 \\
Dougl as county & & & & & & & & \\
\hline
\end{tabular}

* Reasons for yes-no response to this question varied. Few named "cost of smoking" as a reason for their opinion of fiscal impact. 
they would not be affected, whereas Douglas county urban dwellers did not.

(4) Education. The largest percentage of respondents in Benton who believed there would be a fiscal impact on them were people with post-college educations The se persons bel ieved that they would experience some affect ( 67 percent) probably as a result of cuts to higher education. In Douglas county the same percentage of those with postcollege educations, principally persons in medical or legal professions, believed that defeat of the tax would have no fiscal impact on them (67 percent), while those with college educations felt, more than any other group, that there would be an affect ( 45 percent). Those who thought that the tax would have no impact on them were respondents with less than a high school education in both counties (50 percent in Benton; 60 percent in Douglas).

(5) Occupation. The only occupational group believing that they would be adversely affected by defeat of the tax were persons employed in professional or technical fields in both counties (64 percent in Benton; 48 percent in Douglas). All other groups felt themselves to be unaffected. Retired persons (71 percent in both counties) were the largest occupational group in this category. Housewives were about equally divided between "yes-no-undecided" responses, particularly in Douglas county; suggesting that confusion was present in relation to the implications of the tax on property tax relief, school costs, and cuts to state agencies.

(6) Income. Persons with incomes over $\$ 15,000$ in Dougl as county answered "yes," there would be a fiscal impact, for a variety of reasons ranging from "hate others who smoke," to "if not this one, then an 
increase in some other tax." In Benton county the highest "yes" response was in the $\$ 5,000$ to $\$ 9,000$ range (50 percent). Again, the data reveals a surprising fact: persons from both counties with incomes less than $\$ 5,000$ felt defeat of the tax would not affect them. These are the people who might have lost the most through cuts to property tax relief providing for increased relief to low income families 12 and retired persons.

(7) Professional or Union Membership. Only in Benton county is there a large concentration of state and public employees. In only this county did a high proportion of organization members believe they would have been affected by a defeat of the tax increase ( 55 percent). In Douglas it was largely non-members who saw personal cost in a negative vote $(41$ percent)

(8) Voting Patterns. Those persons in each county who by their own statements vote in every election registered the least number of undecided responses in answer to the question of "Will you be affected?" Among those who vote most of the time, there was slightly more indecision (27 percent in Douglas; 32 percent in Benton) suggesting again that among the less informed, less frequent voters, confusion regarding critical implications of the tax increase was present.

\section{Important Issues}

Voters were asked the two reasons most important to them in their decision on how to vote in the cigarette tax increase. The reason for asking the question was two-fold: (1) to determine in general terms why they voted as they did, and (2) to discover to what extent voters were influenced by the issues selected as arguments on both sides of the 
campaign.

A significantly large group in both counties named "continued property tax relief" as the most important reason they favored the tax (53 percent in Benton; 60 percent in Douglas). Those voting "no" did so largely because they felt the cigarette tax was a form of regressive taxation with those least able to pay carrying a disproportionate share of the cost ( 63 percent in Benton; 62 percent in Douglas).

The second most important reason named for voting "no" was the opposition claim that there was "no guarantee of property tax rel ief" (54 percent in Benton; 54 percent in Douglas). Campaign coordinators supporting the ballot measure had argued that property tax relief would be cut if the tax failed. Opponents misrepre sented the effect by saying that if the tax passed, the entire property tax relief fund would be completely abolished. Based on voter response to the survey query on this issue, people in both counties remained confused about the accuracy of campaign claims.

The second most important reason for voting "yes" was the "threat to Basic School Support" argument (35 percent in Benton; 28 percent in Dougl as), although the argument that "smoking is dangerous" was nearly as important to Benton county voters ( 30 percent) and more important to those from Douglas county ( 37 percent).

Apparently the argument that tobacco interests from outside the state would benefit more than Oregonians by a defeat of the tax was of less relative interest in both counties. It was the least of ten reason mentioned for voting "yes," which conforms to the early findings by the professional polling agency which que ried voters on the same issue. 
The relatively least important reason for voting "no" was the argument that "taxes were al ready too high on cigarettes," which again is generally consistent with Oregon's ranking as one of the lowest in the nation for taxes on cigarettes.

Important Sources of Political Information

General Attention to Information Sources. Television viewing behavior in both counties appears to be similiar: 62 percent watch television in the evening only; 14 percent rarely watch; 11 and 13 percent respectively (Benton and Douglas county) watch television most of the time (Table VII). This includes persons in each of the population categories. In Benton, all ages, persons of both sexes, and at each educational level prefer to watch television only in the evening. More people under 39 say they rarely view television and then only for the news. Douglas county respondents follow the same general pattern. In Benton, 92 percent of regular voters read the newspapers daily while in Douglas county respondents indicate an 83 percent incidence of daily newspaper readership. Not surprising is the finding that those who regularly vote also regularly attend to newspaper coverage of current events. Again this holds true for persons of both sexes, each age and occupational group.

Attention to Campaign Messages. Both county sample populations report that most of their information on this ballot measure was obtained from, first, regular news reports, and second, radio and television advertising. The Voters' Pamphlet and conversations with friends or relatives were third and fourth in importance, with conversations named as slightly more important to Douglas county voters. 
TABLE VII

GENERAL ATTENTION TO TELEVISION AND NEWSPAPERS

RELATED TO EACH COUNTY

I. TELEVISION

Most of the time
Daytime
Evenings
News only
Rarely
Never
No Response
$\quad$ Total

II. NEWSPAPERS

Daily

Most days

Once a week

Several days a week

Less than once a week

Never

No response

$\begin{array}{rcrc}8 & 11 \% & 9 & 13 \% \\ 0 & 0 & 0 & 0 \\ 44 & 62 & 43 & 62 \\ 5 & 7 & 3 & 4 \\ 10 & 14 & 10 & 14 \\ 1 & 1 & 0 & 0 \\ 3 & 5 & 4 & 7 \\ 71 & 100 \% & 69 & 100 \%\end{array}$

Douglas

\begin{tabular}{llll}
$\mathbf{N}$ & PCNT & $\mathbf{N}$ & PCNT \\
\hline
\end{tabular}

Total

$\begin{array}{rcrc}65 & 92 \% & 57 & 83 \% \\ 3 & 4 & 6 & 9 \\ 1 & 1 & 1 & 1 \\ 1 & 1 & 3 & 4 \\ 0 & 0 & 0 & 0 \\ 0 & 0 & 0 & 0 \\ 1 & 2 & 2 & 3 \\ 71 & 100 \% & 69 & 100 \%\end{array}$


Regular voters said the least important channels for obtaining information was public debates or speeches. The limited attendance at the state wide series of meetings attested to by meeting sponsors bears this out However, Douglas county respondents, when asked which group they viewed as most influential in campaigning, replied that it was legislators. Since the majority of public endorsements by member's of the Oregon legislature came from press reports of speeches made at public meetings, it appears that public debates were important, but only as a means for relaying information through the more frequently used medium of the press.

\section{Channels of Influe nce}

Voters were asked, "What information sources were the most important in their decision on how to vote?" Two sets of responses were proviced. The first included typical channels for disseminating campaign information, television or radio advertising, public speeches, regular news reports, organizational newsletters, or conversation. The second set 1 isted personal influence sources such as the husband or wife, parents, neighbors or friends, community leaders.

The purpose of this question was to discover which channels of influence in both categories were most important in election choices.

General Channels. Only 16 persons in the Benton sample and nine in Douglas said that they attended public meetings or debates on this issue. of these approximately the same number voted for or against the measure, indicating little in the way of positive or negative influence from such meetings .

The largest number of respondents in the sample said that they 
were influenced by reading regular news reports ( 58 percent in Benton; 50 in Douglas); and of these, 76 percent in Benton and 48 percent in Douglas voted "yes" (Table VIII). In other words, the newspaper reports were first in importance as information channels for those voting "yes" in both counties. As influence sources, newspapers were only third in importance to residents of Douglas.

The chief influence source named in Douglas county was the Voters' Pamphlet (61 percent). For those voting against the tax in Douglas, conversations with friends ranked first (58 percent); in Benton county, the Voters' Pamphlet (41 percent).

Compared to Benton county, Douglas is a media isolated area. Apparently information sources critical to the "yes" vote in Benton, were unavailable to Douglas voters. Regular news reports were more limited in Douglas because of the smaller circulation of the large Portland dailies. Radio and television advertising supporting the tax were almost totally absent. This may account for the greater dependence of Douglas county voters on the Voters: Pamphlet (61 percent named it first in influence) and conversation with friends (ranked second in importance at 52 percent).

\section{Other Influence Sources}

Questions designed to discover the most important influence source in vote decisions were those asking about the typical campaign channels al ready mentioned, and those asking about influence sources from persons both public and private: family members, friends, community leaders, and public officials on a state level (the governor, secretary of state, 
TABLE VIII

INELUENCE CHANNELS FOR CIGARETTE TAX MEASURE RELATED TO YES-NO VOTE IN EACH COUNTY*

\begin{tabular}{|c|c|c|c|c|c|c|c|c|}
\hline \multirow{3}{*}{. } & \multicolumn{4}{|c|}{ BENTON } & \multicolumn{4}{|c|}{ DOUGLAS } \\
\hline & \multicolumn{2}{|c|}{ YES } & \multicolumn{2}{|r|}{ No } & \multicolumn{2}{|c|}{ YES } & \multicolumn{2}{|c|}{ No } \\
\hline & $\mathbf{N}$ & PCNT & $\mathbf{N}$ & PCNT & $\mathbf{N}$ & PCNT & $\mathbf{N}$ & PCNT \\
\hline Advertis ing & 33 & $67 \%$ & 16 & $33 \%$ & 24 & $48 \%$ & 26 & $52 \%$ \\
\hline Voters Pamphlet & 23 & 59 & 16 & 41 & 19 & 61 & 12 & 39 \\
\hline Speeches or Debates & 3 & 60 & 2 & 40 & 1 & 50 & 1 & 50 \\
\hline Newspaper Reports & 44 & 76 & 14 & 24 & 24 & 48 & 26 & 52 \\
\hline Organizational Nsltrs & 12 & 75 & 4 & 25 & 5 & 56 & 4 & 44 \\
\hline Talking with Friends & 27 & 71 & 11 & 29 & 14 & 42 & 19 & 58 \\
\hline Other & 3 & 75 & 1 & 25 & 0 & 0 & 1 & 100 \\
\hline
\end{tabular}

* Includes total responses in each category of influence channel and for the yes-no vote 
agency heads, etc.). In Both counties the spouse, friends and public officials were ranked highest in importance.

More people in both counties ranked influence from a husband or wife as first in importance, public officials and friends second and third respectively. But for people voting "yes" in Benton, leaders were the most important influence ( 93 percent). In Douglas county, "yes" voters looked chiefly to a spouse for direction (50 percent), with community officials and leaders also important, although fewer people named this group (Table IX).

The large number of public endorsements and private campaigning performed by officials and leaders during this campaign may account for the surprisingly higher ranking of officials over personal influence through social contacts--particularly in Benton. Local leaders were relatively inactive in Douglas, which may explain the high rank order of state officials specified as influential in that county. ${ }^{14}$ Apparently the activity of local and state influentials communicated to the voters their concern that the measure pass.

\section{Group Roles}

It was deemed important to know how the public viewed the activity performed by special interest groups in the campaign. The field investigation revealed that college youth were active, particularly within the institutions they attended; that legislators publicly endorsed the ballot measure; and that employees in higher education and leaders of state and Iocal OEA and OSEA units worked in a variety of ways to assure passage. Senior citizens organizations did little beyond lend their endorsement and̉ name to a coalition cause group. 
VOTER RANKING OF PERSONAL INFLUENCE SOURCES

A. Number of total influenced by various classes rank ordered.

Benton County

N (R)

$\begin{array}{lrl}\text { Spouse } & 37 & 1 \\ \text { State Official } & 22 & 2 \\ \text { Friends } & 31 & 3 \\ \text { Community Leader } & 14 & 4 \\ \text { Community Ofcl } & 12 & 5 \\ \text { Parents } & 11 & 6 \\ \text { Church Ldr } & 9 & 7\end{array}$

Douglas County

$N \quad(R)$

Spouse
Friends
State Official
Community Ldr
Parents
Church Ldr
Community Ofcl

Spouse

$32 \quad 1$

162

$13 \quad 3$

84

$7 \quad 5$

$7 \quad 6$

$\begin{array}{ll}7 & 7\end{array}$

B. Rank order listed in Table IX-A is contrasted with the \% of Yes votes as influenced by various classes

\section{Benton County}

Community Ldr

Parents

Community Ofcl

Church Ldr

State Ofcl

Friends

Spouse

$\begin{array}{ll}93 \% & 4 \\ 91 & 6 \\ 83 & 5 \\ 77 & 7 \\ 73 & 2 \\ 71 & 3 \\ 70 & 1\end{array}$

Spouse
Community Ldr
Community ofcl
State Ofcl
Parents
Church Ldr
Friends

Douglas County

$50 \% \quad 1$

$50 \quad 4$

$50 \quad 6$

463

$43 \quad 5$

$43 \quad 5$

$37 \quad 2$


Voters were asked which of these groups were most influential in the election outcome of the election in their areas: senior citizens, college students, teachers, state employees, state legislators, businesses, higher education, the governor. It was this question that revealed the greatest difference between the two sample counties.

Benton respondents named higher education as the most important and influential group, college students as second in importance, and members of the state legislature third. Douglas county felt state legislators were first, the governor second, and higher education third. In view of actual campaign activity performed by representatives of these groups, the voters appear to have been cognizant of group efforts.

State employees were ranked fourth in Benton county whe re they actually performed a number of campaign functions, but since many members of the OSEA are also on the Corvallis campus, the categories of higher education and state employees may be said to overlap. A distinction between the two interest groups is narrow and cannot be expected to be clear to survey respondents. (See Table $\mathrm{X}$ for ranking of influence)

\section{Summary of Influence Sources}

Based on the survey findings, influence sources important to the voters in this election were (1) relatives, (2) friends, and (3) local and state leaders. From this we can say that direct personal influence within social groups remained critical in persuasive effect, but the greatest percentage of persons who voted "yes" in Benton county said they did so because of influence outside of the primary group.

Impersonal information sources chiefly used were (1) newspaper 15.

reports of events or pseudo events, (2) radio and television advertising, 
TABLE X

\section{RANKING OF GROUP INELUENCE}

"Which groups were most important to the outcome of the election in your area?"

Groups

Higher education

College Students

State Legislature

State Employees

Teachers

Governor

Businesses

Senior Citizens

Other
Benton

23*

19

18

16

14

11

9

9

1 $\frac{\text { Douglas }}{\#}$

17

10

24

7

9

20

6

7

6

* Responses include total named. 
and (3) editorial information. The only groups relying heavily on the Voters' Pamphlet were the "yes" voter in Douglas, and the "no" voter in Benton.

Group influences were thought to be (1) higher education, (2) students, and (3) state legislators in Benton county; (1) legislators, (2) the governor, and (3) higher education in Douglas.

In both counties most of the people who voted "yes" did so because they believed that defeat of the tax would mean (1) less property tax relief, and (2) cuts to state agencies, not because they felt there would be a personal impact on them from a tax defeat. Persons voting "no" did so largely because they believed that (1) the tax was regressive, and (2) that it was too mich like a sales tax.

"Yes" voters cited as the second most important reasons (I) the possibility of cuts to public schools, and (2) the fact that smoking is dangerous therefore an an appropriate commodity for taxation. The "no" voters used the opponent argument that there was no guarantee of property tax relief as their second most important reason for opposing the $\operatorname{tax}$.

A high proportion of persons in both counties felt that the issues were muddy and that fiscal impact of a tax defeat on them was unclear. Maturally those voting affirmatively believed preponent arguments were wll presented and free of confusion while the opponent cause was unclear; those registering dissenting votes believed the opposite.

\section{LEADERSHIP SURVEY}

Nearly every known participating legislator and interest group leader was mailed a questionnaire requesting information similar to that 
asked the voters plus specific questions directed at obtaining testimony on their role in the campaign. Only those legislators who were active through coordinating work or public speaking appearances in favor of the tax were queried: seven responded. Sixteen organizational leaders were sent questionnaires and of these, fifteen replied. Theree fore it is felt that the responses from all leadership sources represent accurately those persons involved in or close to the supporting side of the campaign.

\section{Leadership Involvement}

Both legislators and interest and cause group leaders were asked how they viewed their role in the campaign, the tasks they performed, and the manner by which they became involved in the effort to pass the state ballot measure (Table XI).

Legislators responded to the question of, "What was your role in the campaign?" by naming legitimizing of the campaign effort as most important. Of secondary importance was their role as information sources, according to the majority of responses. Cause group leaders asked the same question said their primary role was legitimizing the campaign on the state level and initiating activity on both a state and local level. The answers were consistent with roles un oovered in the field investigation. They saw themselves as information sources to the general public as only moderately important.

In response to "What tasks did you or your group perform in the campaign?" four legislators replied that their primary job was the making of public statements that were quoted in the press. The other three felt that the chief task they performed was fund raising. 
TABLE XI

LRADERSHIP ROLES AND TASKS PERFORMED

\begin{tabular}{|c|c|c|}
\hline ROLE & $\frac{\text { Legislators }}{\#}$ & $\frac{\text { Leaders }}{\#}$ \\
\hline \multicolumn{3}{|l|}{ Legitimizer: } \\
\hline State Level & 5 & 5 \\
\hline Local Level & 0 & 5 \\
\hline \multicolumn{3}{|l|}{ Initiator: } \\
\hline State Level & 0 & 7 \\
\hline Local Level & 1 & 6 \\
\hline \multicolumn{3}{|l|}{ Information source: } \\
\hline To General Public & 1 & 5 \\
\hline To Members & - & 6 \\
\hline \multicolumn{3}{|l|}{ TASKS PERFORMED } \\
\hline Fund Raising & 3 & 3 \\
\hline Mailings to constituents & 0 & $8^{b}$ \\
\hline Public Statements Quoted & 4 & 11 \\
\hline Public Speaking appearances & 7 & 7 \\
\hline Inter-organizational coordination & 0 & 6 \\
\hline Recruiting or organizing workers & 0 & - \\
\hline
\end{tabular}

ancludes primary and secondary functions named by interest group leaders.

brito members" 
Organizational leaders felt that their primary tasks were issuing public statements to be quoted in the press, mailing information regarding the tax measure to their members or other interested citizens, and the third most important function was public speaking appearances or inter-organizational coordination of the campaign.

Only organizational leaders were asked the question, "How did you become involved in the cigarette tax campaign?" (Appendix G) Six responded that it was an independent decision made by their organization's board of directors; four replied involvement occurred as a result of personal contacts by individuals or group leaders outside their organization who were already involved; and four said that involvement was a decision made independently by themselves or their organization's leadership.

Interest group leaders were also asked whether or not they would have been involved if the tax defeat meant fiscal impact on their members. Only slightly over half said they would not have been active.

\section{Information Channels and Influence Sources}

Questions parallel to those asked the voters of Benton and Douglas counties were posed to legislators: (1) informational channels important to the voters, and (2) groups most influential on the outcome of the election (Table XII).

Legislators were asked which in a series of channels were important in the election outcome: television, radio, newspaper advertising, regul ar newspaper reports, public speeches, etc. Slightly over half of the legislators queried felt that television was extremely important in the vote outcome. Also slightly more than half believed that newspaper 
TABLE XII

\section{LEADERSHIP OPINION ON INELUENTIAL INFORMATION \\ CHANNELS AND GROUPS}

\begin{tabular}{|c|c|c|c|c|c|c|}
\hline \multirow[b]{3}{*}{ INFORMATION CHANNELS: } & \multicolumn{3}{|c|}{ Legislators } & \multicolumn{3}{|c|}{ Leaders } \\
\hline & \multicolumn{2}{|l|}{ Impt } & \multirow[t]{2}{*}{$N$ Impt } & \multicolumn{2}{|c|}{ Impt } & \multirow[t]{2}{*}{ N Impt } \\
\hline & & & & & & \\
\hline Television & 5 & & 2 & 5 & & 4 \\
\hline Radio & 3 & & $\overline{0}$ & 4 & & $i$ \\
\hline Newspaper ads & 3 & & 0 & 3 & & 0 \\
\hline Newspaper reports & 3 & & 4 & 8 & & 5 \\
\hline Public Speeches & 2 & & 3 & 3 & & 4 \\
\hline Door-to-door contact & $\overline{1}$ & & 1 & 3 & & 4 \\
\hline Mailings to voters & 1 & & 1 & 3 & & 3 \\
\hline Personal contact & 3 & & 2 & - & & - \\
\hline GROUPS & $\underline{1}^{*}$ & $\underline{2}$ & $\underline{3}$ & $\underline{1}$ & $\underline{2}$ & 3 \\
\hline Higher Education & 1 & 2 & 4 & 1 & 1 & 12 \\
\hline Public Employees & 0 & 1 & 6 & $i$ & 2 & 10 \\
\hline Public education & 0 & 4 & 2 & 3 & 4 & 7 \\
\hline Businesses & 3 & 3 & 0 & 6 & 4 & 2 \\
\hline Senior citizens & 3 & 2 & 0 & 6 & 5 & 3 \\
\hline Youth & 1. & 2 & 2 & 2 & 4 & 8 \\
\hline Organized Labor & 4 & 1 & 1 & 5 & 7 & 1 \\
\hline Other & 0 & 0 & $i$ & 1 & 0 & 1 \\
\hline
\end{tabular}

₹I=Least important

2=Moderately important

$3=$ Extremely important 
advertisements were moderately important; and the same proportion felt that news reporting and editorial support was least important.

Interest group leaders were asked the same questions regarding important information channels. They believed that television was most important, followed by regular news reports. These same leaders felt that of all channels available to the voters, radio and door-to-door campaigning were least important.

As to the influence of special interest groups on voter choice, legislators felt almost unanimously that public employees and higher education were extremely important. Public school educators and organized labor were felt to be moderately important, and senior citizens and business interests least important. Organizational leaders felt that higher education, public employees, and young people were most important. Only moderately important were senior citizens, organized labor, and public educators. Business was considered unimportant. With respect to questions of interest group influence the responses of interest group leaders were only somewhat closer in assessing influence than were state legislators. The voters too viewed higher education as critical in the vote outcome, however all classes of state employees were rated higher.

Both legislators and leaders were asked to rate the proponents on clarity of the issues. A definite majority of both legislators and interest group leaders felt that the issues were only somewhat clear (all legislators; four out of seven replies of leaders). The same question was asked regarding clarity of the issues presented by the opponents of the tax increase. Again, a majority from both groups felt that the opponents were not at all clear in explaining the issues; a finding 
consistent with what we might expect from leadership supporting the ballot measure, but not altogether supporting the methods used in the campaign.

\section{Importance of Issues}

The response to the question, "Which issues were important in the voters decision on how to vote?" offers the most striking contrast between the voters and leaders active in the campaign (Table XIII). Legislators named cuts to state agencies, property tax relief, and increased tuition at state colleges and universities as extremely important to the "yes" vote. They named as only moderately important the issue of cuts to Basic School Support and property tax relief.

Least important to the legislators was the issue of out-of-state tobacco interests gaining more from a tax defeat than the Oregon electorate. Few felt that the issue, "smoking is dangerous," was a factor in election choices, whereas voters from both counties named it as second in importance as a reason for voting "yes."

Organizational leaders felt that property tax relief was most important and second only to a threatened cut to state agencies. Again, the survey found that organizational leaders are more accurate in assessing voter reasons for supporting the tax.

The question of which issues were important to the "no" vote was al so asked. Legislators felt that similarity of the cigarette tax to a sales tax was extremely important in the "no" vote, as was a judgment that most voters were against all taxes. Fewer than half of the legislators queried felt that voter resistance to all taxes was of even moderate importance. Most felt that the issue of least importance was 
"threat to property tax relief." This was in contrast to the voters who believed that threats to property tax relief was a primary reason for opposing the tax, apparently believing the opposition claims. None of the legislators felt that the issue was most important and four said it was least important of all suggested.

The leadership representing interest and cause groups felt that the issue of "regressive taxation," was the most important reason voters said "no". This is consistent with voter survey results. The second most important reason named was that "all taxes are too high." Third most often mentioned issue was the argument that the cigarette tax was too similiar to a sales tax. None of the leaders questioned felt that "danger to property tax relief" was of any significance in voter decisions

Summary of Leadership Survey

One of the chief reasons for conducting a leadership survey that paralleled one polling the voters, was to discover the extent to which their judgments conform to those held by the Oregon voter. The study asked if leaders are accurate in assessing why voters decided to vote for or against the tax. The data reveals that certain important discrepancies do exist between the leadership elite and regular voters in regard to (1) their opinions of political communication channels that are most important to the voters, and (2) the importance of specified issues in election choice.

The voters were asked how they, obtained their information and the sample replied that the most important source of information on the sales tax was newspaper reports and conversations with friends. Oregon's 
political elite were at odds on this question, both with each other and with the voters.

The voters were asked their reasons for voting yes or no. They said key issues in their decision to vote "yes" were (1) need for continuing property tax relief, (2) threats to the Basic School Support fund, and (3) the danger of smoking. The "no" voters answered (1) the cigarette tax is a regressive tax, and (2) there are no guarantees of property tax relief. Leaders, particularly legislators, felt that other issues were more important to the voters. None thought that "smoking is dangerous," or "threat to property tax relief" were issues affecting the vote.

Not at all surprising was the finding that the public felt the issues were clear only if they voted "yes"; unclear if they voted "no." Leadership felt generally that the campaign on the proponent side had made the issues clear to the voter, but all of those polled favored the $\operatorname{tax}$.

Voters believed that the most influential groups active in the campaign were (1) higher education, (2) students, and (3) state employees. In this, leaders were agreed, although there was a variety of opinion difference between interest group leaders.

\section{SURVEY CONCLUSIONS}

While the data cannot fully answer each question posed in the statement of thesis objectives, the following general conclusions have been drawn regarding the voters surveyed:

1. Regular voters use in general the same channels for obtaining politically relevant information: 
regular newspaper reports, radio and television advertising, and the Voters: Pamphlet.

2. Voters of higher education and income depend more on newspaper coverage of campaigns; lower socioeconomic groups rely more on "low effort" radio and television advertising. ${ }^{16}$

3. The chief audience for political campaign messages in general and this campaign in particular, seems to be those between the ages of $30-49$, in the middle income levels, and who are socially active in their communities.

4. Attention to campaign communication is not directly related to voting frequency. Regul ar voters over 60 years of age rarely attend to the usual campaign channels. 17

5. Regular voters are accurate in assessing the campaign participation of special interest groups.

6. It is more difficult to convince lower income population groups (of all ages) of complex facts in fiscal legislation, and this tax measure in particular.

7. Fear appeals can have a "boomerang" effect. The inaccuracies of campaign messages on both sides in this campaign resulted in voter confusion, especially the real impact of the ballot measure defeat on the General Fund.

8. Voters are more likely to go to the polls if the issues are accurately presented. Where there was less confusion there was a greater turnout and a greater percentage of "yes" votes. While these may not be causally related, there is evidence to suggest that uncertainty and negative votes are. ${ }^{18}$

By comparing the voter survey data to that derived from the leadership survey these conclusions have been drawn:

1. There is little congruence between what regular voters believe to be important issues and what public and private influentials believe.

2. While regular voters are accurate in assessing the campaign participation of special interest groups, the leadership in these groups differ in regard to the same question.

3. Interest group leaders are somewhat more accurate 
in ascribing motives to the voters than are legislators.

4. Most legislators were aware of inaccuracies in the campaign from the political committees on both sides of the issue, and felt them to be a negative element in the campaign effort. 


\section{Notes}

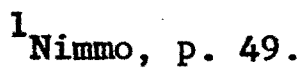

"Official Voter Abstract, Special Election 1972."

3U.S. Census Bureau, Oregon, 1970.

${ }^{4}$ Oregon Blue Book 1971-72, p. 181.

${ }^{5}$ Ibid., . 185.

${ }^{6} \mathrm{KATU}, \mathrm{KOIN}-\mathrm{TV}, \mathrm{KGW}-\mathrm{TV}, \mathrm{KPTV}$, and educational station KOAP-TV: Hamilton-Landis and Associates, Inc., T.V. Factbook (San Francisco, Cal ifornia, January, 1972).

7McCann-Erickson, Inc., "Oregon Newspaper Coverage: Dailies and Weeklies" (Portl and, Oregon, September 9, 1968).

${ }^{8}$ The chief source of information from newspaper coverage in Dougl as county is the Roseburg News Review; in addition the county has four small papers published weekly (circulation ranging from 760 to $2,096)$.

9"Official Vote Abstract:"

${ }^{10}$ Campbe11 and Cooper, PP. 20-23.

11"Official Vote Abstract."

${ }^{12}$ If two percent reductions had been imposed, reduction in property tax relief would have been approximately $\$ 8.53$ for a tax payer in this category.

13 Kennedy pol1.

${ }^{14}$ According to past studies on persuasive influence, personal influence from "opinion leaders" or influentials within the primary group were named as most important; see for instance, Campbell and Cooper; Al an Casty, ed., Mass Media and Mass Man (New York: Holt, Rinehart and and Winston, 1968) , P. 163; Elihu Katz, "The Two-Step Flow of Communication: An Up-To-Date Report on an Hypothesis," Public Opinion Quarterly, Vol. 21 (Spring, 1957), p. 61-78.

${ }^{15}$ For a discussion of how campaigners frequently manufacture events, or pseudo-events in order to obtain publ ic attention, see Nimmo, p. 46. 
16 For a review of studies relating age and education to media preference, see Nimmo, p. 117:". . . less educated persons are more likely to believe a television news story over a newspaper version. Younger persons accept television versions as believable. . . Those assigning high credibility to newspapers are generally men with at least some college, residing in an urban area, professional or in a reasonably high-status occupation, and of weak partisan identification."; Berelson credits "personal ism" in the communication act to its effectiveness: "The greater effectiveness of radio over newspapers derives to some extent from its greater "personalism.": Bernard Berelson, "The Variable Influence of Communication," in Casty, ed., Mass Media and Mass Man (New York: Holt, Rinehart and Winston, Inc., 1968), p. 163).

${ }^{17}$ We may infer that personal influence is correspondingly more critical to those in this age group.

$18_{\text {Kennedy, interview. }}$ 
CHAPTER VI

\section{CONCLUSION}

The purpose of this study was to bring together the full range of activity in the 1971-72 cigarette tax referendum campaign. The investigation included an analysis of (1) past tax elections in Oregon, (2) the events leading to a referendum on the cigarette tax, (3) the manner by which public and private individuals and groups became involved, (4) the communication initiated by campaigners, and (5) the voter's reaction to general campaign strategies.

The thesis hypothesis argued that the critical variable in the success of the 1972 cigarette tax campaign was the involvement of major socioeconomic interest groups. The proposition was tested in the field investigation by examining activities of individuals and groups which were designed to manipulate the behavior of the voters to the campaigners' advantage. In other words, each major element in the campaign was studied: (1) the campaigners, (2) their strategies, (3) the setting, (4) the voters, and (5) election results.

The purpose of the final chapter is to briefly review what was revealed by the investigation and draw certain generalizations in support of the thesis hypothesis.

\section{SUMMARY}

The manner by which the cigarette tax campaigners tried to "sell" the electorate was only in some respects parallel to what is described 
by campaign researchers as the "usual method" of passing a state ballot measure. There was 1 ittle debate regarding "technicalities of funding." When budgets are cut, went the reasoning, services to the people are cut. If this logic failed to capture the favor of the voters; there were others: nonsmokers would not have to pay yet would receive the same services gained by those who did. Attempts were made to shift attention away from the issue of "regressive taxation": smokers did not have to smoke, so it was an optional tax rather than a "selective tax."

These and other arguments appeared in the campaign literature and media reports of campaign events. They were del iberately and carefully selected, and used by institutional leaders in many segments of Oregon's political life. In the referendum campaign, public appearances, personal contacts, and mass communication channels were utilized by state officials, the governor and state legislators. Strategies were suggested, debated and implemented by the State Committee. In addition, other approaches we re used by independent campaigners representing large pressure and cause groups.

The State Committee said that the fear appeals were deliberately chosen and were necessary to mobilize groups that could be hurt by a revenue refuction. But these same fear appeals, compounded by similiar methods issuing from the opposition, may have created voter confusion, and more important, voter distrust.

The coordinators also said that there was no effort to respond to opposition attacks in the implementation of the pre-established strategy; but certain state officials did respond and gained wide public atten- 
tion when they charged the opposition with deliberately misleading and and false statements, and equally wide attention when they in turn were charged with misconduct in the performance of their duties.

Campaign coordinators said that the time limitations made for a tightly knit campaign. Only a few people made key decisions on slogans, timing, and channels that would be used to disseminate the arguments. But again, an analysis of the campaign demonstrates a contradiction. While there was no time for internal organizational dissention, leadership fragmentation did occur in the absence of any concerted efforts to bring them together. Each group carried out its own strategy decisions. The interest group leaders were not permitted to see results from the public opinion polls, they were not consulted on the way funds should be spent, and they were not asked their opinions about the best structuring of the arguments. As a result they felt no particular obligation to conform to State Committee decisions. There is a very real possibility that had the campaign lasted longer, latent dissatisfactions with the course taken by the State Committee might have become manifest and created serious problems for the united effort.

The fragmentation of activity carried out by different interest and cause groups makes analysis difficult. Some leaders said that .. student contribution was of critical importance; others that participation by state employees was the deciding factor. Most informants had different notions about what contributed to success: personal influence through individual contacts, said some leaders; mass persuasion utilizing metropolitan Portland media, said others. But the voter disagreed with both and said that they obtained the bulk of their information from regular newspaper reports. 
Media reports generally dealt with matters peripheral to the issues: (1) synthetic opposition surfacing in the form of committees designed to counter the influence of the youth-aged coalition, (2) demands for apologies for corrupt practices violations coming from both sides of the battle line, and (3) leading supporters of the tax labeled "prostitutes of the governor" by the opposition, and leading opponents called "carpetbagging out-of-state 'ers" by the proponents.

In the 1971-72 cigarette tax campaign only one factor remained constant-resistance of Oregon voters to taxes. And yet, even this long-time tradition was challenged. A state official said in an interview immediately following the election that "the public has finally accepted the fact that government is not adequately funded. They believe something has to be done."

It was for the purpose of resolving some of the remaining causal questions that the voter-leadership survey was undertaken as a followup to the field investigation. The purpose was to discover voter opinions regarding the effectiveness of communication generated by special interest groups and their reasons for voting as they did. These opinions, described in the previous chapter, assume importance in connection with the following conditions which existed in Oregon at the time of the campaign:

1. The cigarette tax increase was the only immediately available solution to a serious budget deficit. An alternative source would have required another special session, another 90 day waiting period, and the threat of another referendum.

2. This was the first recent tax measure with support from legislative leaders of both political parties: Democrat and Republican Senate leaders; Speaker of the House; and house members from both parties. 
3. The tax revolt in Oregon was not the product of depressed conditions, according to all economic indexes, but reflected a nation wide dissatisfaction with property taxes. 3

4. This was the first state campaign conducted under the federal constitutional amendment granting the vote to those between the ages of 18 and 21 .

5. It was the first time Oregon politics had witnessed a coalition of young and old people working side by side with large permanent interest groups.

6. It was the first time that a concerted effort was made by members of Oregon's higher education community in support of a general tax.

7. Campaign strategy called for directed appeals to special interest groups and attempted to define issues in terms of fiscal impact on special groups.

8. In each of the 12 counties where the tax increase passed there was either a major institution of the state system of higher education, a community college, or an important complex of state government. But there were also colleges in five counties where the tax was defeated: Jackson, Coos, Douglas, Cl atsop and Deschutes.

Certain inferences should also be included as part of the analysis:

1. There was a great amount of public consternation over misrepresentation of the "facts," resulting in extensive voter confusion about the truthfulness of campaign messages.

2. Public confusion was most evident in the reasons for the "no" vote, and in voter judgments regarding the fiscal impact of the cigarette tax defeat on them.

Taken together, facts and inferences suggest that a great many variables were at work in the vote outcome. Without a comprehensive survey of the entire state we cannot say with certainty that the measure passed because of, or in spite of the campaign. However, comparisons of voter opinions in two Oregon counties provides evidence that strongly suggests the campaign was a qual ified success. 
Relation of Field Investigation to Survey Results

The survey findings reveal some serious weaknesses in the cigarette tax campaign. Rather than countering opposition statements that the property tax relief account would be eliminated if the tax passed, supporters of the measure on a state wide level continued with their initial campaign strategy: suggesting that the two percent cuts "could be" leveled at one or several agencies rather than across-the-board to all services as provided for in a companion bill to H.B. 3064 . As a result, many voters remained uncertain about the property tax relief question, and those who do not always vote in special elections, responded to their uncertainty by voting "no."

This information, taken with data provided by the professional pol1 ing agency imnediately following the election, provides evidence that certain strategy decisions worked to prevent a larger victory.

Countering the voter indecision were the strong appeals made to and by members of both formal interest groups and temporary cause groups-notably the youth-aged coalition and Friends of Higher Education. These organizations attempted direct personal influence by instigating activity on a local level, working to convince members that they would be directly affected, by the two percent cuts, not "selective cuts," if the tax were defeated. The arguments they used included: (1) budget cuts to (a) higher education, (b) departments of Human Resources and Environmental Quality, (c) State Basic School Support, (d) community college operating reimbursements and (e) direct property tax relief. The same arguments were used by each group with an emphasis placed on the one most relevant to the particular audience.

Voters were influenced by these arguments, and the survey revealed 
that those who voted "yes" did so largely because of them. Moreover, voters were aware of interest group activity in their respective counties and named higher education, students and state employees as most influential in the campaign.

Voters were influenced by their elected leaders, the governor as well as legislators, and articulated this influence on the questionnaires returned. The survey al so demonstrated the importance of contributions made by state and local influentials. There is evidence to indicate that although leadership endorsements were influential, particularly to those voting "yes," their reasons for favoring the tax were not.

\section{CONCLUSIONS}

The thesis hypothesis stated that the crucial variable in the success of the referendum campaign was the involvement of special interest groups. Interest groups were defined as permanent pressure groups and temporary cause groups. The following pressure groups were most active: the OSEA, the OEA, and Friends of Higher Education. The most publicized cause group was the youth-aged coalition. Business interests and organized labor did contribute to the campaign effort, but to a lesser extent; the former donating money and several volunteers, the latter a campaign contribution and public endorsement.

While the data cannot fully answer every question posed in the statement of thesis objectives, the central proposition was supported. The investigation revealed that interest groups were effective, chiefly because of the many roles they performed in each phase of the campaign: as initiators of campaign activity, as legitimizers, as fund raisers, and as channel sources for disseminating information to both their own 
members and to the general public.

(1) Initiators. The OSEA and youth-aged coalition was instrumental in initiating a pro-tax campaign and were, with the governor's office, responsible for establishing an official campaign committee. Although they had little to say about strategies developed by the State Committee, without them a central campaign committee would not have been possible.

As initiators they opered up the channels of communication by defining the problem and relaying this information to other potentially affected groups and individuals. They also performed a legitimizing function as the formal organizational leaders publicly endorsed the tax measure in the early stages of the campaign. Other roles they performed were perhaps more significant, but the early endorsements established a precedent for involvement and were critical in later mobilization of affiliated local groups and the snow-balling endorsements by other influentials that followed.

(2) Message disseminators. The most important role performed by all interest groups was as channel source. Bach group had existing mechanisms for getting information to a large number of a people within a mininum period of time. Since the campaign was necessarily of such short duration this was doubly crucial. Each group, including the student organization, had immediately available multiple communication channels over which they had substantial control. The most important channels were printed media (newsletters, student newspapers, and various other specialized publications originating within the organization), and personal ccntacts (local legislative chairmen, presidents of local chapters 
or college student groups, affiliated organizational officers).

Many press statements were made and public speeches given in the 40 day campaign, many of which were facilitated by the interest groups. Fully half of all speeches made by state influentials were done through the sponsorship of the employee organizations. While few of the voters surveyed actually attended the public meetings, they read about them in their daily newspapers or 1 istened to quoted statements made by legislators or officials over the regular news reports on television and radio. Speeches given by faculty and students on college campuses likewise received notice in both the public press and in university publications.

(3) Fund Raisers. The availability of multiple channels, especially in higher education, made possible the third role. Permanent interest groups had existing funds available for just such a purpose and needed only the approval of their respective governing boards to release the money. Friends of Higher Education had no such ready source, and yet, because of their contacts with persons committed to quality education, were able to raise an amount almost equal to that contributed by other groups. Fund raising success went beyond support of the State Committee media effort in its effect. By obtaining small donations from many individuals, they obtained increasingly greater committment. "Get a man's dollar and you get his vote," said one campaigner. There is good reason to believe that this is true, and the mobilization of human resources was in this way advanced.

The roles were self-starting and self-perpetuating. Because there was no effort on the part of the State Comittee to involve anyone outside the immediate working team in the decision making process, the 
interest groups felt no obligation to be guided by them. Most of the groups refused to use printed 1 iterature put out by the State Committee and instead wrote and distributed their own, using essentially the same arguments concerning economic impact on specified population groups, but structured with less exaggeration and emotionally loaded language. Based on the interviews conducted in this study, we do know that persuasive messages originating with the groups had a large audience, collectively totalling in excess of 30,000 . Using the mail and personal distribution by students at Oregon college campuses, potentially eight percent of all registered voters in the state were reached.

It would be inaccurate to say that the campaign would have succeeded without media support in an area with the largest population in the state. Our survey demonstrates that radio and television advertising are important sources of information for the Oregon voter; however, media appeals would not have been possible without the fund raising activities of the interest groups.

Nor were attempts at interest group coordination carried out by the State Committee completely ineffectual. But many of the other activities of the central campaign organization had a counter-productive effect--their overstated arguments drew fire from the opposition that might have been avoided, and gave the press cause to publicize the sensational news of corrupt practices violation charges rathe $r$ than news of the substantive issues.

For all of the reasons named above we must conclude that the mediating activity of state and local influentials, through the mechanisms of special interest pressure and cause groups, provided a critical balance and made the difference in the campaign success. 
Recommendations for Future Research

Timing was a significant weakness in the design of both the field study and the voter survey. Specifically, it would have been desirable to conduct the field investigation during the actual campaign rather than some months later. The time factor was even more crucial in regard to the voter survey, although every effort was made to counter this problem. Although the sample was considered representative, other evidence suggests that many more young people voted than those represented in the survey.

An extensive voter registration drive was conducted on the Oregon State University campus. Because a majority of students return to their family homes during the summer months, it may be that many did not receive the questionnaire in time to return it by the survey deadline. For this reason, we do not have adequate information on the student vote-the issues youth felt were important, the way they leceived the ir information, or the chief source of influence on their vote decision. Future research would do well to account for seasonal residence among college youth in any study of campaign effects.

A very real need remains in local or state campaign research in many areas, particularly: perceptual differences between the leadership elite and the average voter; the long-range effects of campaign credibility on voter choice; and voting trends among population groups on referendum is sues. It would also be profitable to discover whether a particular combination of interest groups provides greater momentum and role possibilities in other state political campaigns.

This investigation revealed not only that special interest groups 
are often active in state ballot measure efforts (both as initiators and as campaign sponsors), leadership from this group are more nearly in tune with voter attitudes in every aspect of a campaign. Therefore, a more narrowly focused study on differences among the elite in their assessment of voter opinion ought to be conducted. Because a campaign is nothing more or less than the people who run it, a careful analysis of such leadership perceptions would be of real value to studies of local or state referendum campaigns.

A longitudinal study of source credibility within similiar types of campaigns likewise should be attempted. By a variety of means, the woter seeks to remind his leaders the implications of his disbelief on passage of a tax proposal, but leadership too often discounts this as a factor in election results. National as well as state leaders behave as though the voters could be won merely by deciding on the "best" slogans, the most efficient timing, and the most persuasive arguments. It would be interesting and valuable to discover how extensive distrust is among the various population groups and the extent to which distrust motivates them to vote for or against tax measures.

Many other potentially profitable avenues for investigation present themselves. Questions of the effect of membership affilliation on vote have not been adequately answered. Nor have questions regarding the effects of overlapping group membership on vote decisions. More careful analysis of the relationships of party affiliation to susceptability of influence from partisan leaders needs to be done.

\section{Summary}

Although it is clearly difficult to find conclusive answers through 
one or several research methods because of the complexity and scope of state political campaigns, this investigation has thrown some light on the influence of interest groups in a nonpartisan, state referendum campaign. All of the data obtained through both the field investigation and voter-leadership survey suggest that interest group involvement was important to the success of the campaign. We can also conclude that future successful campaigns will witness a new coalition of influentials and another combination of interest groups, perhaps differing in composition from those active in the 1971-72 effort, but combinations which will most certainly perform the same roles and make use of the same channels. A future referendum would also do well to place credibility as a top priority in planning campaign strategies. To be sure, there are always charges to be answered originating from the opposition, and issues to be structured in the most persuasive fashion. But if Oregon is ever to obtain voter approval for any proposal that goes beyond a "band-aid" solution to what has become a biennial fiscal crisis, responsible campaigning is essential. 


\section{Notes}

\section{Nimmo, P. 10 . \\ ${ }^{2}$ Post, interview.}

"Public Opinion and Taxes," Advisory Commission; "Oregon Labor Force Trends," Oregon Department of Labor (January, 1972).

${ }^{4}$ The State Committee was not defined as an interest group because it was made up of professionals paid to work in behalf of the measure and who otherwise would be unlikely to take an active part.

5Membership mailing 1 ist: OSEA, 17,000; OEA, 19,500; potential university publication readership, 54,000; potential community college publications readership, 40,000; OSBA, 2,500. 


\section{BIBLIOGRAPHY}


SOURCES CONSULTED

\section{Books}

Apter, David E. Ed. Ideology and Discontent. New York: Holt, Rinehart and Winston, Inc., 1968 .

Baus, Herbert M. and Ross, William. Politics Battle Plan. New York: The Macmillan Co., 1968.

Berelson, Bernard R, and Janowitz, Morris, eds. Reader in Publ ic Opinion and Communication. Glencoe, Illinois: Free Press, 1950.

Berelson, Bernard R.; Lazarsfeld, Paul F.; McPhee, William N. Voting. Chicago: University of Chicago Press, 1954.

Beisecker, Thomas D., and Parson, Donn W., eds. The Process of Social Influence: Keadings in Persuasion. Englewood Cliffs, New Jersey: Prentice-ilall, Inc., 1972.

Bettinghause, Erwin P. Persuasive Communication. New York: Holt, Rinehart and Winston, Inc, 1968 .

Blumer, Jay G., and McQuail, Denis. Television in Politics: Its Uses and Influence. Chicago: University of Chicago Press, 1969.

Burton, Robert E. Democrats of Oregon: The Pattern of Minority Politics, 1900-1956. Eugene, Oregon: University of Oregon Books, 1970 .

Campbell, Angus and Cooper, Homer C. Group Differences in Attitudes and Votes. Michigan: Survey Research Center, University of Michigan, 1956.

Campbell, James H., and Hepler, Hal W., eds. Dimensions in Communication: Readings. Belmont, California: Wadsworth Publishing Co. Inc., 1968 .

Cherry, Colin. On Human Communication: A Review, A Survey, and a Criticism. Massachusetts: The M.I.T. Press, 1957.

DeFleur, Melvin L. Theories of Mass Communication. New York: David McKay Co., Ind., 1970.

Eaton, Allen H. The Oregon System: The Story of Direct Legislation in Oregon. Chicago: A.C. McClurg and Co., 1912 . 
Festinger, Leon and Katz, Eilhu, eds. Research Methods in the Behavioral Sciences. New York: Holt, Rinehart and Winston, 1953.

Jonas, Frank H. ed. Politics in the American West. Salt Lake City, Utah: University of Utah Press, 1969.

Katz, Bilhu and Lazarsfeld, Paul F. Personal Influence: The Part Played by People in the Flow of Mass Communications. Glencoe, Illinois: The Free Press, 1955.

Key, V.0., Jr. A Primer of Statistics for Political Scientists. New York: Thomas Y. Crowel1 Co., 1966.

Key, V.0., Jr. Politics, Parties and Pressure Groups. New York: Thomas Y. Crowe11 Co., 1964 .

Klapper, Joseph T. The Effects of Mass Communication. New York: The Free Press, 1960.

Lazarsfeld, Paul F.; Berelson, Bernard; Gaudet, Hazel. The Peoples Choice. New York: Duel1, Sloan and Pearce, 1944.

Lewin, Kurt. Field Theory in Social Science. Dorwin Cartright, ed. New York: Harper, 1951.

Lila Acheson Wallace School of Community Service and Public Affairs. Oregon's Dilemmas: Whe re do We go from Here? Eugene, University of Oregon, May 16-18, 1968 (Second Annual Report).

Merton, Robert K. and Lazarsfeld, Paul F. eds. Continuities in Social Research. Glencoe, Illinois: Free Press, 1950.

Moodie, Graeme C., and Studdert-Kennedy, Gerald. Opinions, Publics and Pressure Groups. London: George Allen Unwin Hd., 1970.

Neuberger, Richard L. Adventures in Politics. New York: Oxford University Press, 1954.

Nimmo, Dan. The Political Persuaders. Englewood Cliffs, New Jersey: Prentice Hall, 1970.

Oregon, State of. Oregon Revised Statutes. Vo1. 2, 1971. Legislative Councel Committee. Portland, Oregon: Binfords and Mort Publishing Co., 1971 .

Scammon, Richard M. and Wattenberg, Ben J. The Real Majority. New York: The Free Press, 1960.

Shevky, Eshrev, and Bell, Wende11. Social Area Analysis: Theory, Illustrative Application and Computational Procedures. Stanford, California Stanford University Press, 1955. 
Thibaut, John W. and Kelley, Harold H. The Social Psychology of Groups. New York: John Wiley and Sons, Inc., 1959.

Wells, Al an, ed. Mass Media and Society. Palo Alto, California: National Press Books, 1972.

\section{Journals}

Bogart, Leo. "The Spread of News on a Local Event: A Case History." Public Opinion Quarterly, Vo1. 14 (1950), 769-772.

Chowdhry, Kamla and Newcomb, Theodore M. "The Relative Abilities of Leaders and Non-Leaders to Estimate Opinions of their Own Groups." Journal of Abnormal and Social Psychology, Vol . 47 (1952), 51-57.

Clausen, J.A. and Ford, R.N. "Controlling Bias in Mail Questionnaires." Journal of American Statistical Association, Vol . 4 (1947), 497511.

Converse, Phill ip E.; Clausen, Aage R.; Miller, Warren E. "Electoral Myth and Reality: The 1964 Election." American Political Science Review, LIX (June, 1965), 312-336.

Freidson, Eliot. "Communications Research and the Concept of the Mass." American Sociological Review, Vol. 18 (1953), 313-317.

Gore, William J. and Peabody, Robert. "The Function of the Political Campaign: A Case Study." Western Political Quarterly, XI (1958), 55-70.

Hites, R.W. and Campbell, D.T. "A Test of the Ability of Fraternity Leaders to Estimate Group Opinion." Journal of Social Psychology, Vol. 32 (1950), 95-100.

Katz, Eilhu. "The Two-Step Flow of Communication: An Up-to-Date Report on a Hypothesis." Public Opinion Quarterly, Vol. 21 (Spring, 1957), 61-78.

Kelman, Herbert C. "The Process of Opinion Change." Public Opinion Quarterly, Vol. 25 (1971), 57-78.

March, James G. "Group Norms and the Active Minority." American Sociolngical Review, Vol. 19 (1954), 733-741.

Oregon. Oregon Blue Book 1971-72. Compiled by Clay Myers, Secretary of State, Salem, Oregon, 1971 .

Oregon. Oregon Blue Book 1961-62. Compiled by Howell Appling, Jr., Secretary of State, Salem, Oregon, 1960. 
Oregon. Oregon Blue Book 1959-60. Compiled by Mark 0. Hatfield, Secretary of State, Salem, Oregon, 1958.

Oregon. Oregon Blue Book 1955. Compiled by Earl T. Newbry, Secretary of State, Salem, Oregon, 1955.

Schramm, Wilbur and White, David M. "Age, Education and Economic Status as Factors in Newspaper Reading." Journal ism Quarterly, Vol . 26 (1949), 155-157.

Stanton, Frank. "Notes on the Validity of Mail Questionnaire Returns." Journal of Applied Psychology, Vol. 23 (1939), 95-104.

Star, Shirley A. and Hughes, Helen MacGill. "Report on an Educational Campaign: The Cincinnati Plan for the United Nations." American Journal of Sociology, Vol. 55 (1950), 389-400.

Swanson, David L. "The New Politics Meets the O1d Rhetoric: New Directions in Communication Research." The Quarterly Journal of Speech, Vo1. 58 (February, 1972), 31-40.

\section{Newspapers}

Argus. Hillsboro, Oregon: January 6, 10, 1972.

Capital Journal. Salem, Oregon: December 21, 1971; January 15, 19, 1972.

Central Oregonian. Prineville, Oregon: December 23, 1971.

Columbia Press. Astoria, Oregon: December 16, 1971.

Daily Astorian. Astoria, Oregon: January 5, 12, 1972.

Daily Courier. Grants Pass, Oregon: January 3, 4, 13, 1972.

Daily Tidings. Ashland, Oregon: January 13, 1972.

Democrat-Herald. Albany, Oregon: December 27, 1971; January 5, 11, 1972 .

Democrat Herald. Baker, Oregon: December 17, 1971.

East Oregonian. Pendleton, Oregon: January 11, 13, 1972.

Gazette-Times. Corvallis, Oregon: December 22, 23, 1971.

Greater Oregon. Albany, Oregon: January 14, 1972 .

Herald and News. Klamath Falls, Oregon. January 7, 11, 16, 1972.

La Grande Observer. LaGrande, Oregon: January 11, 1972. 
Lake County Examiner. Lake-View, Oregon: December 16, 1971.

Mail Tribune. Medford, Oregon: January 10, 16, 1972.

Myrtle Creek Mail. Myrtle Creek, Oregon: December 30, 1971.

North Coast Eagle-Times. Wheeler, Oregon. January 6, 1972.

Oregonian. Portland, Oregon: December 28, 1971; January 4, 7, $8,11,12,13,14,17,18,1972$.

Oregon Journal. Portl and, Oregon: December 28, 1971 ; January 4, 7, $8,11,12,13,14,17,18,1972$.

Oregon Statesman. Salem, Oregon: January 21, 1972.

Rainier Review. Rainier, Oregon: December 23, 1971.

Register-Guard. Eugene, Oregon: January 4, 8, 9, 16, 21, 197.

Siskiyou. Southern Oregon College, Ashland, Oregon: January 14, 1972.

Siuslaw News. Florence, Oregon: January 6, 1972.

Spokesman. Pendleton, Oregon: January 18, 1972.

The World. Coos Bay, Oregon: December 27, 1971.

Publ ished Reports

Government Relations Department. Directory: Fifty-Sixth Legislative Assembly of the State of Oregon: 1971-73. Oregon Education Association. Tigard, Oregon, 1971 .

Joint Finance Committee of Oregon School Boards Association; Association of Oregon Counties; League of Oregon Cities. "A State Wide Income Tax for Oregon: Local Governments and Its Distribution to Cities, Counties and School Districts." Bureau of Governmental Research and Service, University of Oregon, 1970.

Oregon, State of. Official Abstract of Votes: Special Election 1972. Compiled and published by Clay Myers, Secretary of State. Salem, Oregon, May 1, 1972.

Oregon, State of. Voters' Pamphlet: Primary Nominating Election, May 24, 1966. Compiled and published by Tom McCall, Secretary of State.

Oregon, State of. Voters' Pamphlet: Special Election, June 3, 1969. Compiled and published by Clay Myers, Secretary of State. Salem, Oregon, 1969. 
Oregon, State of. Voters' Pamphlet: Special Election, January 18, 1972. Compiled and published by Clay Myers, Secretary of State. Salem, Oregon, 1972 .

"Public Opinion and Taxes." Advisory Commission on Intergovernmental Relations. Washington, D.C., May, 1972.

U.S. Bureau of Census. Characteristics of the Population: Oregon, 1950, Part 37, Vol. II. U.S. Government Printing Office, Washington, D.C., 1952 .

U.S. Bureau of Census. Characteristics of the Population: Oregon, 1970. U.S. Government Printing Office, Washington, D.C., 1972.

Unpublished Reports

"Campaign Contributions and Expenditures, Special Election, January 18, 1972." Secretary of State, Elections Division. Salem, Oregon, 1972. (Original)

Bardsley and Haslacker, Inc. "Property Tax Limitation Measure." Public Opinion Survey. Portland, Oregon, Mid-October, 1968. (Zeroxed)

Kennedy, Richard L. and Associates. "Attitudes Toward the January 18, 1972 Special Election on Increasing the Cigarette Tax." Public Opinion Survey. Eugene, Oregon, December, 1971. (Zeroxed)

Oregon Bducation Association. "Legislative Memo." Department of Legislative Affairs. Tigard, Oregon, November 29, 1971. (Zeroxed)

Vernstrom, Roy N. "The Politics of Taxation." Unpublished M.S. paper, Portland State University. Portland, Oregon, 1968. (Carbon)

\section{Interviews}

Anala, George. Publisher, Oregon Tax Research, Portland, Oregon. Interview by phone, July 17, 1972 .

Davis, Brad. Free-lance campaign consultant, Portland, Oregon. Interview in Portland, Oregon, February, 1972.

Davis, Robert. Executive Assistant to Governor Tom McCa11, Salem, Oregon. Interview in Salem, Oregon, February, 1972.

Danielson, John. Director of Legislative Affairs, Oregon Education Association, Tigard, Oregon. Interview in Pórtland, Oregon, March, 1972. 
Day, L.B. Director, Department of Environmental Quality, State of Oregon, Portland, Oregon. Interview by phone, July, 1972.

Diel, George. Director of Portl and Chancellor's Office, Director of Public Affairs, State Board of Higher Education, Portland, Oregon. Interview in Portland, Oregon, April, 1972.

Enright, Thomas. Executive Secretary, Oregon State Employees Association, Salem, Oregon. Interview in Salem, Oregon, March, 1972.

Hallock, Ted. Owner, Ted Hallock Public Relations, Inc., Portland, Oregon. Interview in Portland, Oregon, July, 1972.

Hawkinson, John. President, Clackamus Community College, Oregon City, Oregon. Interview by phone, July, 1972.

Jones, Clarence. Director, Oregon Economic Opportunity Division, Department of Human Resources, State of Oregon, Salem, Oregon. Interview in Salem, Oregon, April, 1972.

Kennedy, Richard. Owner, Richard Kennedy and Associates, Inc., Eugene, Oregon. Interview by phone, July, 1972 .

King, Alton. Executive Secretary to University of Oregon Student Body President, Eugene, Oregon. Interview in Portl and, Oregon, July, 1972.

Lesh, William. Associated Oregon Industries, Portland, Oregon. Interview by phone, August, 1972 .

Meaney, Patrick. Assistant Executive Secretary, Oregon Education Association, Tigard, Oregon Interview by phone, July, 1972.

Post, Wil. Assistant to President George McVicar, Oregon State University, Corvallis, Oregon. Interview in Corvallis, Oregon, June, 1972.

Roberts, Frank. Representative, Oregon House of Representatives, Portland, Oregon. Interview by phone, July, 1972 .

Shephard, Ruth. Private citizen working with State Council of Senior Citizens, Eugene, Oregon. Interview by phone, July, 1972.

Tanzer, Jacob. Director, Department of Human Resources, State of Oregon, Salem, Oregon. Interview in Salem, Oregon, April, 1972.

Thompson, Jack. Assistant Secretary of State, State of Oregon, Salem, Oregon Interview in Salem, Oregon, March, 1972.

\section{Correspondence Cited}

Boe, Jason State Senator, Douglas County. Letter dated June 24, 1972. 
Cropsey, Myron. Past president, OSEA Chapter 72, Corvallis, Oregon. Letter dated July 11, 1972.

Davis, Robert. Assistant to the Governor, State of Oregon, Salem, Oregon. Letter dated July 14, 1972.

Fadley, Edward. State Senator, Lane County. Letter dated June 14, 1972.

Friends of Higher Education, Portland, Oregon. Letter obtained from George Diel, Chancellor's Portl and Office, dated January 6, 1972.

Hughes, Marion State Council of Senior Citizens, Salem, Oregon. Letter dated July 18, 1972 .

Ingalls, Robert. Editor, Gazette-Times, Corvallis, Oregon. Letter dated July 15, 1972 .

Jones, Donald. Executive Secretary, League of Oregon Cities, Salem, Oregon. Letter dated July 19, 1972.

Lesh, Bill. Association of Oregon Industries, Portland, Oregon Letter dated July 14, 1972 .

McKay, Floyd. KGW-TV News Analyst, Portland, Oregon. Letter dated July 6,1972 .

Myers, Clay. Secretary of State, State of Oregon, Salem, Oregon. Notice sent to county elections officers, September 8, 1968. Obtained from Roy Vernstrom.

Nelson, Jack. President, Oregon Council of Senior Citizens. Letter dated August 7, 1972; Letter from Nel son to Alton King, November 22, 1971, obtained from King.

Orrich, P Jerry. Executive Secretary, Association of Oregon Counties, Salem, Oregon. Letter dated July 18, 1972.

Rigby, Thomas. Executive Secretary, Oregon School Boards Association, Eugene, Oregon. Letter dated July 29, 1972 .

Ripper, Jack. State Representative, Coos County. Letter dated July 14, 1972.

Scanlon, Thomas. Director, Publ ic Information, AFL-CIO, Salem, Oregon. Letter dated June 18, 1972.

Wilkinson, Ronald. Student Body President, Oregon State University, Corvallis, Oregon. Letter dated July 8, 1972. 
Bulletins

Association of Oregon Industries. Salem, Oregon, December 28, 1971.

Oregon State Employees Association News. Special Section. Salem, Oregon, January, 1972

Your Taxes: Oregon Tax Research. Vol. 37 Portland, Oregon, January, 1972 .

Press Releases

Nelson, Jack President, Oregon State Council of Senior Citizens. Issued in Salem, Oregon, November 10, 1971. (Mimeographed)

Snyder, Ruth. State Council of Senior Citizens. Issued at Celeste Campbell Center, in conjunction with Seniors-Youth Lane Coalition, December 15, 1971. (Mimeographed)

Tanzer, Jacob. Director, Department of Human Resources, State of Oregon. Issued in Salem from remarks to Washington County Publ ic Affairs Forum, Beaverton, Oregon, December 14, 1971. (Mimeographed) 
APPENDICES 
APPENDIX A

TAX PROPOSAL VOTING RECOPD

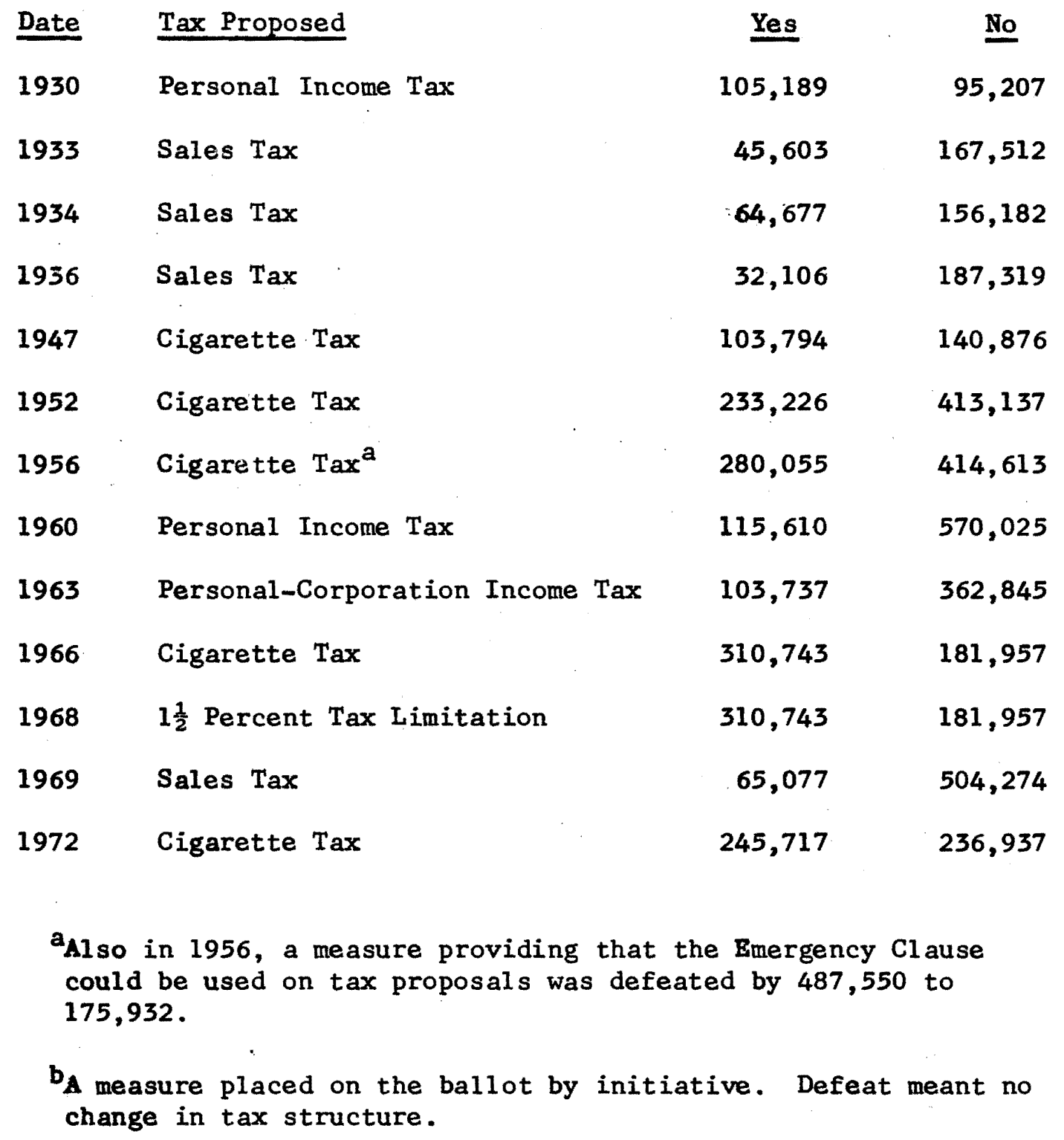

Source: Oregon Blue Book 1955; Oregon Blue Book 1971-72. 


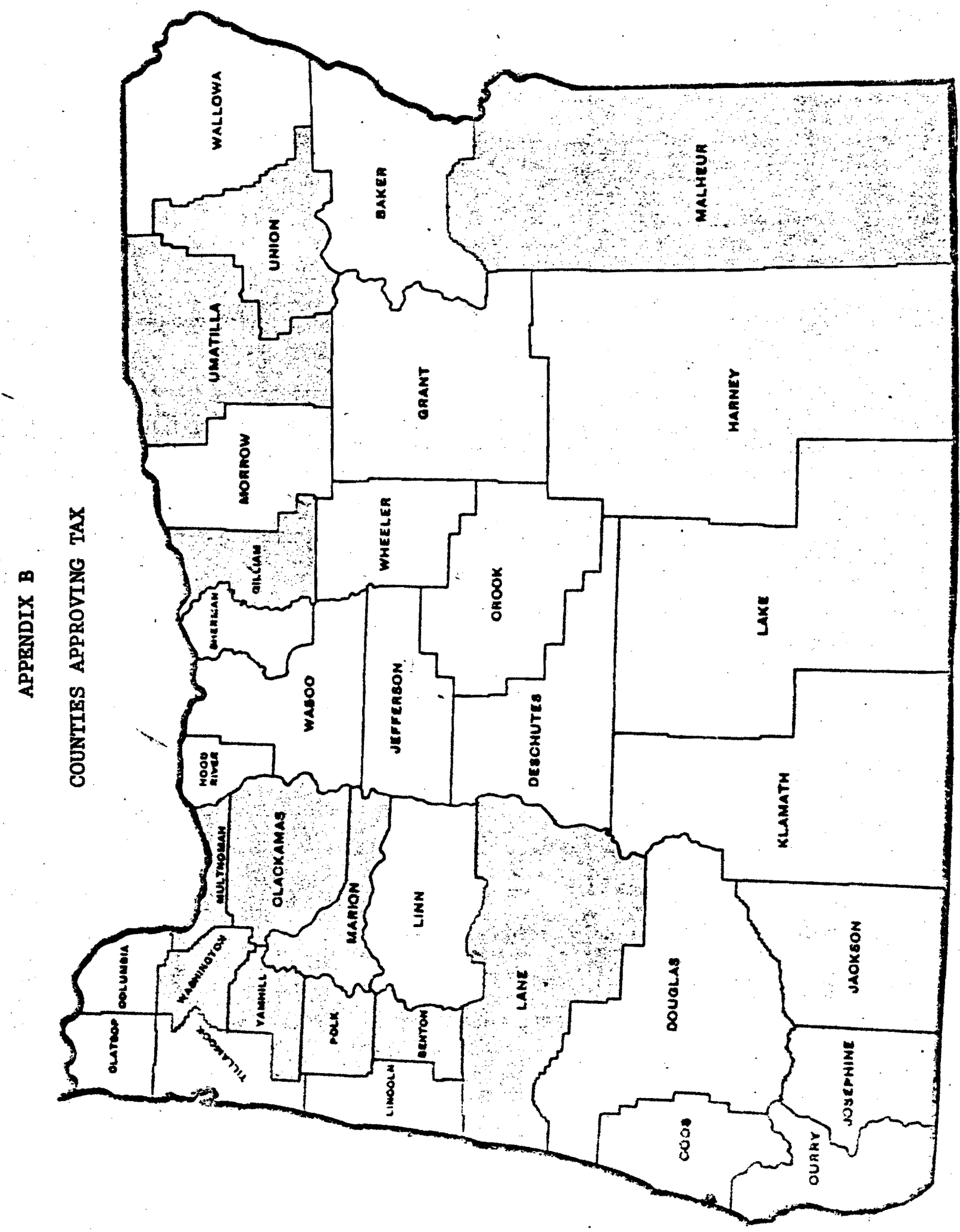


APPENDIX C

JANUARY 18, 1972, SPECIAL ELECTION SUMMARY OF COUNTY VOTE

\begin{tabular}{|c|c|c|c|}
\hline Cainty & & Yes & No \\
\hline Baker & & 1,393 & 1,680 \\
\hline Benton & & 10,551 & 4,507 \\
\hline Cl ackamas & & 21,118 & 19,497 \\
\hline Cl atsop & & 2,843 & 4,239 \\
\hline Columbia & & 2,952 & 3,852 \\
\hline Coos & & 5,661 & 7,925 \\
\hline Crook & & 1,010 & 1,405 \\
\hline Curry & & 1,116 & 1,657 \\
\hline Deschutes & & 3,491 & 3,749 \\
\hline Douglas & & 5,898 & 9,223 \\
\hline Gilliam & & 319 & 311 \\
\hline Grant & & 681 & 907 \\
\hline Harney & & 674 & 824 \\
\hline Hood River & & 1,558 & 1,566 \\
\hline Jackson & & 7,807 & 9,807 \\
\hline Jefferson & & 887 & 1,091 \\
\hline Joseph ine & & 2,774 & 5,180 \\
\hline Klamath & & 3,634 & 5,829 \\
\hline Lake & & 503 & 998 \\
\hline Lane & & 24,989 & 24,140 \\
\hline Lincoln & & 2,642 & 3,422 \\
\hline Linn & & 7,033 & 9,257 \\
\hline Malheur & & 2,132 & 1,442 \\
\hline Marion & & 20,024 & 15,478 \\
\hline Morrow & & 537 & 603 \\
\hline Multnomah & & 68,342 & 59,842 \\
\hline Polk & & 5,238 & 4,105 \\
\hline She rman & & 284 & 403 \\
\hline Till amook & & 2,016 & 2,602 \\
\hline Umatilla & & 4,690 & 4,622 \\
\hline Union & & 2,650 & 2,076 \\
\hline Wallowa & & 785 & 815 \\
\hline Wasco & & 2,569 & 2,611 \\
\hline Washington & & 21,922 & 16,762 \\
\hline Wheeler & & 199 & 314 \\
\hline Yamhill & & 4,795 & 4,196 \\
\hline & Totals & 245,717 & 236,937 \\
\hline
\end{tabular}

Source: Official Abstract of Votes Special Election 1972. 
APPENDIX D-1

\section{PUBLIC OPINION SURVEY QUESTIONNAIRES \\ VOTEKJ \\ SECTION I}

1. How often do you vote in state-wide elections?
(1) every election
(2) most elections
(3) some elections
(4) few elections
(5) rarely

2. Would you have been affected if the cigarette tax measure had been defeated?

(1) yes

(2) no

(3) uncertain

If you answer was yes, please indicate how it would have affected you.

3. If you voted FOR the cigarette tax measure, check the two reasons most important to you.

(1) continued property tax relief.

(2) possibility of cuts to state agencies if new revenue was unavailable.

(3) possibility or: increased college tuition if new revenue was unavailable.

(4) possibility of cuts to public schools.

(5) out-of-state tobacco interests would benefit more than Oregon.

(6) because smoking is dangerous anyway.

(7) other.

4. If you voted AGAINST the cigarette tax measure, check the two reasons most important to you.

(1) the tax is regressive and hurts a special group.

(2) the tax is the same as a sales tax of which I disapprove.

(3) cigarettes al ready cost too much.

(4) taxes should not be increased until government learns economy.

(5) all taxes are too high.

(6) property tax relief is not guaranteed by the tax measure.

(7) other.

5. How did you learn about the measure?

(1) television or radio advertising.

(2) the Voters' Pamphlet.

(3) public speeches or debates.

(4) regular news reports.

(5) organization newsletters or bulletins. 
(6) talking to friends or relatives.

(7) other.

6. What information sources were the most important to you in your decision on how to vote?

(1) public meetings in your area.

(2) newsletters from organizations.

(3) newspaper reports.

(4) newspaper editorials.

(5) television or radio advertising.

(6) conversations with friends or neighbors.

(7) other.

7. Other than the information sources already mentioned, what source was most important in your decision on how to vote?

(1) husband or wife.

(2) one or both parents.

(3) neighbor or friend.

(4) community leader.

(5) church affiliated leader.

(6) community official.

(7) public official (on a state level)

8. Many groups worked in the cigarette tax campaign. Please indicate which group you think had the most influence on the outcome of the election.

(1) senior citizens.

(2) college students.

(3) teachers.

(4) state employees.

(5) state legislators.

(6) businesses.

(7) governor's office.

(8) higher education.

(9) other.

9. Were you contacted personally by anyone from a group 1 isted above?

(1) yes.

(2) no

10. In your opinion, were the opponents of the cigarette tax measure in your area clear in explaining important issues?
(1) extremely clear.
(2) somewhat clear.
(3) not at all clear.

11. In your opinion, were those supporting the cigarette tax measure in your area clear in explaining important issues?
(1) extremely clear.
(2) somewhat clear.
(3) not at all clear.

12. Are you a member of a professional association or union?
(1) yes.
(2) no.
If yes, please name the organization:
If no, please skip to Section II. 
13. How often do you attend association or union meetings in comparison with others in the organization?
(1) regularly.
(2) frequently.
(3) occasionally.
(4) rarely.
(5) never.

14. How often do you read the organization's newsletter or bulletin?
(1) regul arly.
(2) frequently.
(3) occasionally.
(4) rarely.
(5) never.

15. Was your association or union involved in the cigarette tax campaign?

(1) yes.

(2) no.

(3) uncertain.

16. If your answer to the above question was yes, please indicate the functions your organization performed in the campaign.

\section{SECTION II}

1. How often do you view television?
(1) most of the time.
(4) news only.
(2) daytime only.
(5) rarely watch television.
(3) evenings only.
(6) never watch television.

2. How often do you attend public debates or speeches of a political nature?
(1) regularly.
(2) frequently.
(3) rarely.
(4) never.

3. How often do you 1 isten to political advertising prior to an election?
(1) regularly.
(2) frequently.
(3) rarely.
(4) never.

4. How frequently do you read the newspaper?
(1) daily.
(2) most days.
(3) once a week.
(4) several times a week.
(5) less than once a week.
(6) never.

5. How often do you talk with friemds, neighbors or business associates about political issues or state ballot measures such as the cigarette tax?
(1) often.
(2) occasionally.
(3). rarely.
(4) never.

6. Please indicate your age:

7. Your sex:

8. occupation:

9. grades of school completed: 
10. Your political party:

11. Type of living community:

12. Your approximate income:

\section{LEADERS *}

1. What part did your organization or group play in the recent cigarette tax campaign?
(1) a major role.
(2) a minor role.

2. How would you characterize your organization or group's role in the total campaign?

(1) as legitimizers of the measure on a state level.

(2) as legitimizers of the measure on a local level.

(3) initiating activity on a state level.

(4) initiating activity on a local level.

(5) initiating activity within your organization.

(6) information source to the general public.

(7) information source to your membership.

3. What were some of the tasks your organization or group performed in the campaign?
(1) fund raising.
(2) mailings to your members.
(3) mailings to general public.
(4) public statements quoted by the press.
(5) public speaking appearances.
(6) inter-organizational coordination.
(7) recruiting and/or organizing manpower.
(8) other.

4. How did your organization become involved in the cigarette tax campaign?

(1) personal contact by another involved individual or group.

(2) decision made independently by your organization or group.

(3) decision made independently by your organization leadership.

5. If the tax measure had been defeated, what would have been the projected fiscal impact on your organization or group?
(1) considerable.
(3) very little.
(2) slight.
(4) none at all.

6. If your answer to the last question was positive, would your organization have been involved if there had not been the possibility of major fiscal impact?
(1) yes
(2) no
(3) uncertain

7. In your district or county, which communication channels 1 isted below was the most important in the election outcome?
(1) television
(2) radio.
(3) newspaper advertising.
(5) public speeches.
(6) door-to-door campaigning.
(4) news reports.
(7) mailings to voters.
(8) editorial comment. 
8. In your county or district, which communication channels were used for getting information to the voters?
(1) television.
(2) radio
(3) newspaper advertising.
(4) news reports.
(5) public speeches.
(6) door-to-door campaigning.
(7) mailings to voters.
(8) editorial comment.

9. What impact do you think the following groups had in the campaign on the state wide level?
(1) higher education.
(2) public employees.
(5) senior citizens.
(3) public education.
(4) businesses.
(6) youth.
(7) organized labor.
(8) other.

10. How would you rate the organization of the cigarette tax campaign on a state wide level as compared with other campaigns on state tax measures?

(1) very well coordinated.

(2) poorly/ coordinated.

(3) cannot compare.

11. How do you rate the clarity of the proponents of the measure in explaining important is sues?
(1) extremely clear.
(2) somewhat clear.
(3) not clear.

12. How do you rate the clarity of the opponents of the measure in explaining important issues?

(1) extremely clear. (2) somewhat clear. (3) not clear.

13. Of the issues selected, which had the most impact in persuading the members of your organization or group to vote in favor of the tax?

(1) property tax relief.

(2) cuts to state agencies.

(3) increased college tuition.

(4) against out-of-state tobacco interests.

(5) smoking is dangerous.

(6) state support to publ ic education cuts.

(7) other.

14. Of the issues selected, which had the most impact in persuading the members of your organization or group to vote against the tax?

(1) regressive tax.

(2) similarity to a sales tax.

(3) all taxes too high.

(4) high cost of cigarettes.

(5) danger to property tax relief.

(6) other.

* Questionnaires mailed to legislators substituted the wording, "your organization or group," for "you," or "your constitutents." 


\section{APPENDIX D-2 \\ INTERVIEW QUESTIONS TO \\ INELUENT LALS*}

1. How did you or your organization become involved in the campaign?

2. What was the extent of your involvement?

3. In your judgment, would you say that the campaign was well planned? Were the most important issues used? Were appropriate campaign techniques utilized?

4. What was the most important factor responsible for the outcome of the campaign? (Campaign themes, choice of communication channels, success in educating the public, etc.)

5. What was the impact of the media used?

6. Which interest groups active in the campaign had the most impact on the final vote? Why?

7. Can you identify key influentials who made public statements supporting the ballot measure, and can you judge the impact of their public stance?

8. How does this campaign effort compare with previous campaigns you have been involved in? What are the similarities? The differences?

9. Would another campaign run in the same way succeed? Why or why not?

10. What was the attitude of your membership or constitutency toward the issues selected? Why do you think they voted as they did? Did your activity in the campaign have any influence on their vote? Why?

* Includes major questions posed to influentials but not necessarily in this order. Spontaneous comments were solicited whenever possible. 


\begin{abstract}
APPENDIX E
SAMPLE OF PRO-TAX CAMPAIGN COMMITTEE FLIERS
\end{abstract}

WHAT MIGHT HAPPEN TO THE POOR (MEN, WOMEN AND KIDS) . .

if the 5d-a-pack Cigarette Tax doesn't pass on January 18 ?

The answer is obvious: THE POOR WILL BE HIT SO HARD, IT WILL MEAN

A "LIVING HELL."

If it's been touch "surviving" on only $80 \%$ of what is necessary to Iive on, IMAGINE LOSING ANOTHER \$2,903,000:

AND IT COULD GET A LOT WORSE -- WITHOUT ANY PROMISE OF GETTING BETTER.

"SUPPORT MONIES" -- that's the official phrase for food and shoes and clothes -- MIGHT BE CUT A LOT MORE THAN JUST $\$ 9,903,000$-- LIKE ' $\$ 17,200,000::$ :

OLD AGE ASSISTANCE COULD BE WIPED OUT -- GOING FROM $\$ 63.69$ PER MONTH TO $\$ 2.69$ :

AID TO DISABLED COULD BE CUT TO \$27 82 PER MONTH:

AID TO DEPENDENT CHILDREN COULD BE SLASHED BY \$92 -FOR A FAMILY OF FOUR:

THE ABUNDANT FOOD OR FOOD STAMP PROGRAMS COULD BE REDUCED TO $39 \%$ OF THE STANDARD NECESSARY TO SIMPLY SURVIVE :

And one more point ...

IF THE $\$ 17,200,000$ WERE TAKEN AWAY, YOU COULD AISO LOSE $\$ 21,700,000$ IN FEDERAL HELP:

We know your Christmas and New Year will be a tough, miserable and painful time as it is.

BUT YOU CANNOT SIT ON YOUR HANDS AND LET THE CANCEROUS CIGARETTE LOBBY DBFEAT THE CIGARETTE TAX -- SO THAT YOU CAN STARVE A LITTLE BIT MORE.

TALK TO YOUR FRIENDS. MAKE THEM KNOW WHAT COULD HAPPEN.

And. - BE SURE THAT YOU AND YOUR FRIENDS VOTE ON TUESDAY, JANUARY 18. WOTE "YES" ON THE CIGARETTE TAX. 
WHAT MIGHT HAPPEN TO OREGON'S HIGHER EDUCATION --

if the 5c-a-pack Cigarette Tax failes to pass in the January 18

State-wide Special Election?

FACT: Governor McCall has stated that he WILL CALL ANOTHER SPECIAL SESSION SHOULD THE CIGARETTE TAX FAIL.

FACT: Governor MCCall has also stated that he WILL NOT ALLOW FURTHER "ACROSS-THE-BOARD" CUTS ON OUR STATE BUDGET. (We've already cut more than $\$ 36,000,000$ from the originally proposed budget.)

FACT: "SELECTIVE PROGRAM CUTS AND/OR TAX INCREASES WILL HAVE TO BE MADE (should the Cigarette Tax fail) to both balance the State Budget (a Constitutional requirement ${ }^{1}$ ) and provide the necessary monies to salvage priority State services and programs.

FACT: Eithe : of these "SELECTIVE" programs could be DIRECTED AT OREGON'S HIGHER EDUCATION:

FACT: If the ENTIRE $\$ 17,200,000$ expected to be raised by the Cigarette Tax were taken from the Higher Education instruction budget, THE LOSS OF MONEY COULD BE RECOVERED BY A NEARLY DOUBLED INCREASE IN TUITIONS FOR RESTDENT UNDERGRADUATE STUDENTS FOR THE 1972-73 SCHOOL YEAR.

(Tuitions would have to be raised $\$ 344$ over the present $\$ 378$-RAISING TUITIONS TO \$722 PER YEAR:)

EACT: If it was determined that this loss of State revenue should be recovered by REDUCING TEACHING FACULTY in the State System of Higher Educat ion, IT WOULD REQUIRE A REDUCTION OF 1, 140 TEACHING FACULTY MEMBERS FOR THE 1972-73 SCHOOL YEAR.

THIS REDUCTION OF STAFF WOULD BE EQUAL TO THE ENTIRE TEACHING STAFF OF THE UNI VERSITY OF OREGON . . .

\footnotetext{
Article XI, Section 7: The Legislative Assembly shall not lend the credit of the State nor in any manner create any debt or liabilities which snall . . exceed the sum of $\$ 50,000$. ."
}

Source: Citizens Against Raising Property Taxes, 300 Jackson Tower, Portland, Oregon. Bill Gilbert, Tre asurer.

Note: The first page of each flier is reproduced here in its entirety. 


\section{APPENDIX F}

TABLES REFERRED TO IN THE TEXT

Table F-1

IRELATION OF AGE TO YES-NO VOTE:

\begin{tabular}{|c|c|c|c|c|c|c|c|c|}
\hline & \multicolumn{4}{|c|}{ BENTON } & \multicolumn{4}{|c|}{ DOUGLAS } \\
\hline & \multicolumn{2}{|c|}{ YES } & \multicolumn{2}{|c|}{ NO } & \multicolumn{2}{|c|}{ YES } & \multicolumn{2}{|c|}{ No } \\
\hline & $\mathbf{N}$ & PCNT & $\mathrm{N}$ & PCNT & $\mathrm{N}$ & PCNT & $\mathrm{N}$ & PCNT \\
\hline $18-21$ & 3 & $100 \%$ & 0 & $0 \%$ & 1 & $100 \%$ & 0 & $0 \%$ \\
\hline $22-29$ & 8 & 89 & 1 & 11 & 8 & 89 & 1 & 11 \\
\hline $30-39$ & 12 & 60 & 8 & 40 & 3 & 30 & 7 & 70 \\
\hline $40-49$ & 8 & 53 & 7 & 47 & 4 & 24 & 13 & 76 \\
\hline $50-59$ & 9 & 75 & 3 & 25 & 8 & 62 & 5 & 38 \\
\hline $60=$ & 8 & 73 & 3 & 26 & 6 & 44 & 9 & 56 \\
\hline
\end{tabular}

Table F-2

RELATION OF SEX TO YES-NO VOTE

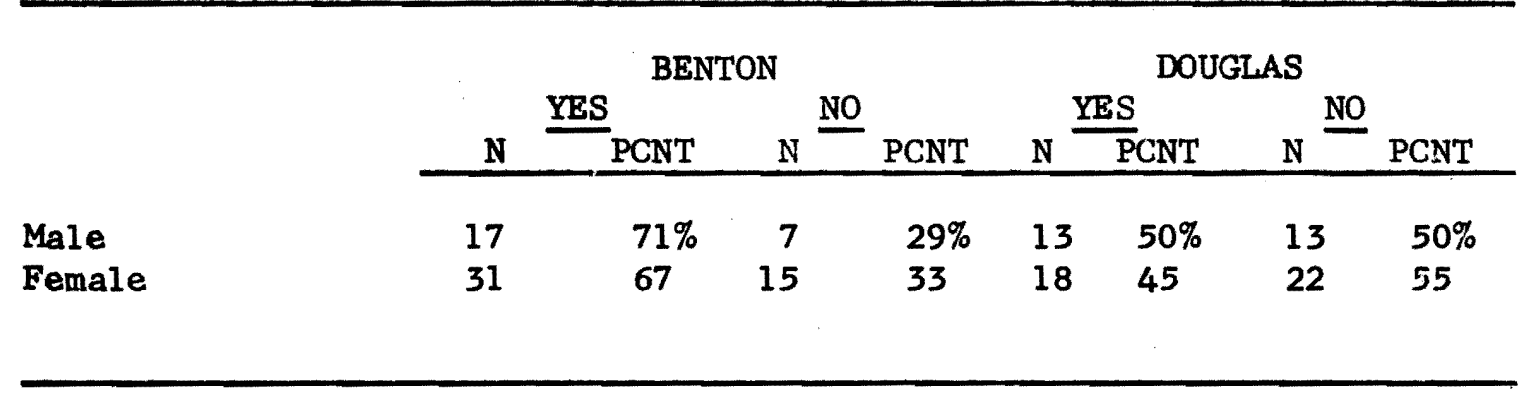

Table F-3

RELATION OF RESIDENCE TO YES-NO WTE

\begin{tabular}{|c|c|c|c|c|c|c|c|c|}
\hline & \multicolumn{4}{|c|}{ BENTON } & \multicolumn{4}{|c|}{ DOUGLAS } \\
\hline & \multicolumn{2}{|c|}{ YES } & \multicolumn{2}{|c|}{ No } & \multicolumn{2}{|c|}{ YES } & \multicolumn{2}{|c|}{ No } \\
\hline & $\mathrm{N}$ & PCNT & $\mathrm{N}$ & PCNT & $\mathrm{N}$ & PCNT & $\mathrm{N}$ & PCNT \\
\hline Metropolitan & 2 & $67 \%$ & 1 & $33 \%$ & 0 & $0 \%$ & 2 & $100 \%$ \\
\hline Suburb & 4 & 80 & 1 & 20 & 3 & 50 & 3 & 50 \\
\hline City or Town & 37 & 73 & 14 & 27 & 20 & 47 & 23 & 53 \\
\hline Open Country & 4 & 40 & 6 & 60 & 6 & 43 & 8 & 57 \\
\hline
\end{tabular}


Table F-4

RELATION OF EDUCATION TO YES-NO VOTE

\begin{tabular}{|c|c|c|c|c|c|c|c|c|}
\hline \multirow[t]{3}{*}{ : } & \multicolumn{4}{|c|}{ BENTON } & \multicolumn{4}{|c|}{ DOUGLAS } \\
\hline & \multicolumn{2}{|c|}{ YES } & \multicolumn{2}{|c|}{ NO } & \multicolumn{2}{|c|}{ YES } & \multicolumn{2}{|c|}{ No } \\
\hline & $\mathbf{N}$ & PCNT & $\mathrm{N}$ & PCNT & $N^{-}$ & PCNT & $\mathbf{N}$ & PCNT \\
\hline Some High School & 1 & $25 \%$ & 3 & $75 \%$ & 2 & $40 \%$ & 3 & $60 \%$ \\
\hline High School & 10 & 59 & 7 & 41 & 8 & 35 & 15 & 65 \\
\hline Some College & 11 & 65 & 6 & 35 & 7 & 39 & 11 & 61 \\
\hline College & 10 & 77 & 3 & 23 & 7 & 64 & 4 & 36 \\
\hline Post College & 15 & 83 & 3 & 17 & 5 & 83 & 1 & 17 \\
\hline
\end{tabular}

Table F-5

RELATION OF OCCUPATION TO YES-NO VOTE

\begin{tabular}{|c|c|c|c|c|c|c|c|c|}
\hline & \multicolumn{4}{|c|}{ BENTON } & \multicolumn{4}{|c|}{ DOUGLAS } \\
\hline & \multicolumn{2}{|c|}{ YBS } & \multicolumn{2}{|c|}{ No } & \multicolumn{2}{|c|}{ YES } & \multicolumn{2}{|c|}{ No } \\
\hline & $\mathbf{N}$ & $\mathrm{PCNT}$ & $\mathrm{N}$ & PCNT & $\mathrm{N}^{\circ}$ & PCNT & $\mathrm{N}$ & PCNT \\
\hline Farm Operator & 0 & $0 \%$ & 0 & $0 \%$ & 1 & $50 \%$ & 1 & $50 \%$ \\
\hline Housewife & 22 & 79 & 6 & 21 & 8 & 40 & 12 & 60 \\
\hline Professional-Tchn1 & 13 & 59 & 9 & 41 & 13 & 57 & 10 & 43 \\
\hline Business-Mngrl & 3 & 43 & 4 & 57 & 3 & 38 & 5 & 63 \\
\hline Retired & 4 & 57 & 3 & 43 & 3 & 43 & 4 & 57 \\
\hline Unemployed & 1 & 100 & 0 & 0 & 0 & 0 & 0 & 0 \\
\hline Clerical-Sales & 1 & 100 & 0 & 0 & 1 & 50 & 1 & 50 \\
\hline
\end{tabular}

Table F-6

RELATION OF INCOME TO YES-NO VOTE

\begin{tabular}{|c|c|c|c|c|c|c|c|c|}
\hline & \multicolumn{4}{|c|}{ BENTON } & \multicolumn{4}{|c|}{ DOUGLAS } \\
\hline & \multicolumn{2}{|c|}{ YES } & \multicolumn{2}{|c|}{ No } & \multicolumn{2}{|c|}{ YES } & \multicolumn{2}{|c|}{ No } \\
\hline & $\mathbf{N}$ & PCNT & $\mathrm{N}$ & PCNT & $\mathrm{N}$ & PCNT & $\mathrm{N}$ & PCNT \\
\hline Under $\$ 5,000$ & 11 & $65 \%$ & 6 & $35 \%$ & 5 & $56 \%$ & 4 & $44 \%$ \\
\hline$\$ 5,000-9,999$ & 9 & 75 & 3 & 25 & 11 & 52 & 10 & 48 \\
\hline$\$ 10,000-14,999$ & 14 & 67 & 7 & 33 & 12 & 57 & 9 & 43 \\
\hline$\$ 15,000-25,000$ & 12 & 80 & 3 & 20 & 3 & 23 & 10 & 77 \\
\hline$\$ 26,000$-PLUS & 2 & 67 & 1 & 33 & 0 & 0 & 2 & 100 \\
\hline
\end{tabular}


Table F-7

RELATION OF ORGANIZATION MEMBERSHIP TO YES-NO VOTE

Member

Non-member

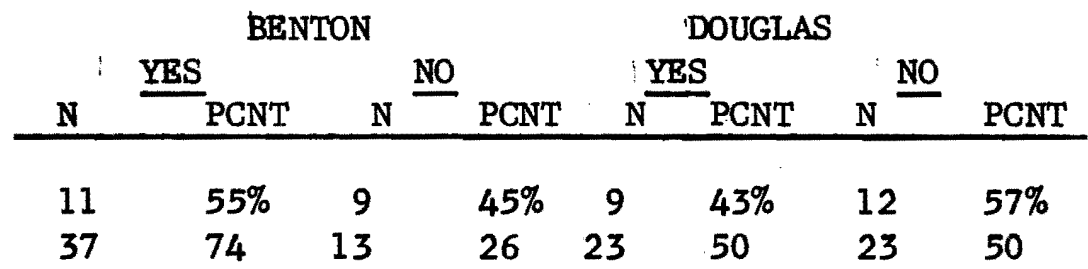




\section{Table F-8 \\ ORGANIZATIONAL LEADER INVOLVEMENT}

HOW DID YOU BECOME INVOLVED IN THE CAMPAIGN?

Response

Number

Personal contact by another individual or group: 4

Decision made by organization independently: 6

Decision:made by organizational leadership independently: 4

WHAT WAS THE EXPECTED FISCAL IMPACT ON YOUR ORGANIZATION OR GROUP?

Response

Number

Considerable

Slight

Very little

None at all

11

1

1

2

WOULD YOUR ORGANIZATION HAVE BEEN INVOLVED IE

THERE HAD NOT BEEN THE POSSIBILITY OF MAJOR FISCAL IMPACT?

Response

Number

Yes

No 3

Uncertain 